Prepared in cooperation with the City of Bainbridge Island

\title{
Conceptual Model and Numerical Simulation of the Groundwater-Flow System of Bainbridge Island, Washington
}

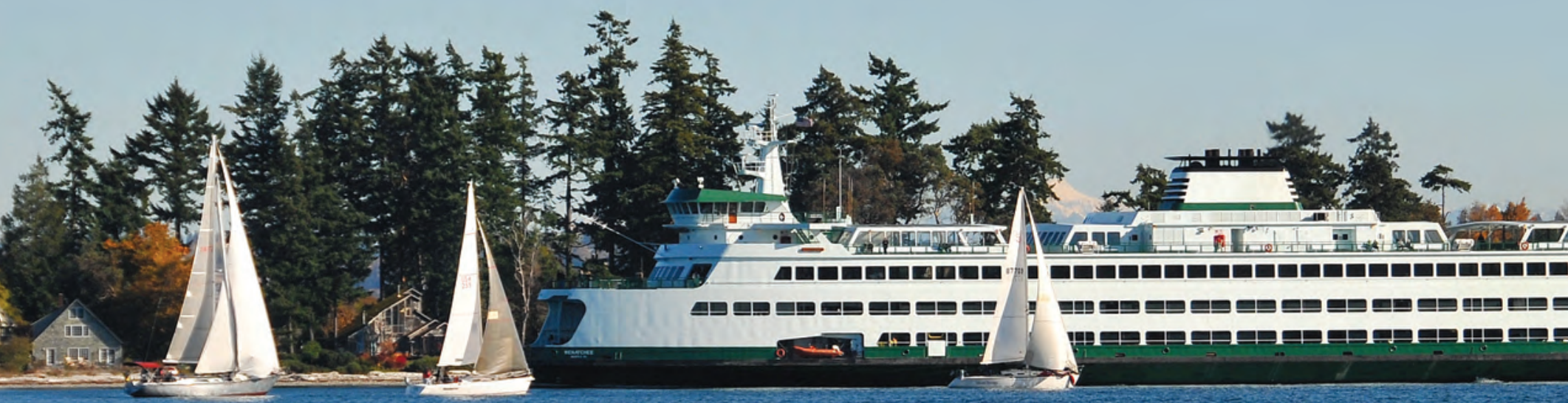

Scientific Investigations Report 2011-5021

U.S. Department of the Interior

U.S. Geological Survey 
Cover: Photograph of a ferry landing at Bainbridge Island, Washington. (Photograph taken by Mitchell Lant, private citizen, date unknown.) 


\section{Conceptual Model and Numerical Simulation of the Groundwater-Flow System of Bainbridge Island, Washington}

By Lonna M. Frans, Matthew P. Bachmann, Steve S. Sumioka, and

Theresa D. Olsen

Prepared in cooperation with the City of Bainbridge Island

Scientific Investigations Report 2011-5021 


\title{
U.S. Department of the Interior \\ KEN SALAZAR, Secretary \\ U.S. Geological Survey \\ Marcia K. McNutt, Director
}

\author{
U.S. Geological Survey, Reston, Virginia: 2011
}

For more information on the USGS - the Federal source for science about the Earth, its natural and living resources, natural hazards, and the environment, visit http://www.usgs.gov or call 1-888-ASK-USGS.

For an overview of USGS information products, including maps, imagery, and publications, visit http://www.usgs.gov/pubprod

To order this and other USGS information products, visit http://store.usgs.gov

Any use of trade, product, or firm names is for descriptive purposes only and does not imply endorsement by the U.S. Government.

Although this report is in the public domain, permission must be secured from the individual copyright owners to reproduce any copyrighted materials contained within this report.

Suggested citation:

Frans, L.M., Bachmann, M.P., Sumioka, S.S., and Olsen, T.D., 2011, Conceptual model and numerical simulation of the groundwater-flow system of Bainbridge Island, Washington: U.S. Geological Survey Scientific Investigations Report 2011-5021, $96 \mathrm{p}$. 


\section{Contents}

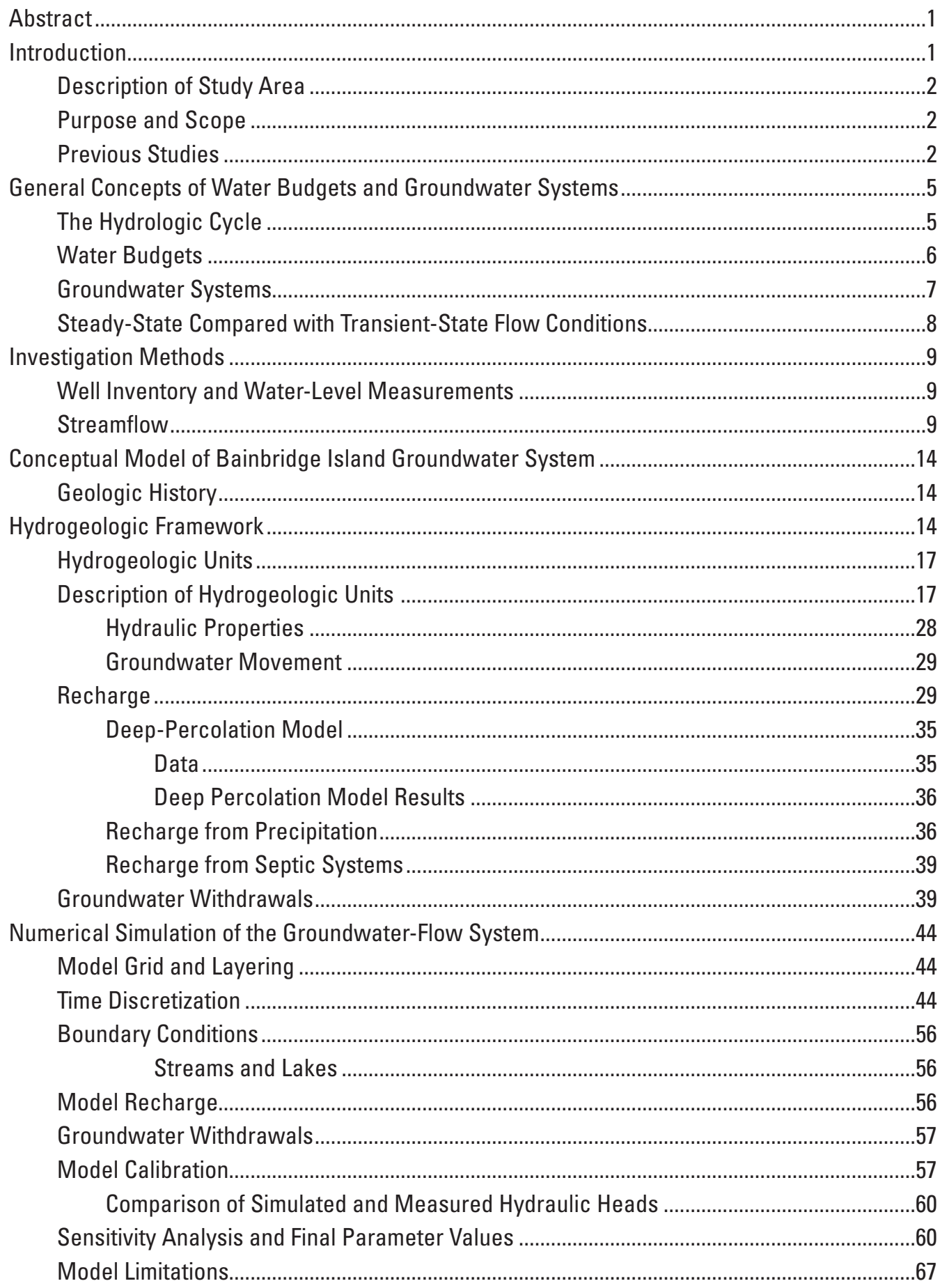




\section{Contents-Continued}

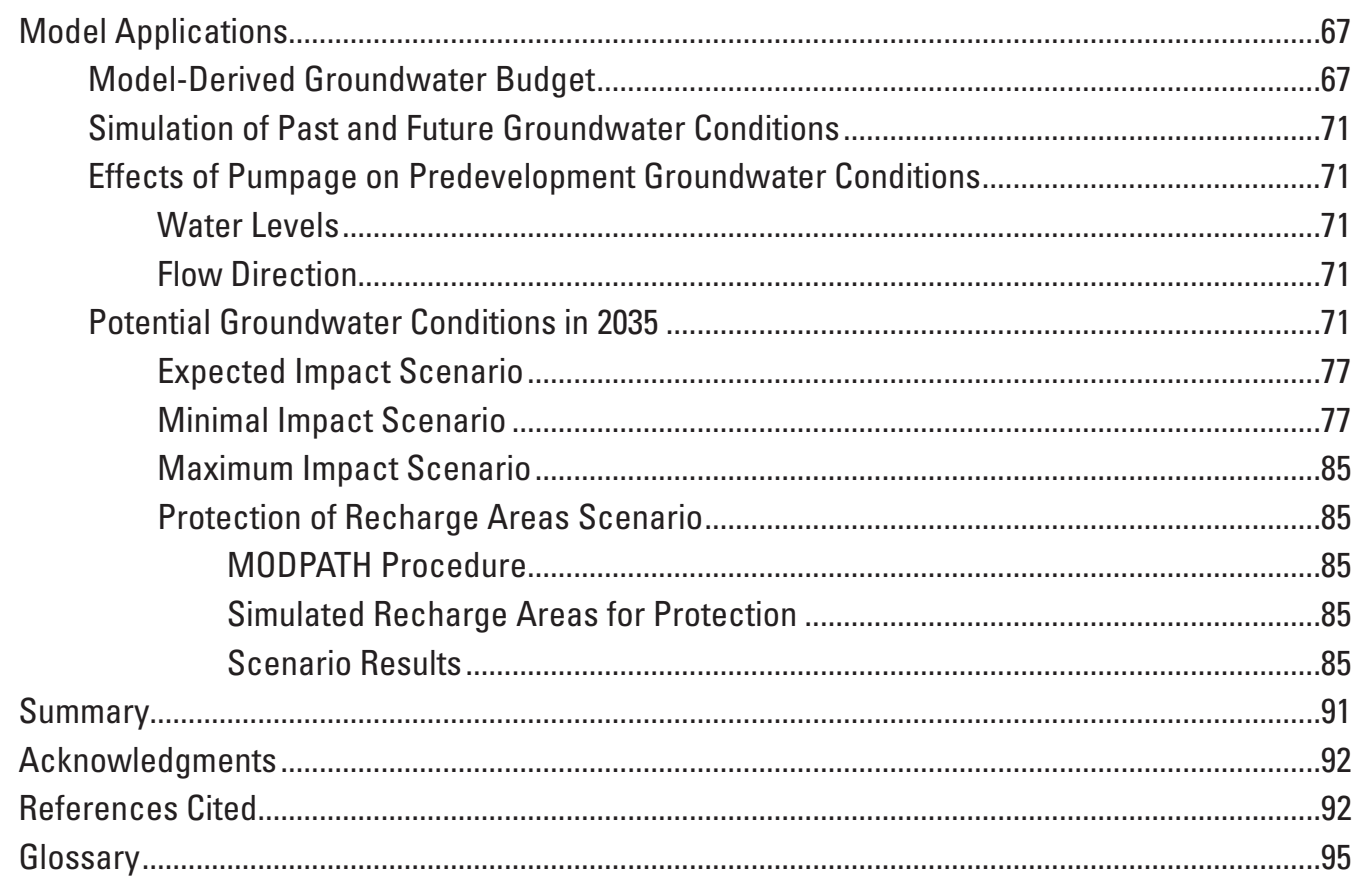

\section{Plate}

[In pocket]

Plate 1. Geologic map and cross sections showing hydrogeologic units on Bainbridge Island, Kitsap County, Washington

\section{Figures}

Figure 1. Map showing location of Bainbridge Island and vicinity, Kitsap County, Washington 3

Figure 2. Graphs showing average monthly precipitationand air temperature for Bremerton, Washington, 1971-2000

Figure 3. Graph showing population trends from 1980 to 2010 and projections from 2000 to

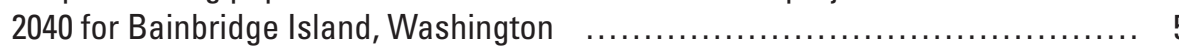

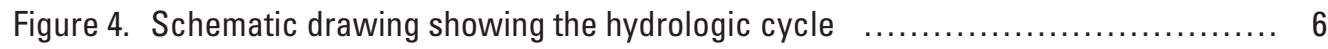

Figure 5. Schematic drawing showing features of unconfined (water table) and confined

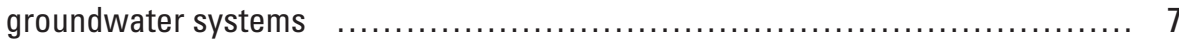

Figure 6. Map showing locations of wells used during the assessment of water resources

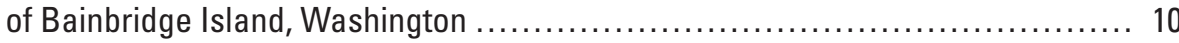

Figure 7. Map showing locations of sites where surface-water and meteorological data were collected during 2007 and 2008 on Bainbridge Island, Washington

Figure 8. Map showing surficial hydrogeologic units and cross sections, Bainbridge Island, Washington 


\section{Figures-Continued}

Figure 9. Map showing extent and thickness of Vashon till confining unit (Qvt), Bainbridge

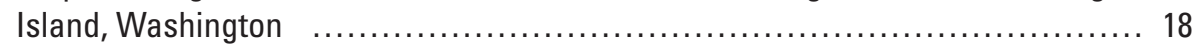

Figure 10. Map showing extent and thickness of Vashon advance aquifer (Ova), Bainbridge Island, Washington ............................................ 19

Figure 11. Map showing extent and thickness of the upper confining unit (OC1), Bainbridge Island, Washington ........................................ 21

Figure 12. Map showing extent and thickness of the permeable interbeds ( $\mathrm{CC} 1 \mathrm{pi}$ ),

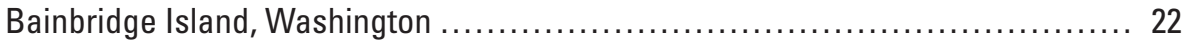

Figure 13. Map showing extent and thickness of the sea-level aquifer (OA1), Bainbridge Island, Washington

Figure 14. Map showing extent and thickness of the middle confining unit (OC2), Bainbridge Island, Washington .....

Figure 15. Map showing extent and thickness of the glaciomarine aquifer (QA2), Bainbridge Island, Washington

Figure 16. Map showing extent and thickness of the lower confining unit (QC3), Bainbridge Island, Washington ...................................... 26

Figure 17. Map showing extent and thickness of the deep aquifer (OA3), Bainbridge Island, Washington

Figure 18. Map showing water-level altitudes and direction of groundwater flow in the Vashon advance aquifer (Qva), Bainbridge Island, Washington, August 2007 ..... 30

Figure 19. Map showing water-level altitudes in the permeable interbed (OC1pi), Bainbridge Island, Washington, August 2007

Figure 20. Map showing water-level altitudes and direction of groundwater flow in the shallow aquifer (QA1), Bainbridge Island, Washington, August 2007

Figure 21. Map showing water-level altitudes in the glaciomarine aquifer (OA2), Bainbridge Island, Washington, August 2007

Figure 22. Map showing water-level altitudes in the deep aquifer (QA3), Bainbridge Island, Washington, August 2007

Figure 23. Graph showing streamflow at unnamed creek at Fletcher Bay Road, Bainbridge Island, Washington, 2006-08

Figure 24. Map showing average annual groundwater recharge from precipitation, Bainbridge Island, Washington

Figure 25. Map showing distribution of recharge due to septic-system return flows, Bainbridge Island, Washington, 2008

Figure 26. Map showing location of public-supply wells and their 2008 pumping rates, Bainbridge Island, Washington

Figure 27. Map showing location and number of domestic wells used to simulate groundwater pumping rates, Bainbridge Island, Washington

Figure 28. Map showing location and extent of the groundwater-flow model for Bainbridge Island and vicinity, Washington

Figure 29. Maps showing areal extent and location of drain and general-head cells for model layers, Bainbridge Island, Washington

Figure 30. Map showing horizontal distribution of pilot points used to calibrate the model domain, Bainbridge Island and vicinity, Washington

Figure 31. Graph showing simulated and observed hydraulic-head values in the groundwater-flow model of Bainbridge Island and vicinity, Washington 


\section{Figures-Continued}

Figure 32. Map showing location and simulated magnitude of hydraulic-head residuals in model layers, Bainbridge Island, Washington 61

Figure 33. Diagrams showing simulated water budgets for individual aquifers for 2008 and predevelopment conditions, Bainbridge Island, Washington

Figure 34. Maps showing simulated change in water levels between predevelopment and 2008 conditions in Vashon advance aquifer (Qva), sea-level aquifer (0A1), and deep aquifer (QA3), Bainbridge Island, Washington

Figure 35. Map showing simulated water levels and direction of groundwater flow under predevelopment conditions for the deep aquifer (QA3), Bainbridge Island, Washington

Figure 36. Graphs showing projected population growth and recharge amounts for the minimal, expected, and maximum impact scenarios for the Bainbridge Island, Washington

Figure 37. Maps showing simulated change in water level between 2008 and 2035 under expected impact scenarios for Vashon advance aquifer (Qva),sea-level aquifer (OA1), and deep aquifer (QA3), Bainbridge Island, Washington.

Figure 38. Map showing simulated water level and direction of groundwater flow in 2035 under the expected impact scenario for the deep aquifer (OA3), Bainbridge Island, Washington

Figure 39. Maps showing simulated change in water level between 2008 and 2035 under the minimal impact scenario for the Vashon advance aquifer (Qva), sea-level aquifer (QA1), and deep aquifer (QA3), Bainbridge Island, Washington

Figure 40. Maps showing simulated change in water level between 2008 and 2035 under the maximum impact scenario for the Vashon advance aquifer (Qva), sea-level aquifer (OA1), and deep aquifer (0A3), Bainbridge Island, Washington

Figure 41. Map showing simulated water level and direction of groundwater flow in 2035 under the maximum impact scenario for the deep aquifer (OA3), Bainbridge Island, Washington.

Figure 42. Map showing simulated recharge areas for water pumped at the City of Bainbridge Island Head of the Bay well field, Washington. 


\section{Tables}

Table 1. Surface water sites measured on Bainbridge Island, Washington 12

Table 2. Base flow-discharge measurements collected in 2007 and 2008, Bainbridge

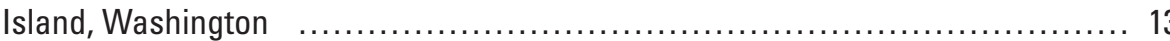

Table 3. Hydrogeologic unit labels and terminology used in groundwater studies of Bainbridge Island and surrounding areas, Kitsap County, Washington............ 16

Table 4. Summary of hydraulic-conductivity values estimated from specific-capacity data, by hydrogeologic unit, Bainbridge Island, Washington

Table 5. Monthly water-budget components for the unnamed study basin (site 12069895) on Bainbridge Island, Washington

Table 6. Calibration statistics for numerical flow model of Bainbridge Island and surrounding areas, Kitsap County, Washington.

Table 7. Summary of parameter sensitivities and final values for 1,110 pilot points, Bainbridge Island, Washington

Table 8. Water budget for predevelopment and 2008 conditions, Bainbridge Island, Washington

\section{Conversion Factors, Datums and Well-Numbering System}

Conversion Factors

\begin{tabular}{|c|c|c|}
\hline Multiply & By & To obtain \\
\hline \multicolumn{3}{|c|}{ Length } \\
\hline inch (in.) & 2.54 & centimeter $(\mathrm{cm})$ \\
\hline foot $(\mathrm{ft})$ & 0.3048 & meter (m) \\
\hline mile (mi) & 1.609 & kilometer $(\mathrm{km})$ \\
\hline \multicolumn{3}{|c|}{ Area } \\
\hline acre & 0.4047 & hectare (ha) \\
\hline square mile $\left(\mathrm{mi}^{2}\right)$ & 259.0 & hectare (ha) \\
\hline \multicolumn{3}{|c|}{ Volume } \\
\hline acre-foot (acre-ft) & 1,233 & cubic meter $\left(\mathrm{m}^{3}\right)$ \\
\hline cubic foot $\left(\mathrm{ft}^{3}\right)$ & 0.02832 & cubic meter $\left(\mathrm{m}^{3}\right)$ \\
\hline \multicolumn{3}{|c|}{ Flow rate } \\
\hline acre-foot per year (acre-ft/yr) & 1,233 & cubic meter per year (m³/yr) \\
\hline foot per day (ft/d) & 0.3048 & meter per day $(\mathrm{m} / \mathrm{d})$ \\
\hline cubic foot per second $\left(\mathrm{ft}^{3} / \mathrm{s}\right)$ & 0.02832 & cubic meter per second $\left(\mathrm{m}^{3} / \mathrm{s}\right)$ \\
\hline inch per year (in/yr) & 25.4 & millimeter per year (mm/yr) \\
\hline
\end{tabular}

Temperature in degrees Fahrenheit $\left({ }^{\circ} \mathrm{F}\right)$ may be converted to degrees Celsius $\left({ }^{\circ} \mathrm{C}\right)$ as follows:

$$
{ }^{\circ} \mathrm{C}=\left({ }^{\circ} \mathrm{F}-32\right) / 1.8 \text {. }
$$

Datums

Vertical coordinate information is referenced to the North American Vertical Datum of 1988 (NAVD 88).

Horizontal coordinate information is referenced to the North American Datum of 1983 (NAD 83).

Altitude, as used in this report, refers to distance above the vertical datum. 


\section{Conversion Factors, Datums and Well-Numbering System- Continued}

\section{Well-Numbering System}

In the State of Washington, wells and springs are assigned numbers that identify their location within a township, range, section, and 40 -acre tract. For example, local well number $25 \mathrm{~N} / 02 \mathrm{E}-15001$ indicates that the well is in township 25 north and range 2 east, north and east of the Willamette Base Line and Meridian, respectively. The numbers immediately following the hyphen indicate the section (15) within the township; the letter following the section gives the 40 -acre tract of the section. The two-digit sequence number (01) following the letter indicates that the well was the first one inventoried by U.S. Geological Survey personnel in that 40 -acre tract. An "S," " $D$," or "P" following the sequence number indicates that the site is a spring, deepened well, or piezometer in a well, respectively. In the figures of this report, wells and springs are identified individually by only the section and 40 -acre tract, such as 15001; township and range are shown on the map borders.

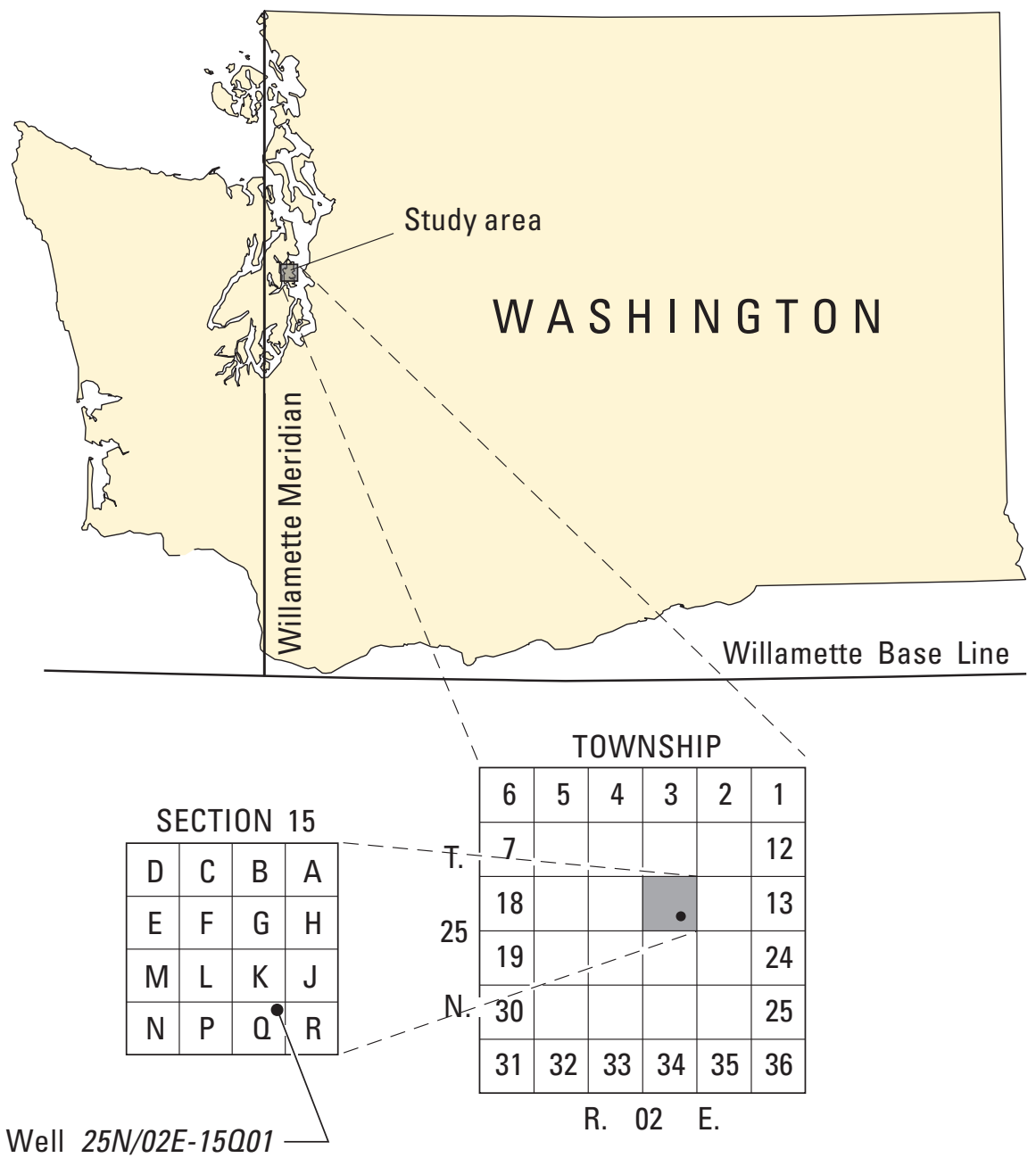




\title{
Conceptual Model and Numerical Simulation of the Groundwater-Flow System of Bainbridge Island, Washington
}

\author{
By Lonna M. Frans, Matthew P. Bachmann, Steve S. Sumioka, and Theresa D. Olsen
}

\section{Abstract}

Groundwater is the sole source of drinking water for the population of Bainbridge Island. Increased use of groundwater supplies on Bainbridge Island as the population has grown over time has created concern about the quantity of water available and whether saltwater intrusion will occur as groundwater usage increases. A groundwater-flow model was developed to aid in the understanding of the groundwater system and the effects of groundwater development alternatives on the water resources of Bainbridge Island.

Bainbridge Island is underlain by unconsolidated deposits of glacial and nonglacial origin. The surficial geologic units and the deposits at depth were differentiated into aquifers and confining units on the basis of areal extent and general water-bearing characteristics. Eleven principal hydrogeologic units are recognized in the study area and form the basis of the groundwater-flow model.

A transient variable-density groundwater-flow model of Bainbridge Island and the surrounding area was developed to simulate current (2008) groundwater conditions. The model was calibrated to water levels measured during 2007 and 2008 using parameter estimation (PEST) to minimize the weighted differences or residuals between simulated and measured hydraulic head.

The calibrated model was used to make some general observations of the groundwater system in 2008. Total flow through the groundwater system was about 31,000 acre-ft/yr. The recharge to the groundwater system was from precipitation and septic-system returns. Groundwater flow to Bainbridge Island accounted for about 1,000 acre-ft/yr or slightly more than 5 percent of the recharge amounts. Groundwater discharge was predominately to streams, lakes, springs, and seepage faces (16,000 acre-ft/yr) and directly to marine waters $(10,000$ acre-ft/yr). Total groundwater withdrawals in 2008 were slightly more than 6 percent $(2,000 \mathrm{acre}-\mathrm{ft} / \mathrm{yr})$ of the total flow.
The calibrated model was used to simulate predevelopment conditions, during which no groundwater pumping or secondary recharge occurred and currently developed land was covered by conifer forests. Simulated water levels in the uppermost aquifer generally were slightly higher at the end of 2008 than under predevelopment conditions, likely due to increased recharge from septic returns and reduced evapotranspiration losses due to conversion of land cover from forests to current conditions. Simulated changes in water levels for the extensively used sea-level aquifer were variable, although areas with declines between zero and 10 feet were common and generally can be traced to withdrawals from public-supply drinking wells. Simulated water-level declines in the deep (Fletcher Bay) aquifer between predevelopment and 2008 conditions ranged from about 10 feet in the northeast to about 25 feet on the western edge of the Island. These declines are related to groundwater withdrawals for public-supply purposes.

The calibrated model also was used to simulate the possible effects of increased groundwater pumping and changes to recharge due to changes in land use and climactic conditions between 2008 and 2035 under minimal, expected, and maximum impact conditions. Drawdowns generally were small for most of the Island (less than $10 \mathrm{ft}$ ) for the minimal and expected impact scenarios, and were larger for the maximum impact scenario. No saltwater intrusion was evident in any scenario by the year 2035. The direction of flow in the deep Fletcher Bay aquifer was simulated to reverse direction from its predevelopment west to east direction to an east to west direction under the maximum impact scenario.

\section{Introduction}

Groundwater is the sole source of drinking water for the population of Bainbridge Island. Consequently, as the population grows, so does the demand for groundwater. However, the quantity of usable groundwater likely is limited, mostly because of the island environment and the potential for seawater intrusion as groundwater usage increases. 
Under the Water Resources Element, Goals and

Policies section of the City of Bainbridge Island (2004)

Comprehensive Plan, Goal 1 states:

"Protection of water resources is of primary importance to the Island. Therefore, the goal is to manage the water resources of Bainbridge Island for present and projected land uses, recognizing Island water resources are the sole water supply and that:

- Degradation of groundwater quality and quantity is not allowed.

- Water supplies and systems are efficiently utilized.

- The long-term sustainability of the Island's water resources is maintained.

- The water needs of new development approved under the Comprehensive Plan are adequately met.

- Adequate data of the water resource is available."

An island-wide, groundwater model can be used as a tool in making water-resource management decisions in order to achieve the goal stated above.

\section{Description of Study Area}

Bainbridge Island (referred to as the Island in this report) lies in the Puget Sound lowland of west-central Washington (fig. 1) and is bounded by Puget Sound on the east, Rich Passage on the south, Port Orchard on the west, and Port Madison on the north. The Island is in eastern Kitsap County, on the east side of the Kitsap Peninsula.

The Island has an area of approximately $27.5 \mathrm{mi}^{2}$ and is about $3.5 \mathrm{mi}$ wide and $10.5 \mathrm{mi}$ long. The land surface is gently rolling, and altitudes range from sea level to about $400 \mathrm{ft}$ above sea level. Gazzam Lake is the only lake on the Island, and surface drainage generally is by small, spring-fed streams that discharge directly to Puget Sound. Many smaller streams become dry in the summer months.

The study area has a temperate marine climate that is typical of the Puget Sound lowland, with warm, dry summers and cool, wet winters. The long-term average annual precipitation at Bremerton, Wash. (fig. 1), just southwest of the study area, is $53.96 \mathrm{in} / \mathrm{yr}$ for 1971-2000; November and December are the wettest months and July and August the driest (fig. 2A). Precipitation at Bremerton during the 2 years of data collection for this study was 51.74 in. from April 2007 to March 2008 and 34.81 in. from April 2008 to March 2009. These amounts are 96 percent and 65 percent of the long-term average, respectively. Temperatures are mild throughout the year. The average monthly maximum is $75.8^{\circ} \mathrm{F}$ in August and the average monthly minimum is $34.7^{\circ} \mathrm{F}$ in January (fig. $2 B$ ).
According to the Puget Sound Regional Council, 22,958 people were living on Bainbridge Island in 2010, which represents an increase of more than 13 percent since 2000 (fig. 3; Puget Sound Regional Council, 2006). Population is expected to increase by more than 31 percent between 2010 and 2030. Currently, the population is spread fairly evenly over most of the Island with the highest density in the Winslow area (fig. 1).

\section{Purpose and Scope}

The purpose of this report is to describe the hydrogeologic framework and groundwater flow in the study area and to document the development of a transient numerical groundwater-flow model of the study area. The conceptual model sections in this report describe the geologic history of the study area, the surficial geology of Bainbridge Island, the physical characteristics of individual hydrogeologic units, and groundwater levels and flow directions. The numerical model section of the report describes the construction and calibration of the numerical model, limitations of the model, and specific scenarios that were simulated using the model.

\section{Previous Studies}

The geology and groundwater resources of Bainbridge Island have been described in previous reports of broader geographic areas, such as Kitsap County or the entire Kitsap Peninsula. The first of these reports (Sceva, 1957) described the groundwater resources of Kitsap County, and a subsequent report by Garling and others (1965) described the groundwater and surface-water resources of the Kitsap Peninsula. Deeter (1979) described the geology and stratigraphy of Kitsap County, and Hansen and Bolke (1980) described groundwater availability on the Kitsap Peninsula. A comprehensive update of the water resources of Kitsap County was prepared by the Kitsap County Ground Water Advisory Committee and others (1991) as part of the Kitsap County groundwater management plan and includes hydrogeologic cross sections and determination of principal aquifers. None of these reports, however, specifically addressed the groundwater hydrology of Bainbridge Island.

A report by Dion and others (1988) was the first to specifically describe the water resources of Bainbridge Island. The report described the hydrogeologic framework and water quality of the shallow groundwater system. Most recently, a comprehensive hydrogeologic assessment known as a Level II Basin Assessment was completed for the Island (Kato and Warren, Inc., and Robinson and Noble, Inc., 2000). The report describes the surface-water and groundwater resources of the Island including cross-sections and maps showing the extent of the various hydrogeologic units present on the Island. 


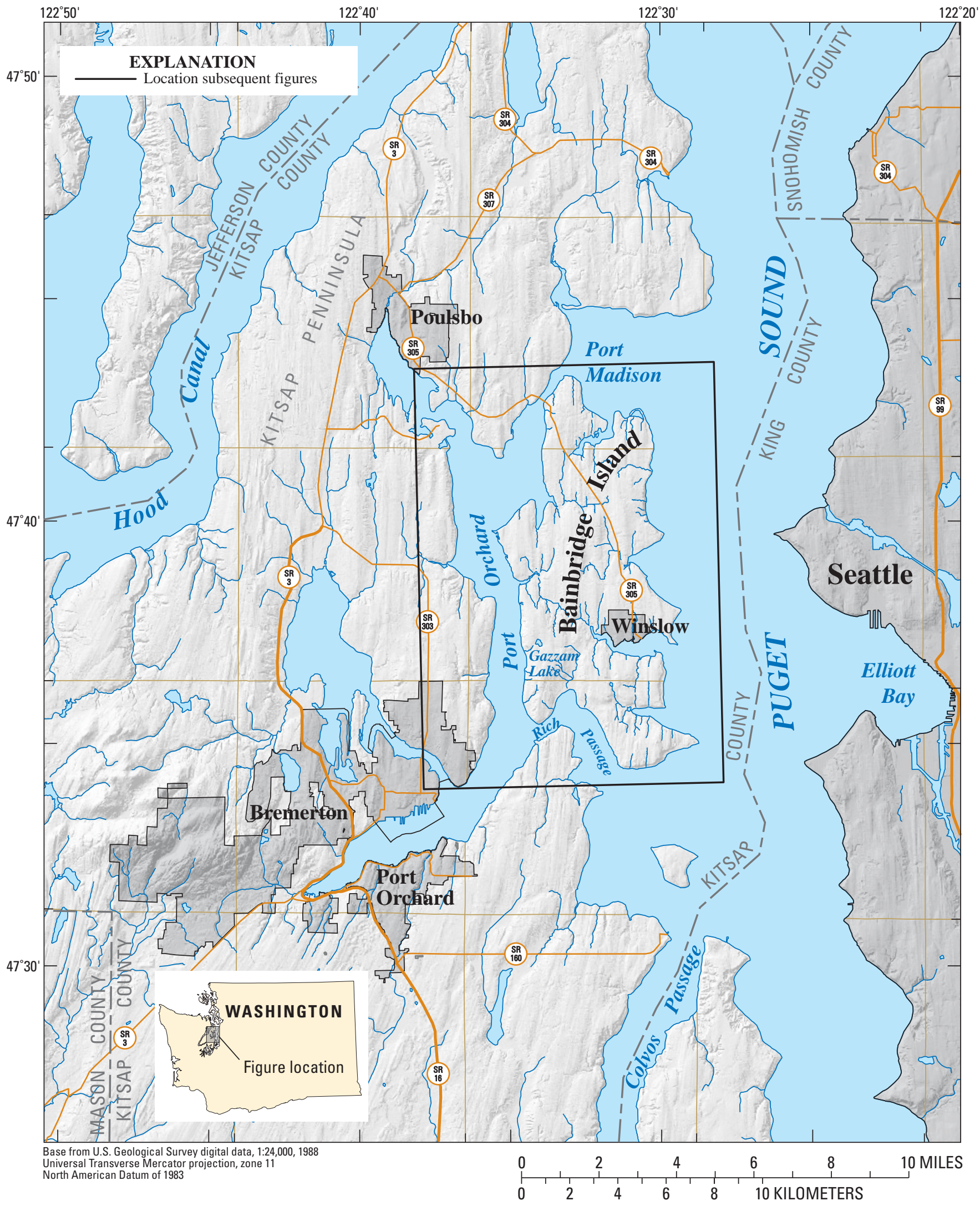

Figure 1. Bainbridge Island and vicinity, Kitsap County, Washington. 

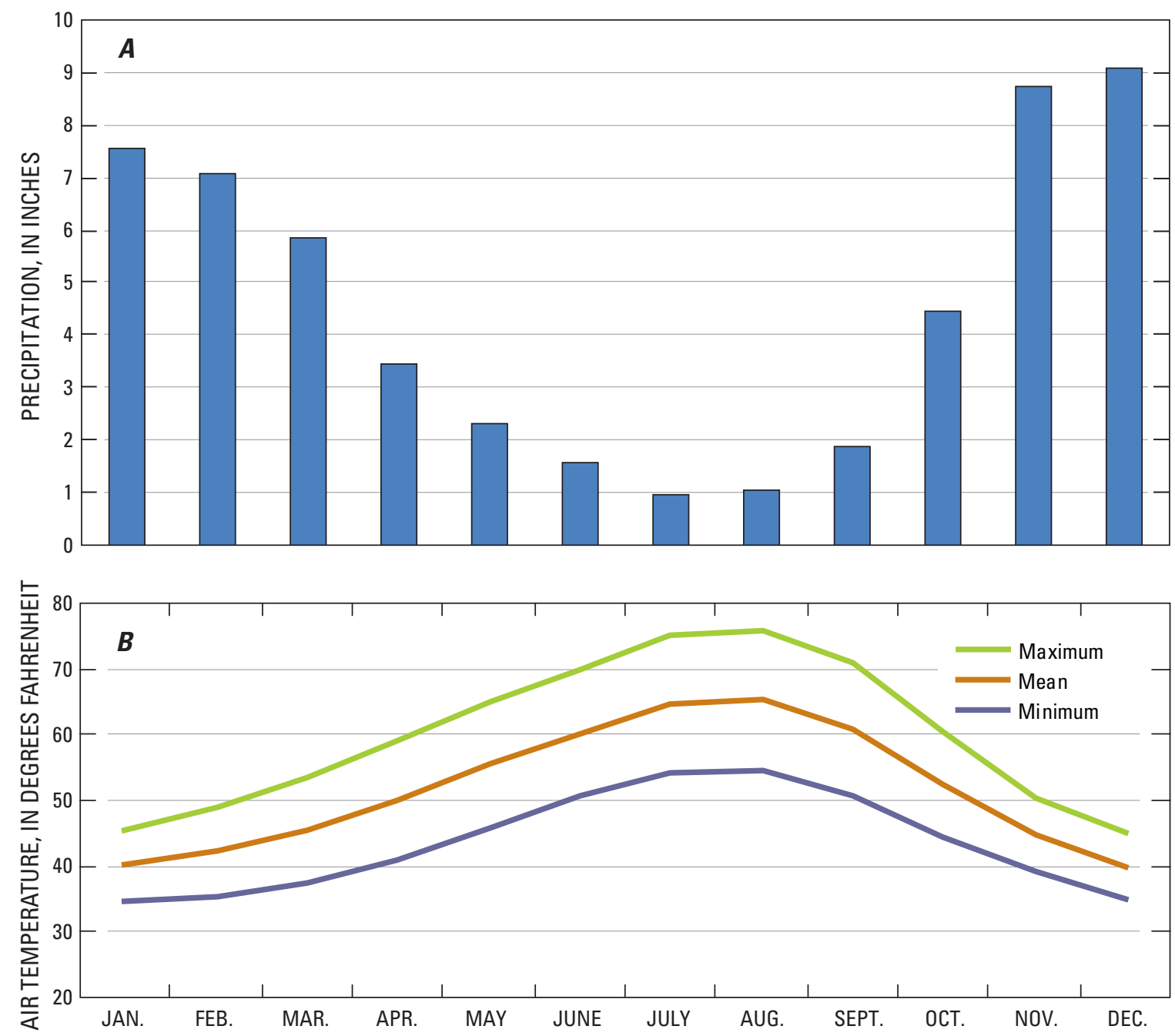

Figure 2. Average monthly precipitation $(A)$ and air temperature $(B)$ for Bremerton, Washington, 1971-2000. 


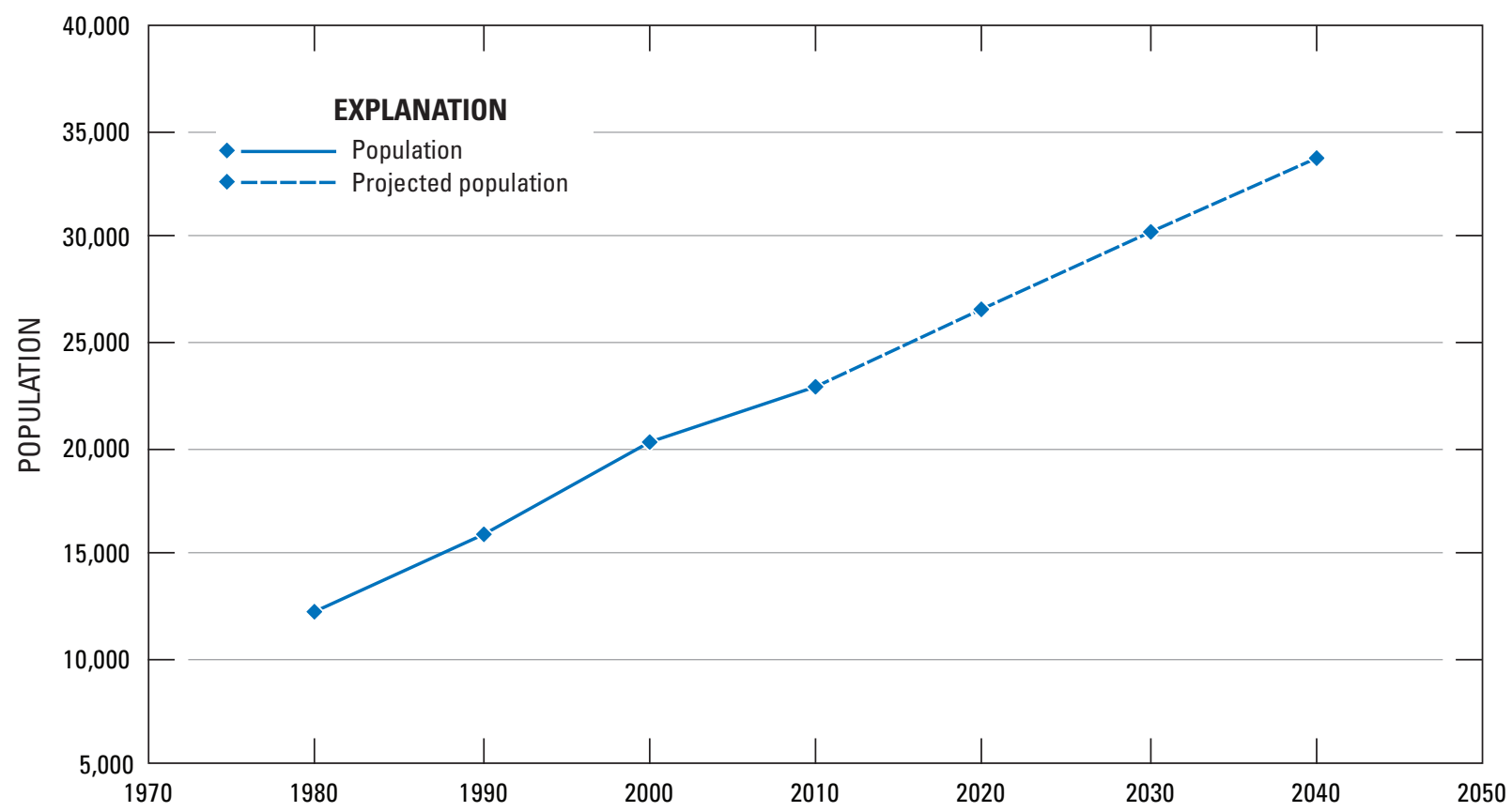

Figure 3. Population trends from 1980 to 2010 and projections from 2000 to 2040 for Bainbridge Island, Washington.

\section{General Concepts of Water Budgets and Groundwater Systems}

The following section provides general concepts and definitions to help the reader understand the modeling results presented in this report. The Groundwater Systems sub-section is modified from Thomas and others (1997).

\section{The Hydrologic Cycle}

The hydrologic cycle describes the circulation and conservation of the Earth's water as it moves from location to location (fig. 4). As the water moves through the cycle, it is typically stored temporarily in oceans, lakes, rivers, soil, and atmosphere, or in groundwater. Although the cycle does not have an end or a beginning, this simplified description starts with the movement of water from the Earth's surface to the atmosphere.

The hydrologic cycle begins with the evaporation of water from the surface of the ocean or land or through transpiration by plants. The combination of these processes is called evapotranspiration. As the moist air is lifted, it cools and the vapor condenses to form clouds. The moisture returns from the clouds to the surface as precipitation. Once the water reaches the ground, one of several processes may occur: (1) some of the water may evaporate or be transpired by plants back into the atmosphere, (2) the water may runoff directly to streams and lakes, or (3) the water may infiltrate the surface and recharge the groundwater system. Groundwater either seeps its way into the oceans, rivers, and streams, or is released back into the atmosphere through transpiration by plants. The water that empties into lakes, rivers and streams is carried back to the oceans, where the cycle begins again. 


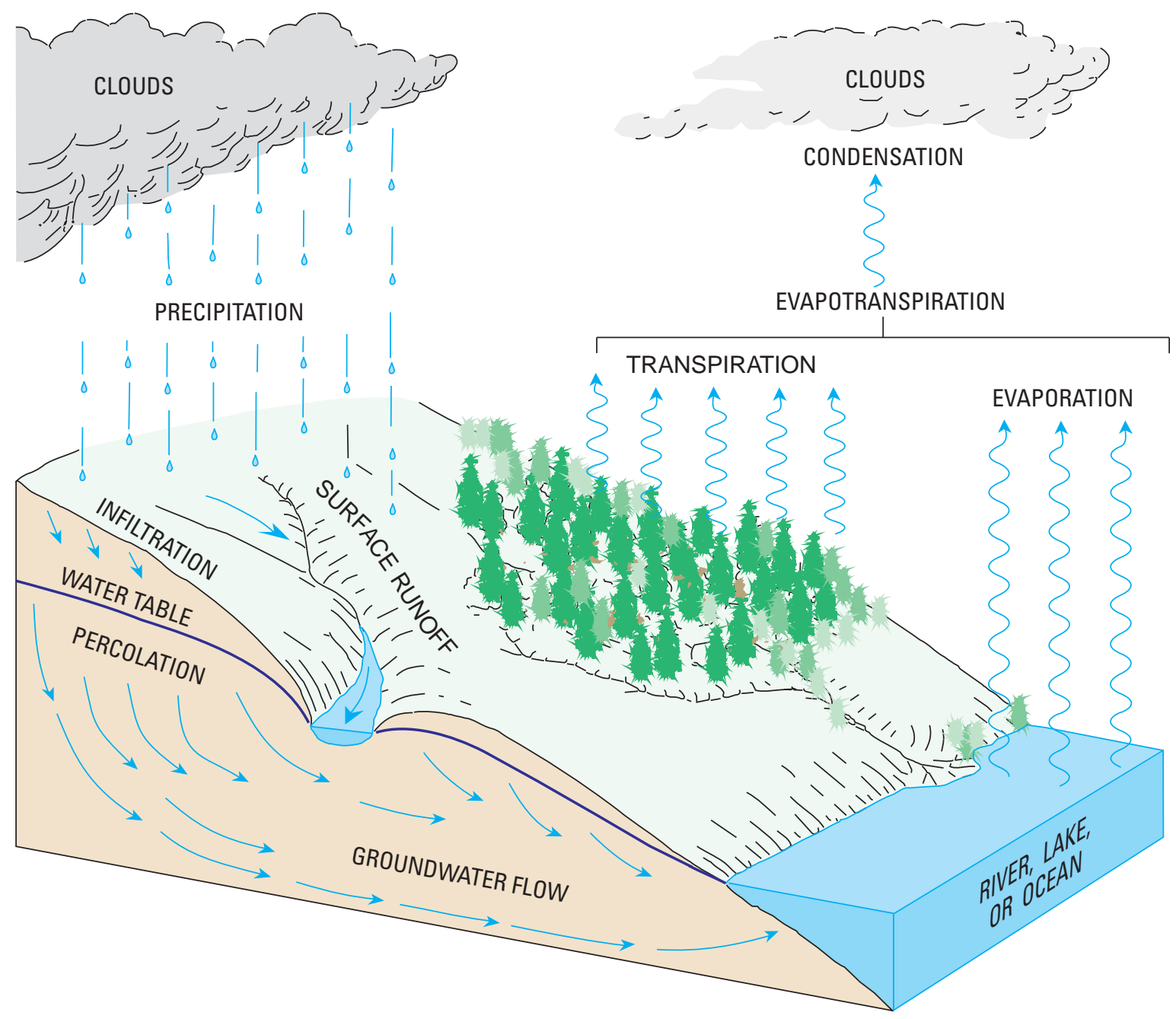

Figure 4. The hydrologic cycle.

\section{Water Budgets}

The hydrologic cycle for a given area also can be represented mathematically in the form of a water-balance equation. This equation is useful in determining the size of the various components of the system and evaluating how changes in one component will affect the others. The waterbalance equation for the amount of water entering and leaving Bainbridge Island can be expressed as follows:

$$
P+G W_{1}=E T+S W_{o}+G W_{o}+G W_{w},
$$

where

$$
P \text { is precipitation, }
$$

$G W_{1}$ is groundwater inflow,

$E T$ is evapotranspiration,

$S W_{o}$ is surface-water outflow,

$G W_{o}$ is groundwater outflow, and

$G W_{w}$ is groundwater withdrawals.
Precipitation also can be expressed as follows:

$$
P=S R+E T+G W R,
$$

where

$S R$ is surface runoff (including surface runoff and shallow-subsurface flow); and,

GWR is groundwater recharge.

These equations assume that there is no change in groundwater storage and that groundwater recharge equals groundwater discharge. Most steady-state groundwater systems roughly meet these conditions over the course of a year. 


\section{Groundwater Systems}

A groundwater system is a body of porous material that is saturated with water. The body of porous material can be fractured rock or the weathered products of rock such as gravel, sand, or silt. A general definition of a groundwater system includes a description of the: (1) boundaries of the system geometry, (2) inflow and outflow of water through the boundaries (recharge and discharge), (3) directions and rates of groundwater flow, and (4) hydraulic properties of the porous material.

A groundwater system consists of a single aquifer or multiple aquifers and confining units. An aquifer is a body of porous material that will yield water in a usable quantity to a well or spring. A confining unit is a body of porous material having relatively low hydraulic conductivity that restricts the movement of groundwater either into or out of adjacent aquifers.

The boundaries of a groundwater system define a threedimensional surface that encloses the aquifers and confining units. Examples of boundaries are (1) the water table, which is a surface marking the upper limit of the saturated groundwater system, (2) relatively impermeable bedrock, which is a surface marking the bottom and possibly lateral limits of the system, (3) the surface of contact between an aquifer and a river or lake, or (4) the surface of contact between an aquifer and a saline water body such as the ocean.

Groundwater is under either unconfined or confined conditions (fig. 5). Unconfined groundwater only partly fills an aquifer, and the top surface of the groundwater body is the water table. A water level measured in a well screened at the water table in an unconfined aquifer will stand at the same level as the water table. Confined groundwater is under pressure, and its upper limit is the bottom surface of an overlying confining unit. A water level measured in a well that is screened in a confined aquifer will stand above the top of the confined aquifer. "Artesian" is a commonly used term and with respect to aquifers is synonymous with confined. An artesian well is a well deriving its water from an artesian or confined aquifer. If the water level in an artesian well stands above land surface, the well is a flowing artesian well. Water will flow naturally out of such wells because the total hydraulic head of the confined groundwater is greater than the altitude of the top of the open well.

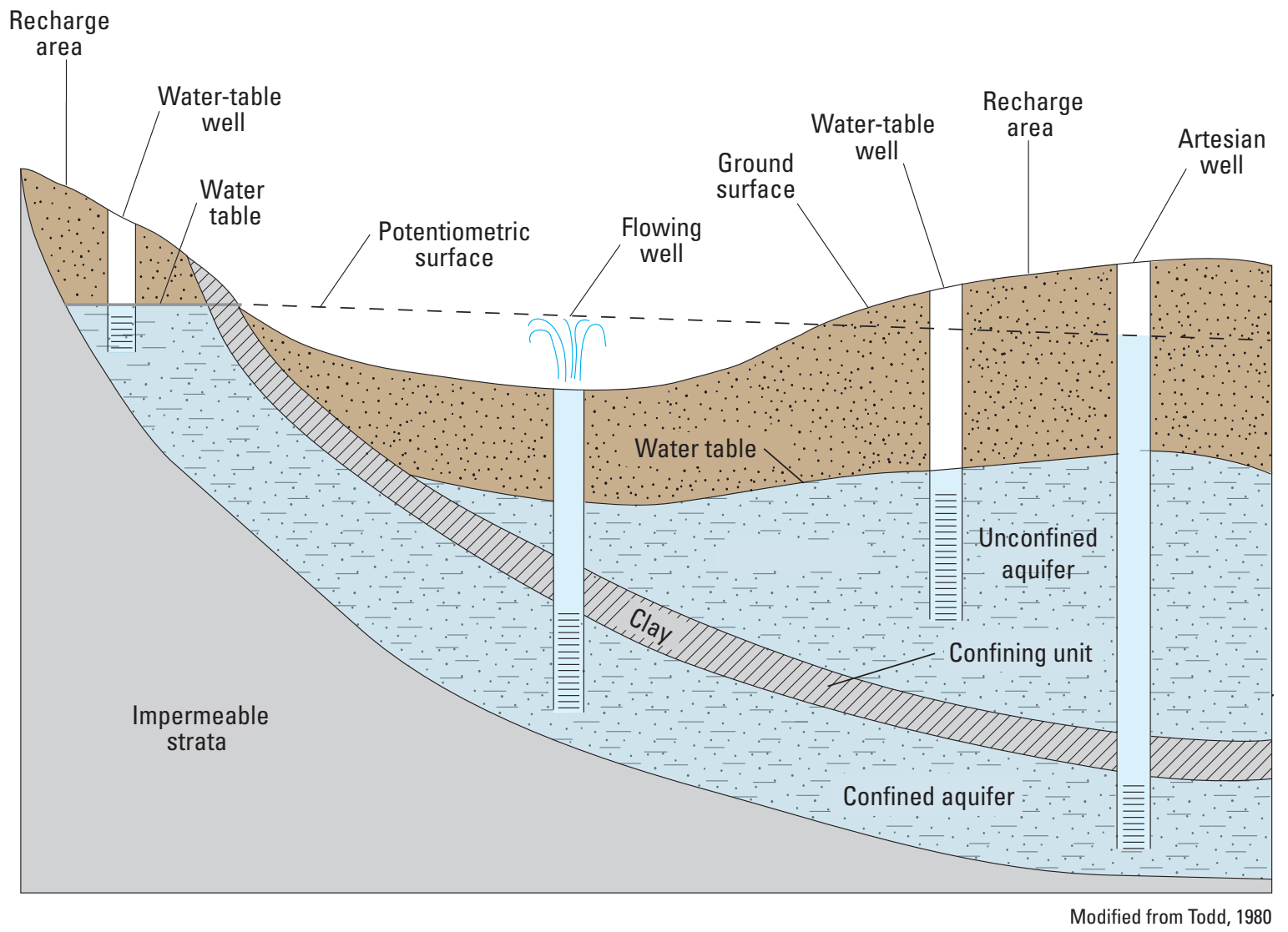

Figure 5. Features of unconfined (water table) and confined groundwater systems. 
A groundwater boundary can have three flow conditions; no flow, inflow (recharge), or outflow (discharge). The flow condition depends on the relation between the heads on either side of the boundary and the permeability of the material on either side of the boundary.

The direction of groundwater flow into, out of, or within a groundwater system is determined by comparing hydraulic heads. Groundwater moves from higher to lower head. Heads are determined by measuring the position of the water level in a well and relating the measurement to a reference elevation or datum. A datum that is common to all wells in an area is used for comparisons. NAVD 88 is used for the datum in this report, and measured water levels are reported as an altitude, in feet above sea level. A potentiometric surface is an areal representation of the hydraulic head in an aquifer. Thus, comparing two heads can be used to determine direction of flow between two points with flow moving from areas of higher head to areas of lower head, and the potentiometric surface indicates direction of flow for the entire area. The term "water table" is defined as the potentiometric surface at which the water pressure is the same as atmospheric pressure.

The general characteristics of a particular type of boundary, one between a freshwater aquifer and a saline water body, merits discussion because the groundwater system on the Island has this type of boundary along Puget Sound. The relation between fresh groundwater and saline groundwater can be described by some physical principles. Freshwater will float on saltwater because the relative density of freshwater (1.00) is slightly less than that of seawater (1.025). The Ghyben- Herzberg principle states that for a freshwater lens sitting on an intruded body of saltwater, for every $1 \mathrm{ft}$ of altitude of the water table above sea level, fresh groundwater will extend $40 \mathrm{ft}$ below sea level. For example, if the water table at a given site is $5 \mathrm{ft}$ above sea level, the freshwatersaltwater boundary theoretically is $200 \mathrm{ft}$ below sea level. The boundary is not sharp, but rather is a diffusion zone in which the salt concentration of the freshwater gradually increases with distance from the freshwater body until it reaches the concentration of the saltwater body. In addition to the relative densities of the freshwater and seawater, the position of the boundary also is affected by tides, the seasonal position of the water table, the hydraulic characteristics of the aquifer, and recharge-discharge relations within the aquifer.

In natural conditions of equilibrium, the altitude of the potentiometric surface of an aquifer is higher than sea level and decreases toward the shoreline, and the freshwatersaltwater boundary (zone of diffusion) is maintained in a relatively constant position. Stresses to aquifers, such as a large amount of pumping can cause a decline in groundwater levels and seawater intrusion, which is the landward or upward movement of the boundary between freshwater and saltwater.

The hydraulic properties of an aquifer or confining unit include the hydraulic conductivity, transmissivity, and storage capacity. Hydraulic conductivity is a measure of the relative ease with which a body of porous material can transmit water under a potential gradient. The rate of movement of groundwater, therefore, is proportional to the magnitude of the hydraulic conductivity. The shape, size, and interconnections of the pores of the material are the major factors controlling the magnitude of hydraulic conductivity. Transmissivity is a measure of the productivity of an aquifer in which flow is approximately horizontal and is equal to the hydraulic conductivity multiplied by the saturated thickness of the aquifer.

The storage capacity of an aquifer influences the amount of water that is available for withdrawal. In an unconfined aquifer, specific yield is a measure of the storage capacity. Specific yield of rock or soil material is the ratio of (1) the volume of water that the rock or soil, after being saturated, will yield by gravity to (2) the total volume of the rock or soil. Specific yield is dimensionless and values typically range from 0.1 to 0.3 (Heath, 1993). In a confined aquifer, the storage coefficient is the measure of storage capacity and is the volume of water that an aquifer releases from or takes into storage per unit surface area of the aquifer per unit change in head. It is equal to the specific storage multiplied by the saturated thickness of the aquifer, where the specific storage is the volume of water that a unit volume of aquifer releases from or takes into storage per unit change in head. The storage coefficient is dimensionless and typical values range from 0.00001 to 0.001 (Heath, 1993).

\section{Steady-State Compared with Transient-State Flow Conditions}

A groundwater system may be in a steady-state or transient-state condition in relation to time. In a steady-state system the quantity of inflow is balanced by the quantity of outflow and storage change within the system is zero. Under such conditions, water levels may fluctuate seasonally in response to variations in precipitation; however, the long-term average water level at a given location remains constant. In contrast, a system in a transient-state condition will have longterm changes in water levels owing to changes in inflows and (or) outflows and (or) storage. 


\section{Investigation Methods}

Lithologic logs, groundwater measurements in wells, streamflow measurements, and precipitation and other meteorological data were the primary sources of information used to define the current hydrogeologic framework and groundwater and surface-water systems. The hydrogeologic framework was constructed by correlating the lithology between individual wells described in drillers' well logs. Groundwater flow and hydraulic properties of the aquifers were estimated by measuring water levels and using wellpumpage data, respectively. Groundwater recharge was estimated using the Deep Percolation Model (Bauer and Mastin, 1997) which utilizes precipitation, evapotranspiration, and streamflow data.

\section{Well Inventory and Water-Level Measurements}

The groundwater-flow system was characterized based on the analysis of spatially distributed information about groundwater levels, and the physical and hydraulic properties of the geologic units documented during well construction. Spatial information was obtained through the measurement of water levels in wells, and the compilation and analysis of hydrogeologic descriptions and well tests from well drillers' logs. Well records that document the drilling (drillers' log description of borehole lithology), construction, and hydraulic testing of wells were compiled from U.S. Geological Survey (USGS) and Washington State Department of Ecology databases to identify candidate wells for this study. Candidate wells were selected for field inventory based on the location and depth of the well, and the availability of a complete well record with drillers' log. Well records with insufficient well location and construction information or incomplete or poorly constrained drillers' logs were not used in this study. The goal of the inventory was to obtain an even distribution of wells throughout the study area and within each aquifer. However, this was not possible for the entire study area because of a lack of wells in less populated areas.

Data from more than 400 wells were used in this study (fig. 6). During a field inventory in the spring and summer of 2007, permission was obtained from selected well owners and synoptic water-level measurements were made, where possible, in more than 100 wells. Data from the remaining wells were collected during previous studies. Synoptic water levels were measured at 86 wells during a 1-week period in August 2007, and water levels were measured in 73 of those wells approximately monthly over a 2-year period (igg. 6).
Latitude and longitude locations were determined for each well during the field inventory using a Global Positioning System (GPS) receiver with a horizontal accuracy of onetenth of a second (about $10 \mathrm{ft}$ ). Light Detection and Ranging (LiDAR) data were obtained through the Puget Sound LiDAR Consortium (2000) and were used to determine the altitude of land surface at each well and to subsequently compute waterlevel altitudes. Vertical accuracy of the LiDAR data typically was $\pm 1 \mathrm{ft}$.

Water level, reported as depth to water below land surface, was measured using a calibrated electric tape or graduated steel tape, both with a stated accuracy of $0.01 \mathrm{ft}$. There also was the potential for error in depth-towater measurements associated with borehole deviation in subvertical wells. All water-level measurements were made by USGS or City of Bainbridge Island personnel in accordance with standard techniques of the USGS (Drost, 2005). Waterlevel altitudes were determined by subtracting the measured depth-to-water below land surface from the LiDAR derived land-surface altitude at the well.

\section{Streamflow}

Synoptic stream base flow measurements were collected at 20 locations in May, July, and September of 2007 and 2008 (fig. 7, tables 1 and 2). These data were used to quantify the amount of surface water leaving the study area and to delineate gaining and losing stream reaches during low-flow conditions. Streamflow measurements were made by USGS personnel, assisted by City of Bainbridge Island personnel, using Price (pygmy or AA) or FlowTracker Handheld ADV® current velocity meters or flumes according to standard techniques of the USGS (Rantz, 1982). Flow in very small streams was measured using volumetric techniques. The USGS assigns accuracy ratings of good, fair, or poor to streamflow measurements based on the equipment, character of the measurement section, number of observations, stability of stage, wind conditions, and the accuracy of depth and velocity measurements (Rantz, 1982, p. 179). "Good" indicates that the measurements are judged to be within 5 percent of true values, "fair" indicates that the measurements are judged to be within 8 percent of true values, and "poor" indicates that the measurements are judged not to be within 8 percent of true values. 


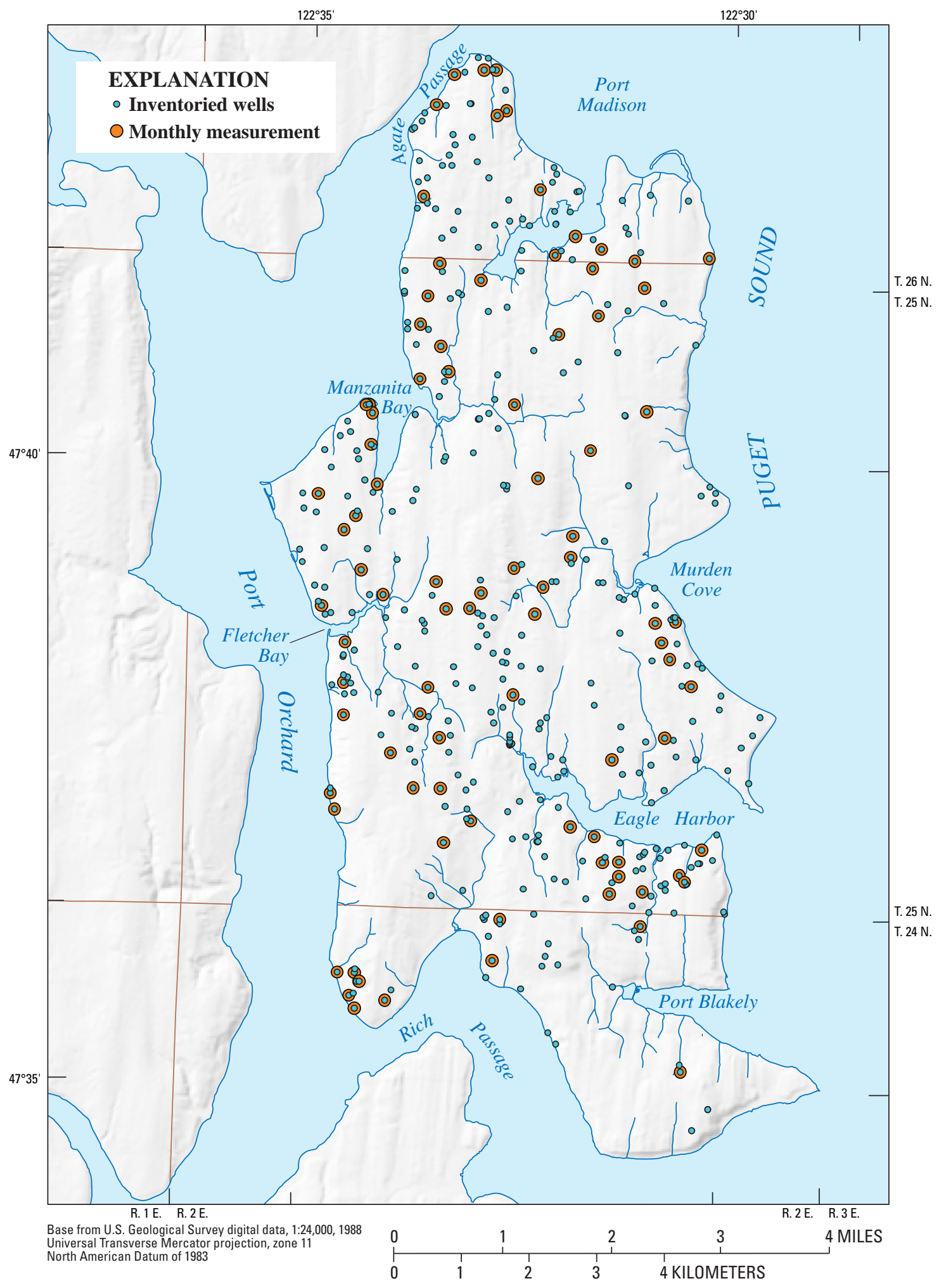

Figure 6. Locations of wells used during the assessment of water resources of Bainbridge Island, Washington. 


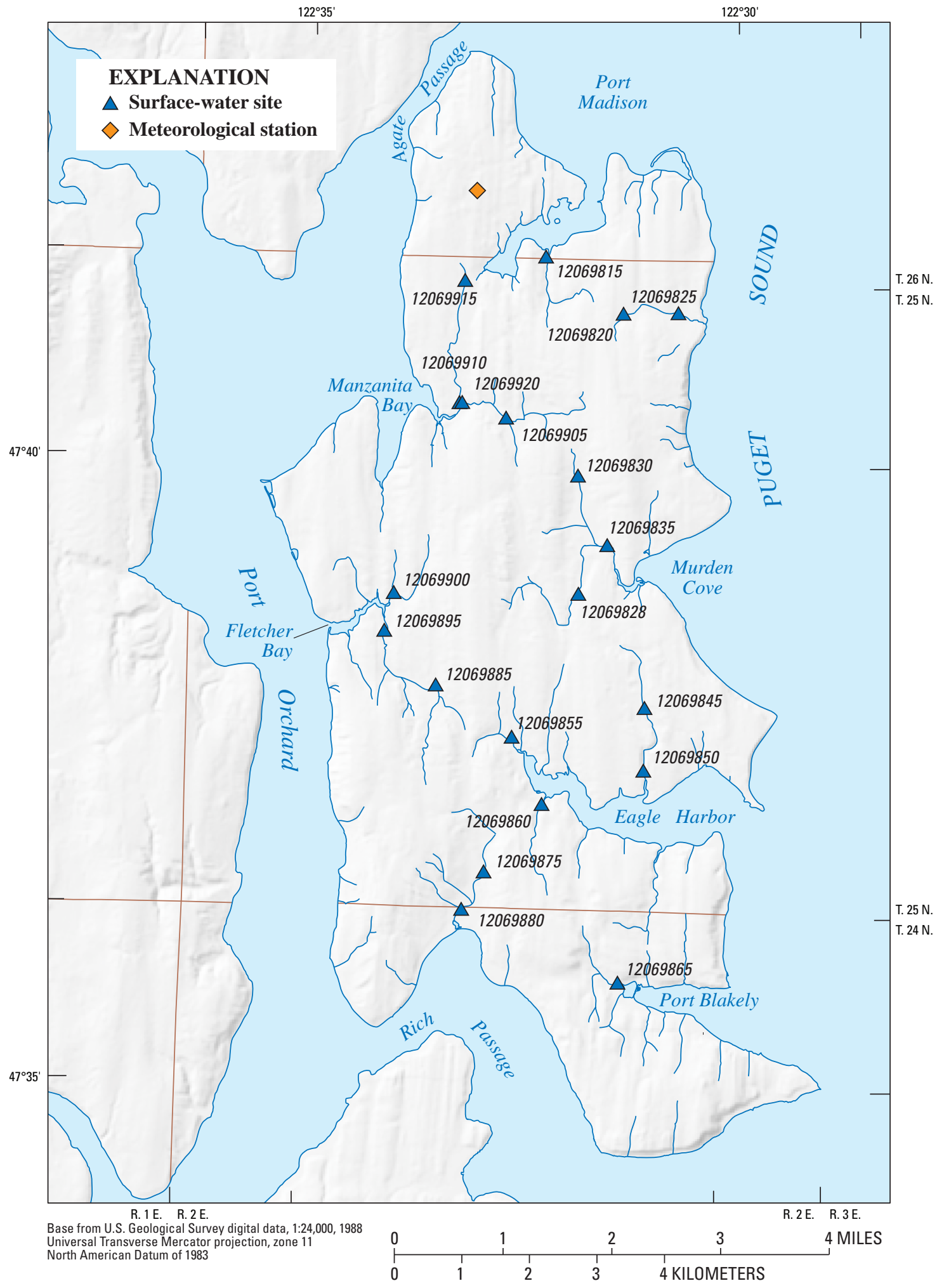

Figure 7. Locations of sites where surface-water and meteorological data were collected during 2007 and 2008 on Bainbridge Island, Washington. 
Table 1. Surface water sites measured on Bainbridge Island, Washington.

[Surface water sites measured by the U.S. Geological Survey on Bainbridge Island, Washington]

\begin{tabular}{clcc}
\hline $\begin{array}{c}\text { Site } \\
\text { No. }\end{array}$ & Site name & $\begin{array}{c}\text { Decimal } \\
\text { latitude }\end{array}$ & $\begin{array}{c}\text { Decimal } \\
\text { longitude }\end{array}$ \\
\hline 12069815 & Unnamed creek at Hidden Cove Road near Port Madison & 47.694 & -122.537 \\
12069820 & Unnamed creek at Madison Avenue near Port Madison & 47.686 & -122.522 \\
12069825 & Unnamed creek at Sunrise Drive near Rollingbay & 47.686 & -122.511 \\
12069828 & Unnamed creek near Wardwell Road near Manitou Beach & 47.649 & -122.529 \\
12069830 & Unnamed creek at Koura Road near Rollingbay & 47.665 & -122.530 \\
12069835 & Unnamed creek at State Hwy 305 near Manitou Beach & 47.655 & -122.524 \\
12069845 & Unnamed creek at State Hwy 305 near Winslow & 47.634 & -122.516 \\
12069850 & Unnamed creek at Winslow Way at Winslow & 47.625 & -122.516 \\
12069855 & Unnamed creek near Wyatt Way near Winslow & 47.630 & -122.542 \\
12069860 & Unnamed creek at Eagle Harbor Drive near Eagledale & 47.621 & -122.536 \\
12069865 & Unnamed creek at Country Club Road near Port Blakely & 47.597 & -122.520 \\
12069875 & Unnamed creek at Lynwood Center Road near Lynwood Center & 47.611 & -122.547 \\
12069880 & Unnamed creek at Baker Hill Road near Lynwood Center & 47.606 & -122.551 \\
12069885 & Unnamed creek at High School Road near Island Center & 47.636 & -122.557 \\
12069895 & Unnamed creek at Fletcher Bay Road near Fletcher Bay & 47.643 & -122.567 \\
12069900 & Unnamed creek at Battle Point Drive near Island Center & 47.648 & -122.566 \\
12069905 & Unnamed creek at Lovegreen Road near Manzanita & 47.672 & -122.544 \\
12069910 & Unnamed tributary at Peterson Hill Road near Manzanita & 47.674 & -122.553 \\
12069915 & Unnamed creek at Hidden Cove Road near Seabold & 47.690 & -122.553 \\
12069920 & Unnamed tributary near Peterson Hill Road near Manzanita & 47.674 & -122.553 \\
\hline
\end{tabular}


Table 2. Base flow-discharge measurements collected in 2007 and 2008, Bainbridge Island, Washington.

\begin{tabular}{|c|c|c|c|c|c|}
\hline Station No. & Date & $\begin{array}{l}\text { Discharge, in cubic } \\
\text { feet per second }\end{array}$ & Station No. & Date & $\begin{array}{l}\text { Discharge, in cubic } \\
\text { feet per second }\end{array}$ \\
\hline \multirow[t]{4}{*}{12069815} & May 22, 2007 & 0.24 & 12069865-Continued & September 26, 2007 & 0.06 \\
\hline & September 26, 2007 & 0.15 & & July 30, 2008 & 0.00 \\
\hline & May 28, 2008 & 0.17 & & September 23, 2008 & 0.01 \\
\hline & July 30,2008 & 0.08 & 12069875 & May 22, 2007 & 0.37 \\
\hline & July 24, 2007 & 0.01 & & May 27, 2008 & 0.15 \\
\hline & September 26, 2007 & 0.00 & & July 30,2008 & 0.00 \\
\hline & May 28, 2008 & 0.01 & & September 23, 2008 & 0.14 \\
\hline & July 29,2008 & 0.00 & & October 7, 2008 & 0.12 \\
\hline & August 21, 2008 & 0.00 & 12069880 & May 22, 2007 & 0.38 \\
\hline \multirow[t]{2}{*}{12069825} & May 24, 2007 & 0.16 & & July 25, 2007 & 0.10 \\
\hline & September 21, 2008 & 0.09 & & October 7, 2008 & 0.15 \\
\hline \multirow[t]{4}{*}{12069828} & September 26, 2007 & 0.12 & 12069885 & May 22, 2007 & 0.38 \\
\hline & May 29, 2008 & 0.14 & & July 24, 2007 & 0.22 \\
\hline & July 29, 2008 & 0.057 & & September 27, 2007 & 0.23 \\
\hline & September 22, 2008 & 0.12 & & May 27, 2008 & 0.22 \\
\hline \multirow[t]{6}{*}{12069830} & May 24, 2007 & 0.02 & & July 30, 2008 & 0.00 \\
\hline & July 24,2007 & 0.00 & & September 21, 2008 & 0.21 \\
\hline & September 26, 2007 & 0.00 & 12069895 & May 22, 2007 & 0.52 \\
\hline & May 28, 2008 & 0.00 & & July 24, 2007 & 0.25 \\
\hline & July 29, 2008 & 0.00 & & September 27, 2007 & 0.19 \\
\hline & September 22, 2008 & 0.00 & & May 27, 2008 & 0.22 \\
\hline 12069835 & May 23, 2007 & 1.05 & & July 30,2008 & 0.13 \\
\hline \multirow{3}{*}{12069845} & May 27, 2008 & 0.02 & & July 24,2007 & 0.15 \\
\hline & July 30,2008 & 0.72 & & September 26, 2007 & 0.11 \\
\hline & September 22, 2008 & 0.00 & & May 28, 2008 & 0.19 \\
\hline \multirow[t]{6}{*}{12069850} & May 23, 2007 & 0.47 & & July 30,2008 & 0.11 \\
\hline & July 25, 2007 & 0.25 & & September 21, 2008 & 0.11 \\
\hline & September 27, 2007 & 0.26 & 12069910 & May 24, 2007 & 0.31 \\
\hline & May 29, 2008 & 0.28 & & July 24,2007 & 0.22 \\
\hline & July 29,2008 & 0.16 & & September 25, 2007 & 0.15 \\
\hline & September 23, 2008 & 0.28 & & May 28, 2008 & 0.09 \\
\hline \multirow[t]{6}{*}{12069855} & May 23, 2007 & 0.47 & & July 30,2008 & 0.00 \\
\hline & July 24, 2007 & 0.35 & & September 23, 2008 & 0.01 \\
\hline & September 26, 2007 & 0.34 & 12069915 & May 22, 2007 & 0.06 \\
\hline & May 28, 2008 & 0.32 & & July 24,2007 & 0.00 \\
\hline & July 29, 2008 & 0.32 & & September 26, 2007 & 0.00 \\
\hline & September 23, 2008 & 0.31 & & May 28, 2008 & 0.01 \\
\hline \multirow[t]{6}{*}{12069860} & May 23, 2007 & 0.06 & & July 30,2008 & 0.00 \\
\hline & July 25,2007 & 0.04 & & September 22, 2008 & 0.00 \\
\hline & September 26, 2007 & 0.00 & 12069920 & May 24, 2007 & 0.11 \\
\hline & May 27, 2008 & 0.04 & & July 24,2007 & 0.02 \\
\hline & July 30, 2008 & 0.02 & & September 26, 2007 & 0.00 \\
\hline & September 24, 2008 & 0.03 & & May 28, 2008 & 0.40 \\
\hline \multirow[t]{2}{*}{12069865} & May 23, 2007 & 0.15 & & July 30,2008 & 0.12 \\
\hline & July 25,2007 & 0.02 & & September 23, 2008 & 0.17 \\
\hline
\end{tabular}




\section{Conceptual Model of Bainbridge Island Groundwater System}

This section provides information on the groundwater system of Bainbridge Island. A brief geologic history of the area is given followed by detailed descriptions of the hydrogeologic units. Discussions of the hydraulic properties of the units and flow of water and water-level fluctuations within the aquifers also are presented. An understanding of these characteristics is important in determining the occurrence and availability of groundwater in the watershed.

\section{Geologic History}

Many studies have contributed to the current understanding of the geologic history of the study area. The following discussion is based on Vacarro and others (1998) and Jones (1999). The reader is referred to those studies for more detailed descriptions.

The geology of Bainbridge Island is a complex mix of glacial and nonglacial deposits that subsequently have been influenced by erosion. Four glaciations and three interglaciations are recognized in the Puget lowlands. For most of the Puget lowlands, the glacial deposits of the Vashon Stade of the Frasier Glaciation, which was the last major glacial advance, are exposed at the surface.

The ice of the Vashon Stade moved out of Canada about 18,000 years ago and split into two lobes. The Puget lobe flowed south into the Puget lowland and occupied all of the lowlands and was about 3,000 ft thick near Seattle and about $6,000 \mathrm{ft}$ thick near the United States-Canada border. The glacier began retreating about 14,500 years ago.

Three types of deposits are typically associated with continental glaciation: advance outwash, till, and recessional outwash. As the glacier flowed south, streams and melting ice at the front of the glacier deposited sediments known as advance outwash. Advance outwash units typically are coarse grained and make good aquifers. As the glacier continued its advance, the advance outwash was covered with glacial till. Glacial till consists of unsorted rocks that range in size from clay to boulders that are picked up by the bottom and sides of the advancing glacier. Till is considered to be a confining unit due to its compaction and resulting poor permeability from the pressure of the thousands of feet of overlying ice. As the glacier began to melt and retreat, streams emanating from the glacier deposited recessional outwash over the top of the till. Like the advance outwash, recessional outwash is coarse grained and typically forms aquifer units.

Following the glaciation, erosion has been the dominant geomorphic process affecting Bainbridge Island. Alluvial sediments, typically sands and gravels, have been deposited by streams in valleys and marsh deposits formed in low-lying poorly drained areas.
The Island is bisected by a major fault zone running eastwest just south of Eagle Harbor. On the southern side of the fault zone, Tertiary sedimentary bedrock is either exposed at the surface or overlain by shallow glacial deposits (Haugerud, 2005). The bedrock unit consists of sandstone, siltstone, claystone, and conglomerate. On the northern side of the fault zone, thick deposits of unconsolidated Pleistocene-age sediments cover the unit.

\section{Hydrogeologic Framework}

The hydrogeologic framework describes the boundaries and lithology of the hydrogeologic units (aquifers and confining units) in the study area. This framework is described by a map of the surficial hydrogeologic units and cross sections of the subsurface (fig. 8), and maps of areal extent and thickness of the hydrogeologic units (figs. 9-17). Drillers' logs of wells containing descriptions of lithology were the primary source of information. Much of the hydrogeologic analysis was done using a geographic information system (GIS) that included spatial databases of locations and lithologic information for more than 400 wells, surficial geology (Haugerud, 2005), and LiDAR digital land-surface altitudes.

The boundaries of the hydrogeologic units were estimated by analyzing and correlating surficial geology, landsurface altitudes, and lithologic information from wells. Eight hydrogeologic units have been previously defined in Kitsap County by Kahle (1998) for SUBASE Bangor and were used in this study. This study updates the hydrogeologic maps for Bainbridge Island first presented in Dion and others (1988) and by Kato and Warren, Inc., and Robinson and Noble, Inc. (2000). Table 3 lists the hydrogeologic units used in this study and their correlation with previous studies.

The first step in the analysis was to use the previously defined hydrogeologic units and determine the top and bottom surfaces of the hydrogeologic units in more than 400 well logs by analyzing the drillers' lithologic descriptions. The horizontal extent of hydrogeologic units was then defined using the information in the geologic maps and lithologic information from the wells. Three east-west and two northsouth cross sections were constructed using lithologic information from 56 wells. The land surface altitude of the cross sections was obtained from LiDAR digital elevation data. The altitude of the top surface of each unit was then constructed by plotting the altitude of the unit surface at each well location and drawing contours of equal altitude through the data. 


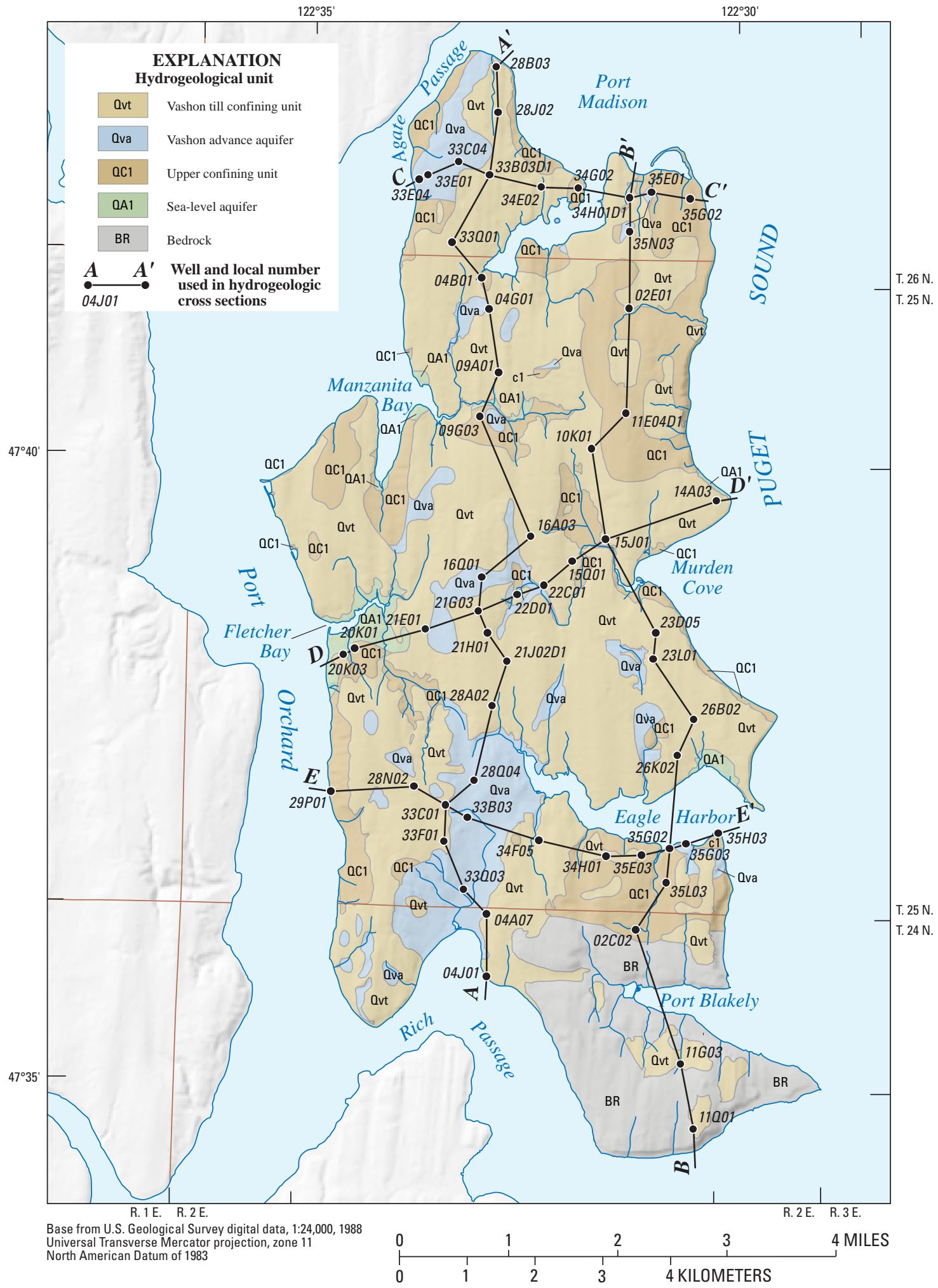

Figure 8. Surficial hydrogeologic units and cross sections, Bainbridge Island, Washington. 
Table 3. Hydrogeologic unit labels and terminology used in groundwater studies of Bainbridge Island and surrounding areas, Kitsap County, Washington.

[Symbol: -, not applicable]

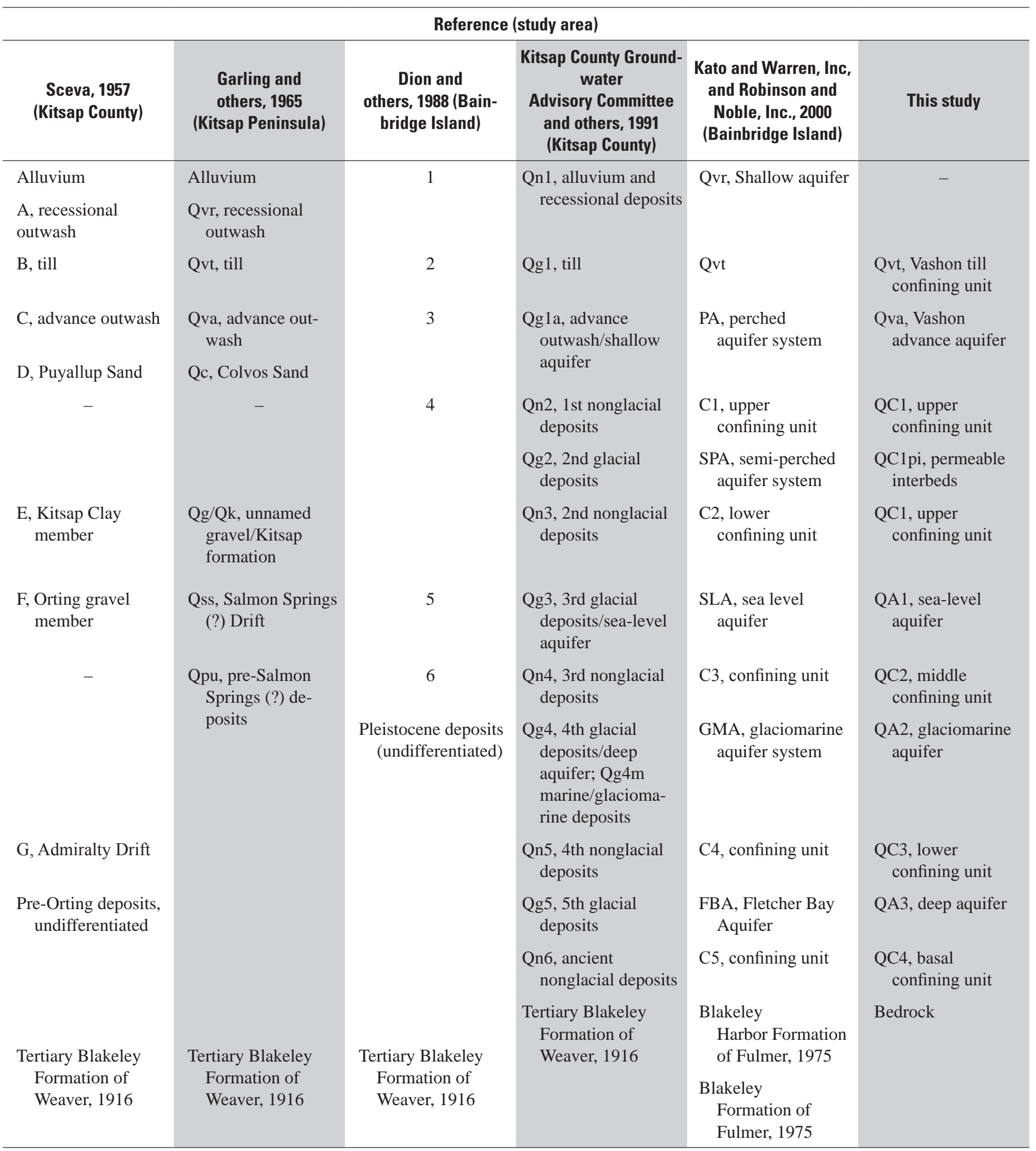




\section{Hydrogeologic Units}

The surficial geologic units from Haugerud (2005) and the deposits at depth were differentiated into aquifers and confining units based on their areal extent and general waterbearing characteristics. Generally, coarse-grained deposits have higher permeabilities than do fine-grained or poorly sorted deposits. In the Puget Sound lowland, saturated glacial outwash or coarse-grained interglacial deposits form the aquifers, whereas deposits such as till, fine-grained interglacial deposits, or glaciolacustrine deposits form the confining units. Glacial deposits generally are heterogeneous, and although a glacial aquifer may be composed primarily of sand or gravel, it locally may contain varying amounts of clay or silt. Conversely, a confining unit composed predominantly of silt or clay, may contain local lenses of coarse material.

The aquifers and confining units identified herein are referred to as hydrogeologic units because the differentiation takes into account the hydraulic and geologic characteristics of the units. Eleven hydrogeologic units were identified in the study area (from youngest to oldest and, generally highest elevation to lowest elevation):

- Vashon till confining unit (Qvt),

- Vashon advance aquifer (Qva),

- Upper confining unit (QC1),

- Permeable interbeds (QClpi), included locally within QC1,

- Sea-level aquifer (QA1),

- Middle confining unit (QC2),

- Glaciomarine aquifer (QA2),

- Lower confining unit (QC3),

- Deep aquifer (QA3),

- Basal confining unit (QC4), and

- Bedrock (BR).

Previously accepted and published nomenclature associated with the Vashon Drift was used for the upper two hydrogeologic units (Qvt and Qva). Because the deeper geologic units were more variable in terms of grain size and water-bearing characteristics, they were subdivided into hydrogeologic units using names that refer to the type of unit: aquifer (A) or confining unit (C), with a number following the letter to indicate the first (1), second (2), or third (3) aquifer or first (1), second (2), third (3), or fourth (4) confining unit below the Vashon-age deposits. This naming scheme corresponds to that of Kahle (1998).

A simplified conceptual hydrogeologic model of the groundwater system shows that the system is composed of alternating layers of permeable units (aquifers Qva, QClpi, QA1, QA2, and QA3) and less-permeable units (confining units Qvt, QC1, QC2, QC3, and QC4) overlying bedrock (BR). The hydrogeologic units are shown in detail on five hydrogeologic sections (pl. 1). Sections $A-A^{\prime}$ and $B-B^{\prime}$ are oriented south-north, and sections $C-C^{\prime}$ through $E-E^{\prime}$ are oriented west-east (fig. 8). Maps showing the areal extent and thickness of units Qvt, Qva, QC1, QClpi, QA1, QC2, QA2, QC3, and QA3 also were prepared (figs. 9-17). Thickness maps were not generated for QC4 or bedrock (shown on the hydrogeologic sections) due to a lack of data from deeppenetrating wells.

Considerable variation in occurrence and thickness of units is shown on the hydrogeologic sections (fig. 8, pl. 1). The Vashon till confining unit, Qvt, and the Vashon advance aquifer, Qva, generally are more easily recognized and correlated than older units because of their surface exposures and the numerous wells that penetrate these shallow units. However, all of the hydrogeologic units are heterogeneous and commonly discontinuous, resulting in tentative correlations in many places. Generally, the deeper the units the more tenuous the correlations. Many variations in lithology likely occur in the study area at a scale that is too small to be explicitly represented by the constructed hydrogeologic framework. However, these small-scale variations may still influence the availability and movement of groundwater. Local-scale variability in the distribution of glacial depositional facies often results in the formation of spatially discontinuous units of varying thickness. Therefore, many units in the study area are not areally contiguous throughout the study area, and unit thickness may vary considerably over short distances.

\section{Description of Hydrogeologic Units}

The youngest unit in the study area, the Vashon till confining unit (Qvt), forms a confining unit that is exposed at the land surface. The till is a very compact mix of sand and gravel in a clay matrix and is somewhat discontinuous due to erosion by streams. Some wells are open to water-bearing lenses within Qvt, although yields generally are small. The unit mantles much of the study area, particularly on hilltops. Thicknesses of Qvt vary widely, but generally are from 10 to $100 \mathrm{ft}$ (fig. 9).

The Vashon advance aquifer (Qva) consists of wellsorted sand, or sand and gravel with lenses of silt and clay that typically underlie the Qvt, but also is exposed at the surface (pl. 1), particularly in the south-central area of the Island and to the north near Agate Passage (fig. 10). This unit includes the Esperance Sand Member of the Vashon Drift mapped by Haugerud (2005). Most of the unit is unconfined, but confined groundwater conditions exist where the unit is saturated fully and is overlain by Qvt. Qva is a widely used aquifer particularly for domestic drinking water. The top of the unit ranges from sea level to an altitude of more than $300 \mathrm{ft}$. 


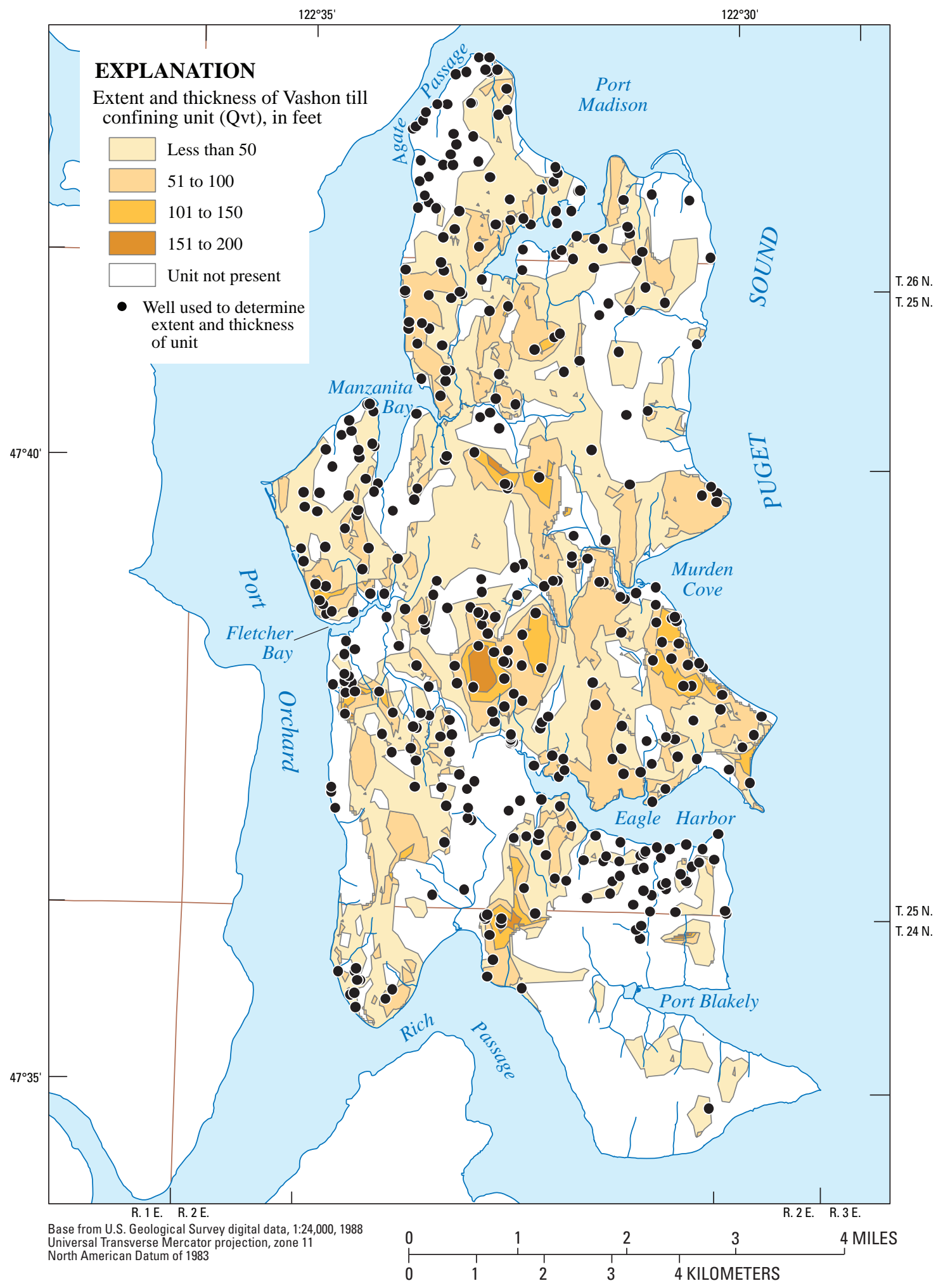

Figure 9. Extent and thickness of Vashon till confining unit (Qvt), Bainbridge Island, Washington. 


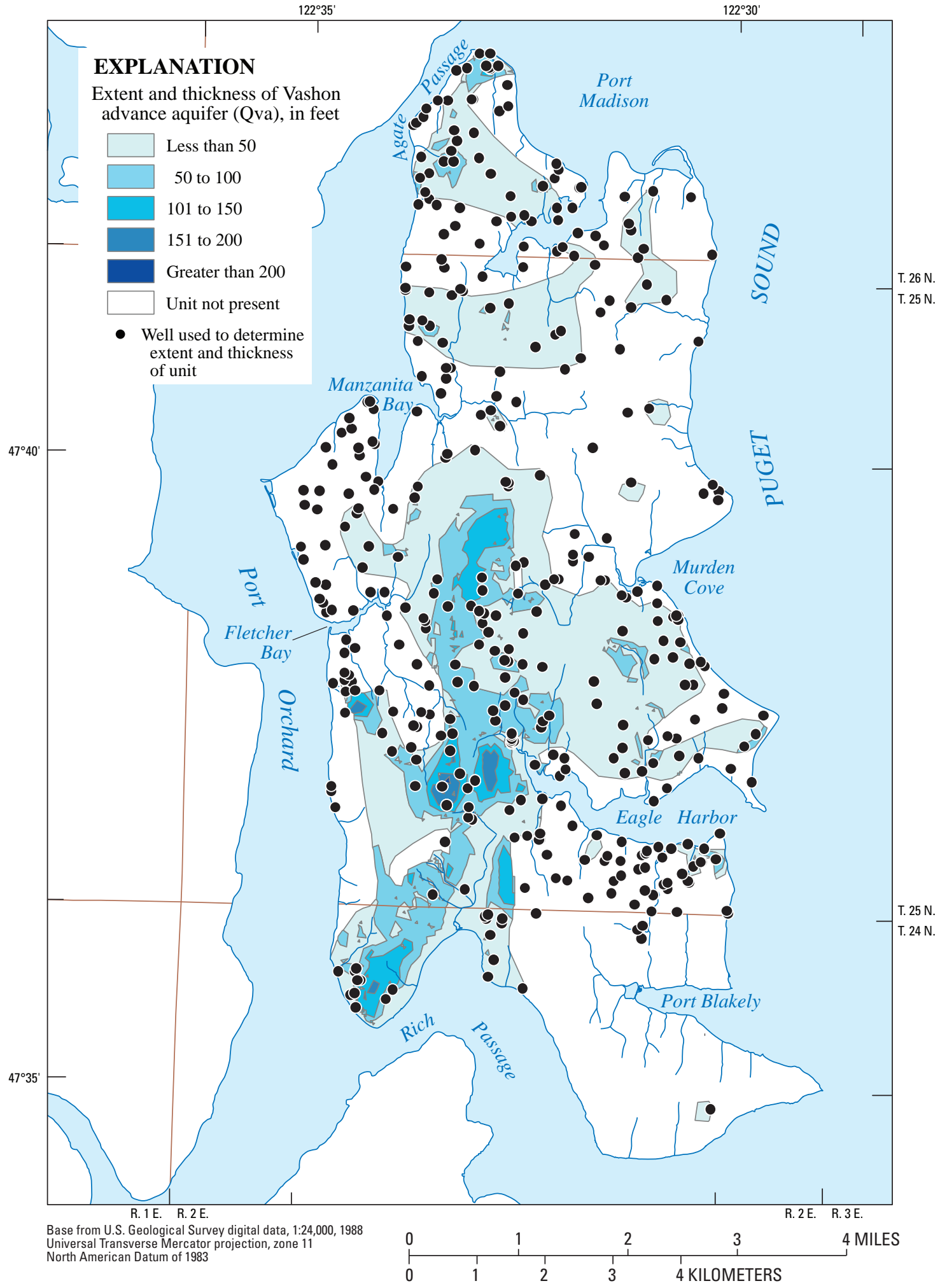

Figure 10. Extent and thickness of Vashon advance aquifer (Qva), Bainbridge Island, Washington. 
The unit generally is absent along the margins of the Island (fig. 10), likely due to erosion of the unit through time, and is not believed to be connected to the Kitsap Peninsula. The thickness of Qva commonly is from 20 to $200 \mathrm{ft}$ with most of the unit less than $100 \mathrm{ft}$ in thickness. In earlier reports, the Vashon advance aquifer has been referred to as the perched aquifer (Kato and Warren, Inc., and Robinson and Noble, Inc., 2000).

The upper confining unit (QC1) is a thick and laterally extensive low-permeability unit consisting mostly of early Vashon glaciolacustrine silt and clay (Lawton Clay) and underlying interglacial deposits of silt, sand, and gravel with numerous lenses of silt and clay or silty peat. In some areas of the study area, there are thin and discontinuous lenses of till and outwash sand. The top of QC1 ranges from more than $80 \mathrm{ft}$ below sea level to an altitude of more than $300 \mathrm{ft}$ (pl. 1). Thickness is generally from 50 to $300 \mathrm{ft}$, but exceeds $300 \mathrm{ft}$ in places, particularly in the southwest area of the Island (fig. 11). The unit is absent in the Manzanita Bay and Fletcher Bay areas.

Locally continuous and mappable zones of sand and gravel within the upper confining unit are referred to as the permeable interbeds (QClpi). These interbeds were identified where data were sufficient to recognize and correlate interbeds which generally are from 10 to $50 \mathrm{ft}$ thick. Although the permeable interbeds generally are mapped as isolated lenses of coarse-grained material (fig. 12), Kahle (1998) hypothesized that the deposits constituting the unit may be part of a complicated system of braided channels, and as such, the unit may be from sea level to more than $200 \mathrm{ft}$ above sea level (pl. 1). The permeable interbeds previously have been called the semiperched aquifer (Kato and Warren, Inc., and Robinson and Noble, Inc., 2000) and were mapped over a more substantial area of the Island. Much of the previously mapped semiperched aquifer has been shifted into the Qva unit mapped in this report (fig. 10).

The sea-level aquifer (QA1) is extensive, widely used, and mostly confined by QC1 (ig. 13). It is exposed at land surface near Fletcher Bay and Manzanita Bay and near part of Eagle Harbor. The aquifer is absent near Port Madison. QA1 consists mostly of glacial sand and gravel with silt interbeds. The top of the sea-level aquifer ranges from more than $200 \mathrm{ft}$ below sea level to slightly more than $200 \mathrm{ft}$ above sea level (pl. 1), and is believed to extend beneath Agate Passage to the Kitsap Peninsula due to the narrow and very shallow nature of the passage and the depths at which the QA1 unit occurs in this vicinity. Typical thicknesses are from 25 to $200 \mathrm{ft}$; however, thicknesses exceed $200 \mathrm{ft}$ in several places. The term "sea-level aquifer" has been used in previous groundwater studies of the Island and adjacent areas.

The middle confining unit (QC2) is a low-permeability unit consisting of interglacial sandy silty clay and glacial sand and gravel with significant amounts of silt and clay layers. As shown in figure 14, QC2 is present throughout the study area, except on the southern end of the Island where bedrock is near the surface. The unit may be absent elsewhere, but data were not sufficient to identify those areas. The top of the unit ranges from just above sea level to more than $200 \mathrm{ft}$ below sea level (pl. 1). QC2 commonly is 150-600 ft thick, but thicknesses greater than $600 \mathrm{ft}$ exist on the Island in a few locations (fig. 13). Some of the areas where QC2 is very thick occur in areas where QA2 is absent. Thus, the great thickness mapped as QC2 likely is because part of QC3 is included in the total thickness as the two units are indistinguishable.

The glaciomarine aquifer (QA2) is a confined aquifer ranging in composition from sand and gravel to silt. Shell fragments have been noted in this unit from which it derives its marine name. Few wells withdraw water from this aquifer due to its depth and generally lower permeability compared to Qva and QA1. On the basis of the rather limited well data for this unit, thicknesses range from less than 20 to more than $300 \mathrm{ft}$. The unit generally is thicker near Murden Cove as well as Agate Passage, Manzanita Bay, and along the southern end of Port Orchard. The unit is absent near Eagle Harbor, Manzanita Bay, the southern end of Agate Passage, and the southern end of the Island where bedrock is at or near the surface (fig. 15). The unit is believed to extend beneath Port Orchard because well logs indicate its presence on Bainbridge Island and the Kitsap Peninsula. Port Orchard is a very shallow water feature and it is not likely that the channel was ever carved to the depth required to erode the QA2 unit. The top of QA2 ranges from more than $500 \mathrm{ft}$ below sea level to less than $300 \mathrm{ft}$ below sea level (pl. 1).

The lower confining unit (QC3) is a low-permeability unit composed of clay and silt with some gravel and is extensive laterally. It is absent on the southern end of the Island where bedrock is at or near the surface (fig. 16). The top of the lower confining unit ranges from more than $800 \mathrm{ft}$ below sea level to slightly less than $400 \mathrm{ft}$ below sea level (pl. 1). Thickness of the unit ranges from less than $50 \mathrm{ft}$ to more than $300 \mathrm{ft}$ (fig. 16). The unit is thinnest near Murden Cove and thickest in the central and north-central areas of the Island. As was the case with QC2, some part of QC4 likely is included in the reported thickness of this unit where QA3 is absent.

The deep aquifer (QA3), or Fletcher Bay aquifer as it is known locally, is laterally extensive and confined. The aquifer is absent locally east of Fletcher Bay, south of Murden Cove and on the southern end of the Island where bedrock is at or near the surface (fig. 17). QA3 consists mostly of sand and gravel with silt interbeds. The top of the deep aquifer ranges from more than $900 \mathrm{ft}$ below sea level to slightly less than $600 \mathrm{ft}$ below sea level (pl. 1). Typical thicknesses are from 50 to $300 \mathrm{ft}$; however, an area with thicknesses greater than $300 \mathrm{ft}$ is present in the north-central area of the Island (fig. 17). As with the QA2 unit, QA3 is believed to extend beneath Port Orchard. 


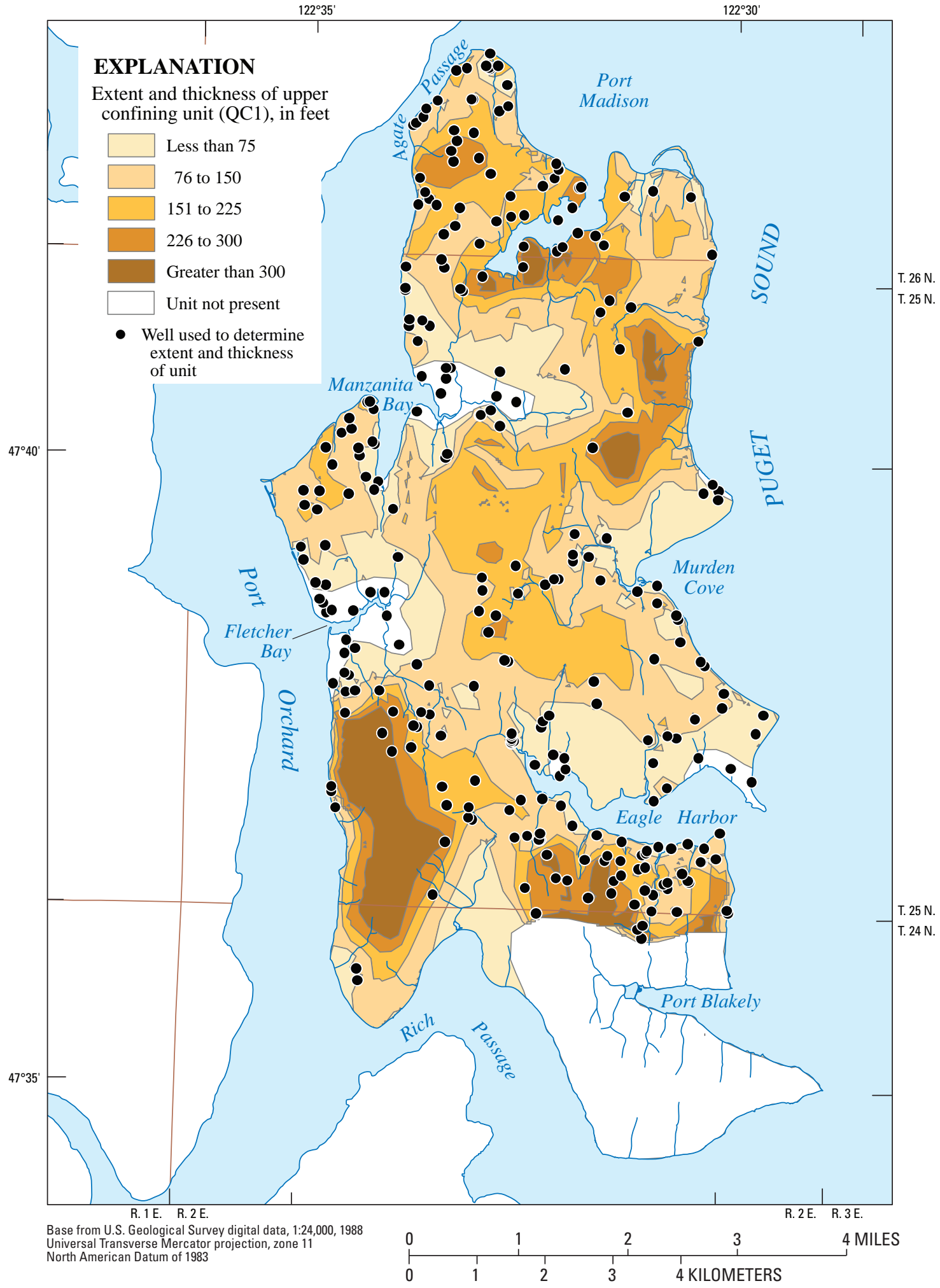

Figure 11. Extent and thickness of the upper confining unit (OC1), Bainbridge Island, Washington. 


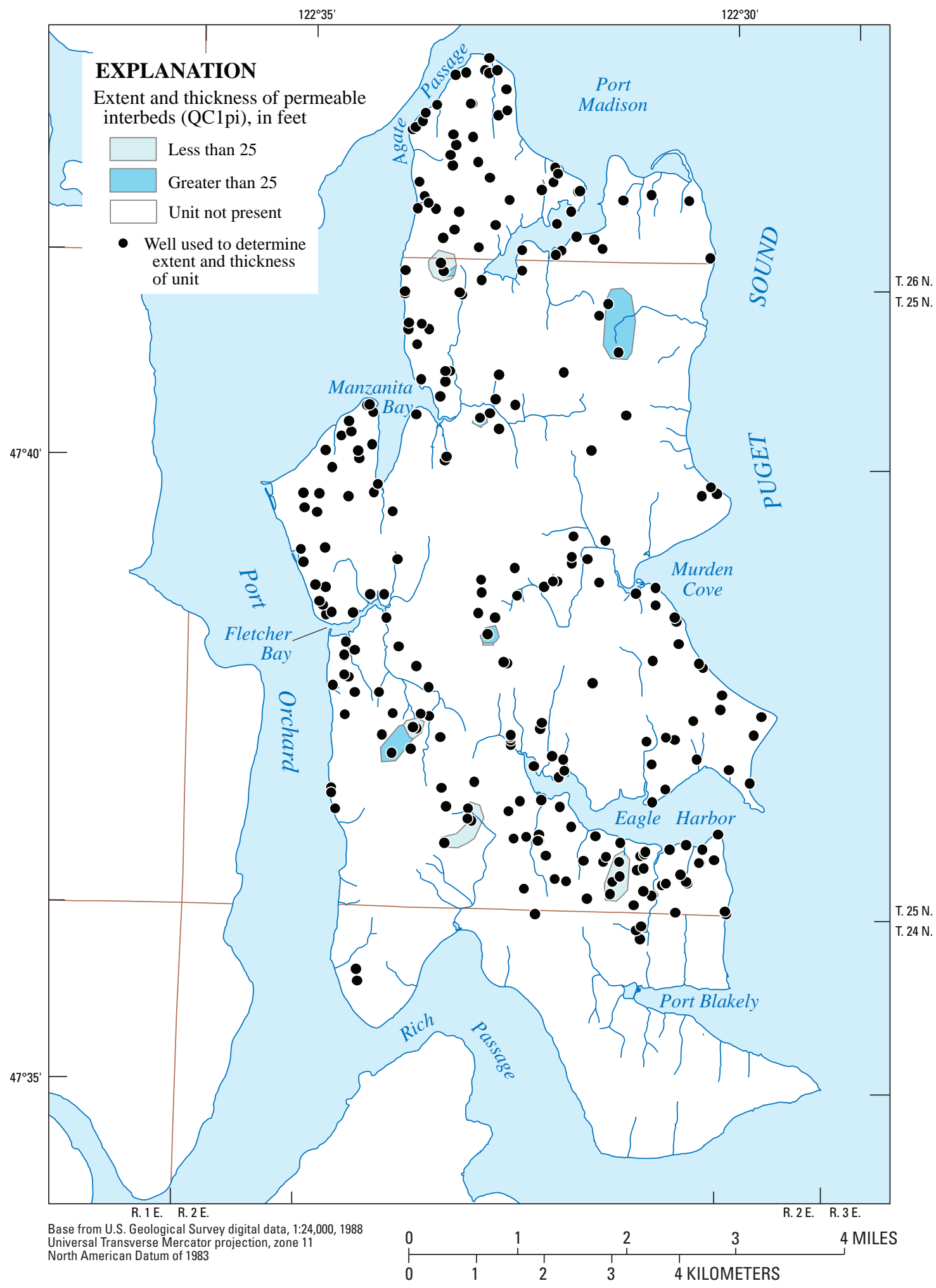

Figure 12. Extent and thickness of the permeable interbeds (0C1pi), Bainbridge Island, Washington. 


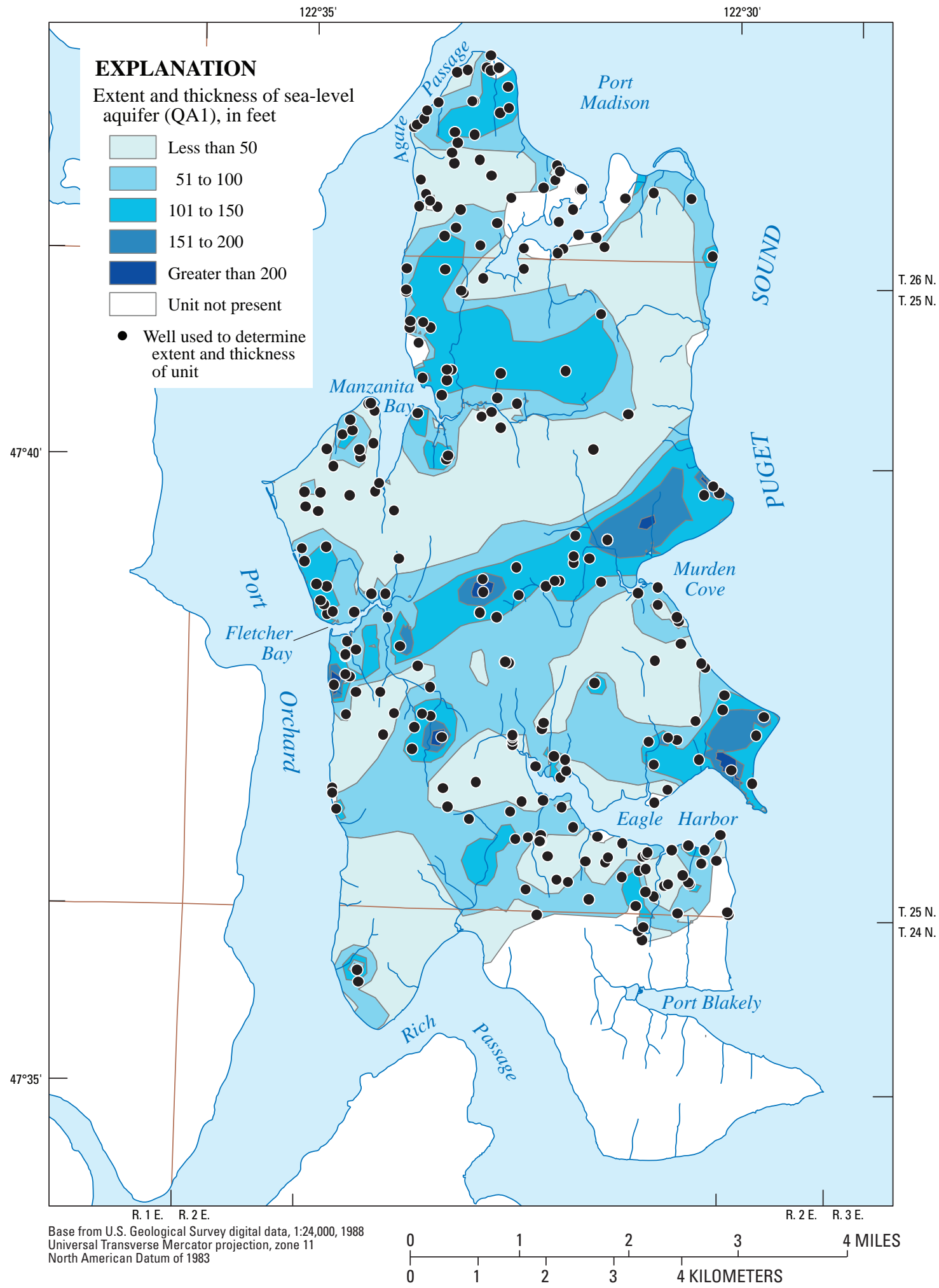

Figure 13. Extent and thickness of the sea-level aquifer (QA1), Bainbridge Island, Washington. 


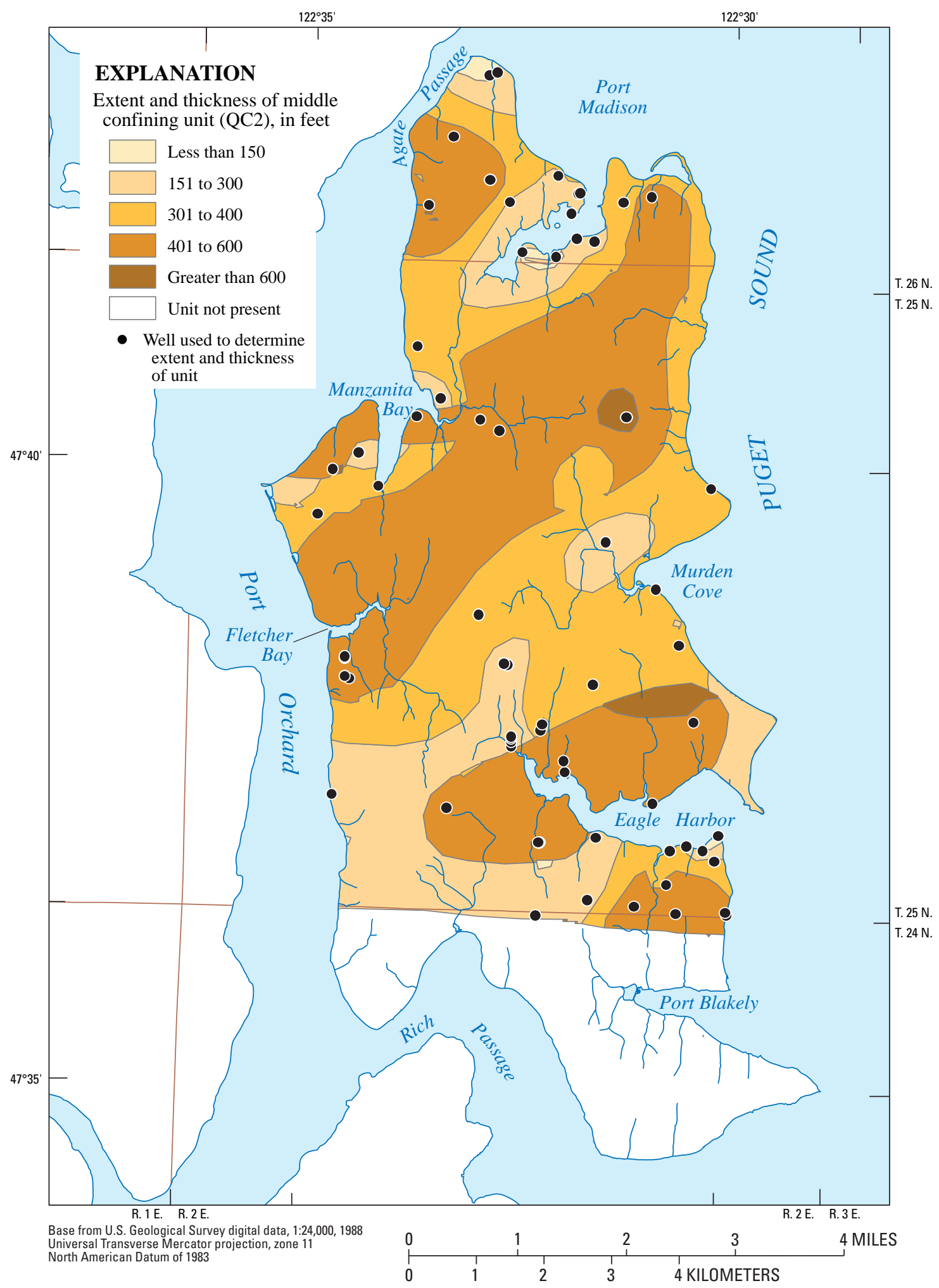

Figure 14. Extent and thickness of the middle confining unit (OC2), Bainbridge Island, Washington. 


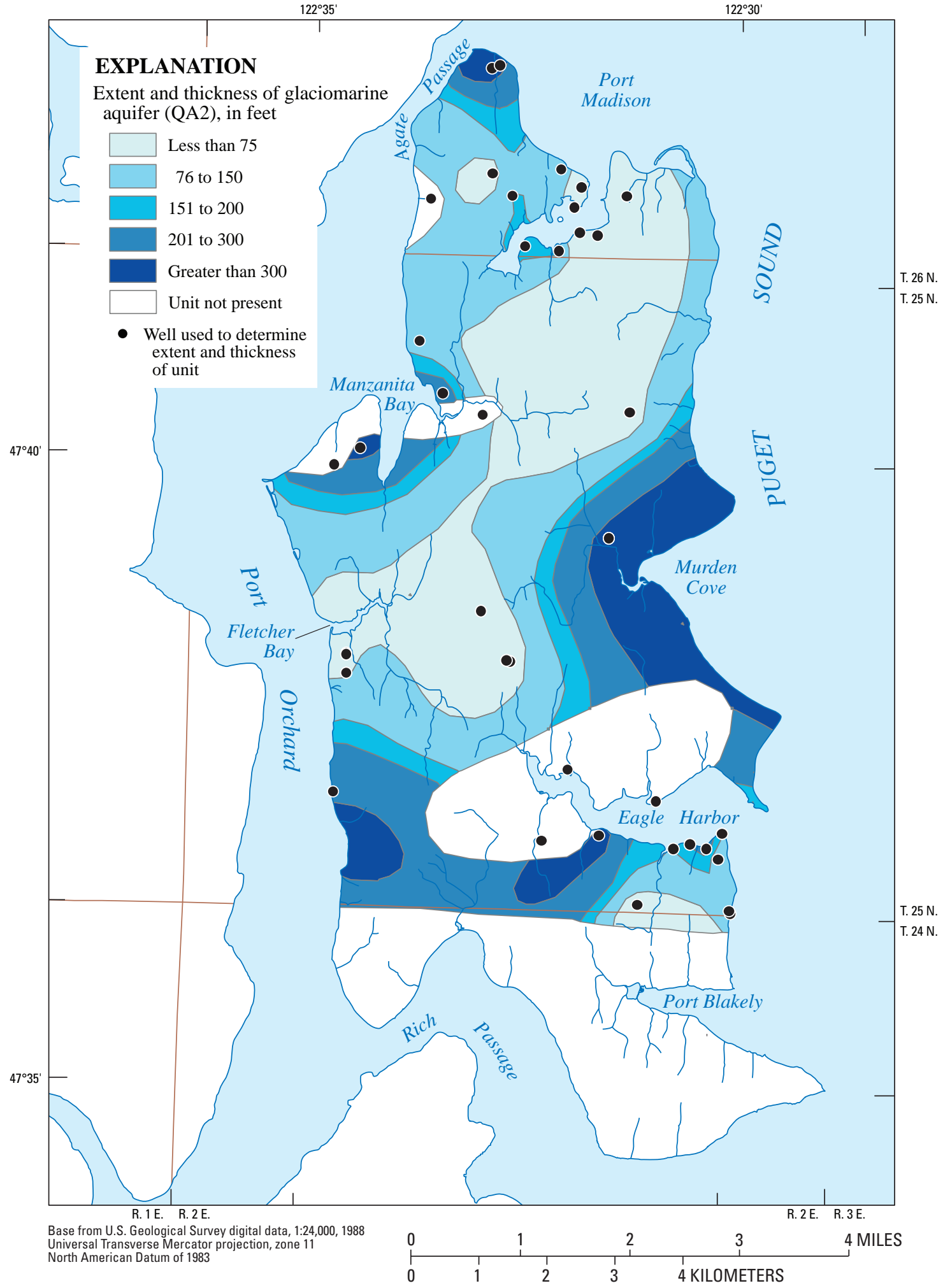

Figure 15. Extent and thickness of the glaciomarine aquifer (QA2), Bainbridge Island, Washington. 


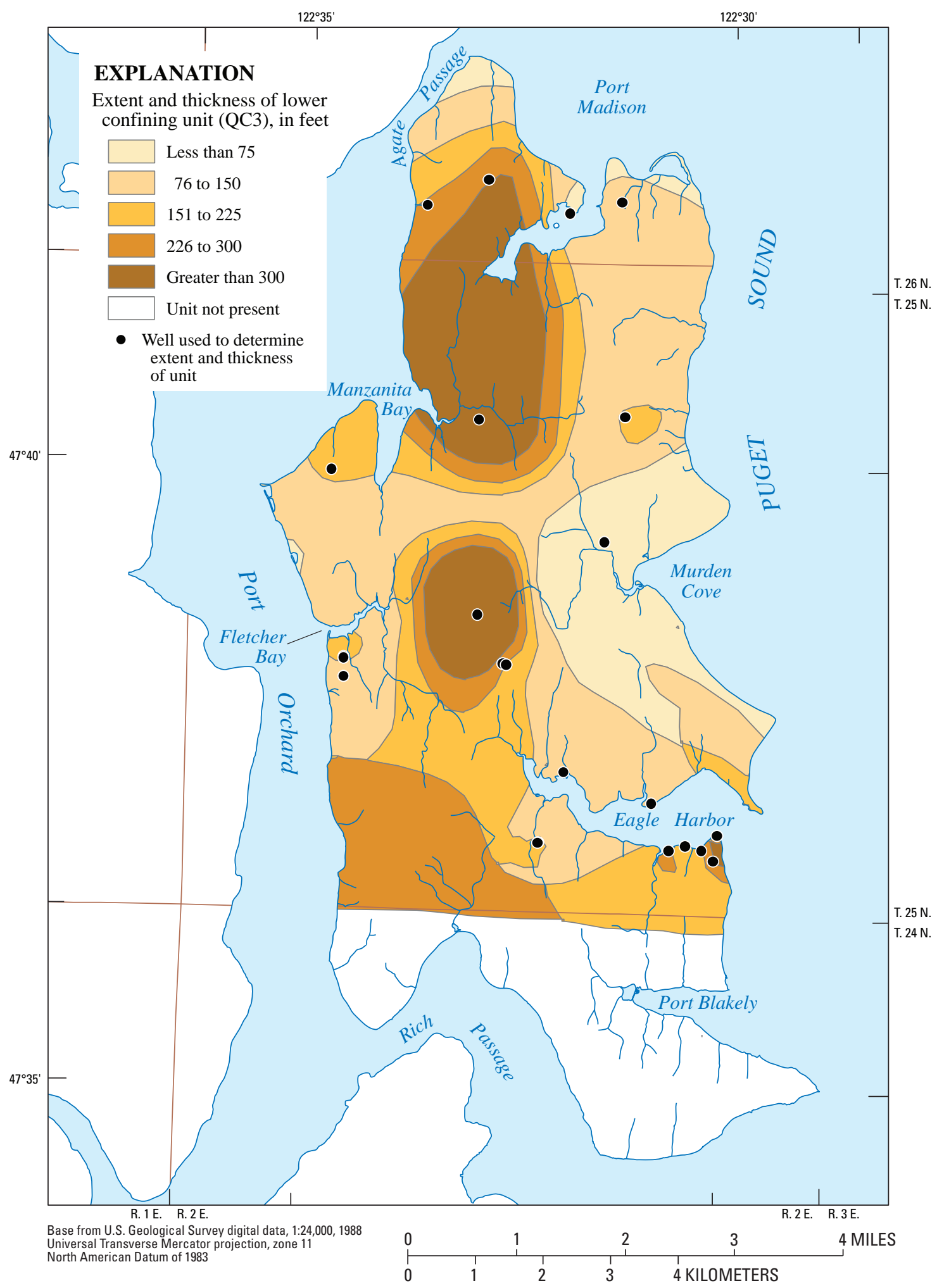

Figure 16. Extent and thickness of the lower confining unit (QC3), Bainbridge Island, Washington. 


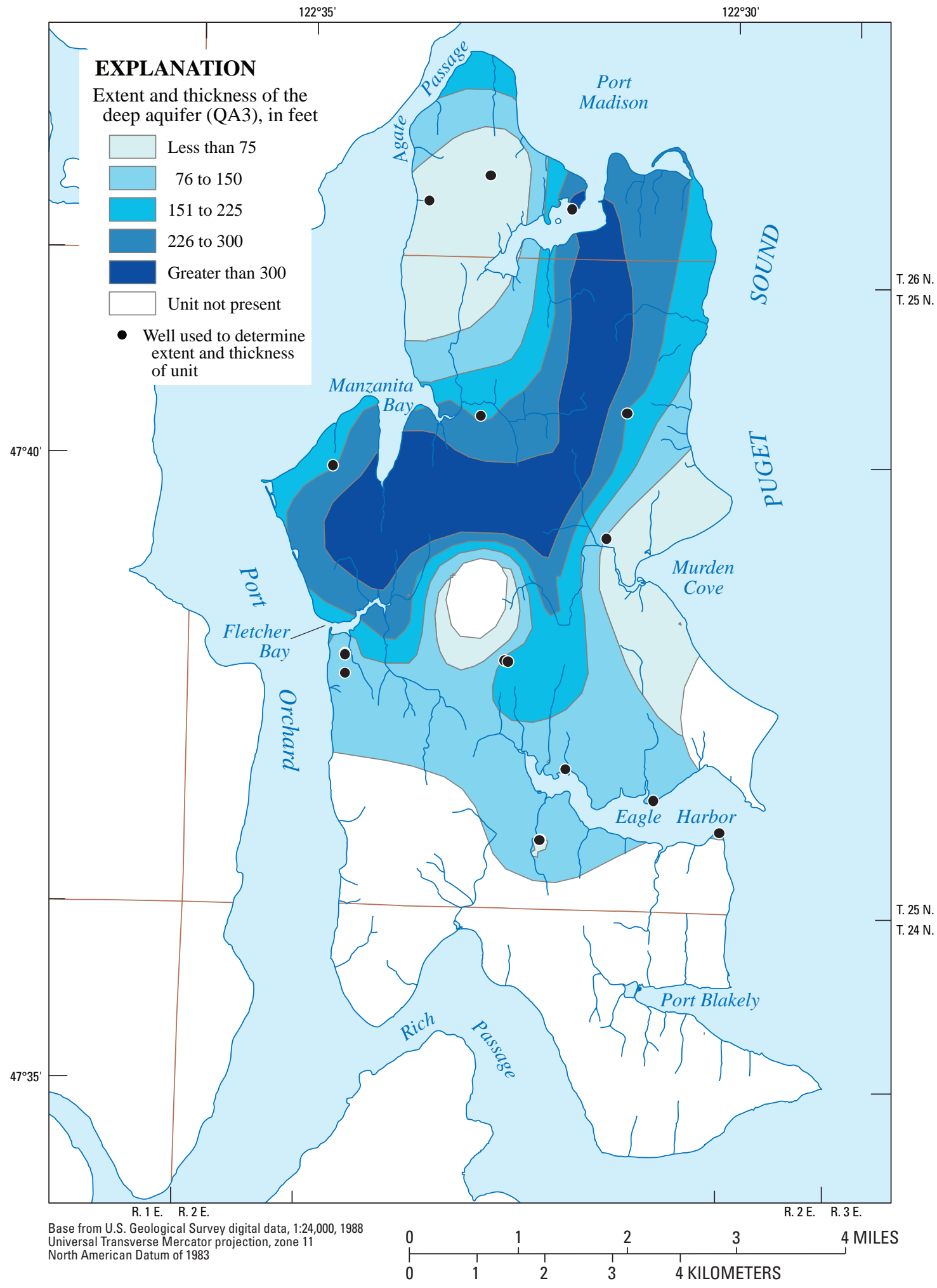

Figure 17. Extent and thickness of the deep aquifer (QA3), Bainbridge Island, Washington. 
The basal confining unit (QC4) is a low-permeability unit composed of clay and silt with some gravel and is extensive laterally. It is not present on the southern end of the Island where bedrock is at or near the surface. The top of the lower confining unit ranges from more than $800 \mathrm{ft}$ below sea level to slightly less than $400 \mathrm{ft}$ below sea level (pl. 1). Thickness of the unit is unknown.

Bedrock is present throughout the study area. It is at or near the surface on the southern end of the Island due to faulting and uplift, but north of the fault line it lies deep below the units described above. No wells penetrate to bedrock north of the fault line and the altitude of the top of the unit is unknown.

\section{Hydraulic Properties}

Horizontal hydraulic conductivities of the hydrogeologic units initially were estimated from specific-capacity data obtained from drillers' logs of the study wells (discharge rate, discharge time, drawdown, well-construction data, and lithology). The specific-capacity data were converted to hydraulic conductivity using one of two equations, depending on the method of construction of the well. Only data from wells with complete specific-capacity information were used.

For wells that had a screened or perforated interval, the modified Theis equation (Ferris and others, 1962) was used to estimate transmissivity values. This equation, solved for transmissivity using an iterative method, is

$$
T=\frac{Q}{4 \pi s} \ln \frac{2.25 T t}{r^{2} S}
$$

where

$T$ is transmissivity of the hydrogeologic unit, in square feet per day;

$Q$ is discharge, or pumping rate, of the well, in cubic feet per day;

$s$ is drawdown in the well, in feet;

$t$ is length of time the well was pumped, in days;

$r$ is radius of the well, in feet; and

$S$ is storage coefficient, dimensionless, assumed to be 0.0001 as the units generally are confined.

Assumptions for using equation 3 are that (1) aquifers are homogeneous, isotropic, and infinite in extent; (2) wells fully penetrate the aquifer; (3) flow to the well is horizontal; and (4) water is released from storage instantaneously. Leakage from adjoining units was not considered to be a factor. Although most of the assumptions are not met precisely, the field conditions in the study area approximate most of the assumptions and the calculated hydraulic conductivities are reasonable.
Horizontal hydraulic conductivity was computed using the transmissivity from equation 1 and the following equation:

$$
K_{h}=\frac{T}{b},
$$

where

$$
\begin{aligned}
& K_{h} \text { is horizontal hydraulic conductivity of the } \\
& \text { hydrogeologic unit, in feet per day; } \\
& T \text { is transmissivity, as caluclated above; and } \\
& b \text { is thickness of the hydrogeologic unit, in feet, } \\
& \text { approximated by the length of the open } \\
& \text { interval as described in the drillers' water } \\
& \text { well report. }
\end{aligned}
$$

The use of the open interval to approximate the thickness of a hydrogeologic unit assumes that the wells are open through the entire thickness of the unit, which was never the case. Nevertheless, this assumption is necessary because the equations as derived assume only horizontal flow; in a homogeneous hydrogeologic unit, horizontal flow can be measured only if a well penetrates the entire unit thickness. However, in heterogeneous and anisotropic glacial hydrogeologic units, such as those in the study area, vertical flow likely is to be much smaller than horizontal flow because the layering of the geologic materials leads to horizontal hydraulic conductivities that generally are much larger than vertical hydraulic conductivities. Thus, the assumption that the open interval represents the local thickness of the hydrogeologic unit is considered reasonable.

A second equation was used to estimate hydraulic conductivity for wells having no screen or perforations, but only an open end, and thus no vertical dimension to the opening. Bear (1979) provides an equation for hemispherical flow to an open-ended well that just penetrates the upper part of an aquifer. When modified for spherical flow to an openended well within an aquifer, the equation becomes

$$
K_{h}=\frac{Q}{4 \pi s r},
$$

where

$$
\begin{aligned}
& K_{h} \text { is horizontal hydraulic conductivity of the } \\
& \text { hydrogeologic unit, in feet per day; } \\
& Q \text { is discharge, or pumping rate of the well, } \\
& \text { in cubic feet per day; } \\
& S \text { is drawdown in the well, in feet; and } \\
& r \text { is radius of the well, in feet. }
\end{aligned}
$$


Equation 5 is based on the assumption that groundwater can flow at the same rate in all directions, and specifically that horizontal and vertical hydraulic conductivities are equal. As discussed above, this is not likely to be true for glacial material. However, the errors associated with violating this assumption are likely to be less than those resulting from using equations 3 and 4 for open-ended wells.

The median hydraulic conductivities estimated for hydrogeologic units in this study are biased toward higher values because of the nature of the statistical sample of inventoried wells. The ideal statistical sample of wells would represent all the horizontal and vertical variations of lithology and pore-size structure in the hydrogeologic units. The wells used in this study represent only the more productive parts of the units because they primarily are domestic wells that were drilled for water-supply purposes. Generally, when a driller installs a well, the depth, location, and construction of the well are determined to maximize the amount of water that can be pumped. Thus, the less productive fine-grained parts of the hydrogeologic units are bypassed until a coarse-grained productive part is found. The bias toward higher values of hydraulic conductivity is more acute for the confining units than for the aquifers.

Horizontal hydraulic conductivities were calculated for those wells with available data, and statistical summaries were prepared by hydrogeologic unit (table 4). The estimated median hydraulic conductivities for the aquifers are similar in magnitude to values reported by Freeze and Cherry (1979) for similar materials: Qva, $37 \mathrm{ft} / \mathrm{d}$; QC1pi, $13 \mathrm{ft} / \mathrm{d}$; QA1, $22 \mathrm{ft} / \mathrm{d}$; QA2, $5.4 \mathrm{ft} / \mathrm{d}$; and QA3, $26 \mathrm{ft} / \mathrm{d}$ (table 4). Estimated median hydraulic conductivities for the confining units $(4.9 \mathrm{ft} / \mathrm{d})$ and bedrock unit (2.8 ft/d) are higher than is typical for most of the material in these units because of the bias toward higher values as described in the previous paragraph.

Table 4. Summary of hydraulic-conductivity values estimated from specific-capacity data, by hydrogeologic unit, Bainbridge Island, Washington.

[Data are in feet per day]

\begin{tabular}{lclcr}
\hline Unit & $\begin{array}{c}\text { Number of } \\
\text { wells }\end{array}$ & Minimum & Median & Maximum \\
\hline Qva & 90 & 0.70 & 37 & 13,000 \\
QC1pi & 7 & 7.4 & 13 & 750 \\
QA1 & 159 & 0.20 & 22 & 8,100 \\
QA2 & 14 & 0.18 & 5.4 & 87 \\
QA3 & 7 & 5.2 & 26 & 60 \\
BR & 4 & 0.0043 & 2.8 & 5.7 \\
QC & 3 & 3.8 & 4.9 & 7.7 \\
\hline
\end{tabular}

\section{Groundwater Movement}

The direction of groundwater movement is determined from water levels measured in wells that typically are screened in the aquifers. Groundwater moves from areas of high water-level altitudes to areas of low water-level altitudes. Groundwater levels measured during August 2007 (figs. 18-22) were used to evaluate groundwater-flow directions in aquifers on the Island. Water-level contours are based on limited water-level data and are subject to uncertainty, so the illustrated groundwater-flow directions are generalized at the regional scale and do not necessarily reflect local-flow characteristics. Water-level contours and flow directions are presented only for the Qva and QA1 aquifers (figs. 18 and 20, respectively). Water-level contours or flow directions are not shown for the QC1pi, QA2, and QA3 units because of limited water-level data (figs. 19, 21, and 22, respectively).

The Qva aquifer generally shows a radial flow pattern with flow moving from the central areas of the Island toward the shorelines (fig. 18). Water-level altitudes range from more than $300 \mathrm{ft}$ above sea level in the south-western area of the Island to near zero along the shorelines. In areas where the water levels in Qva intersect the land surface, groundwater discharges to surface-water bodies. The vertical hydraulic gradient and flow direction in the Qva aquifer generally is downwards in the interior areas of the Island and upwards along the coastline, where the groundwater discharges to Puget Sound.

The QA1 aquifer also shows a radial pattern of flow moving from the central areas of the Island towards the shorelines (fig. 20). Water-level altitudes range from more than $150 \mathrm{ft}$ above sea level in the center of the Island to near zero along the shorelines. As with the Qva aquifer, the vertical hydraulic gradient and flow direction in this aquifer generally is downwards in the interior areas of the Island and upwards along the coastline, where the groundwater discharges to Puget Sound.

\section{Recharge}

The bulk of recharge to the groundwater system is in the form of deep percolation of precipitation. Secondary recharge occurs as the result of septic-system returns. Recharge from precipitation was determined in two ways. A deep-percolation model (DPM) was developed for a small basin on the Island and regression relations were established between the DPMcalculated recharge amount, precipitation, and land use and soil types to extrapolate to the remainder of the Island. Monthly fractional drainage from the root zone discussed in Bidlake and Payne (2001) was used for the remainder of the model domain. 


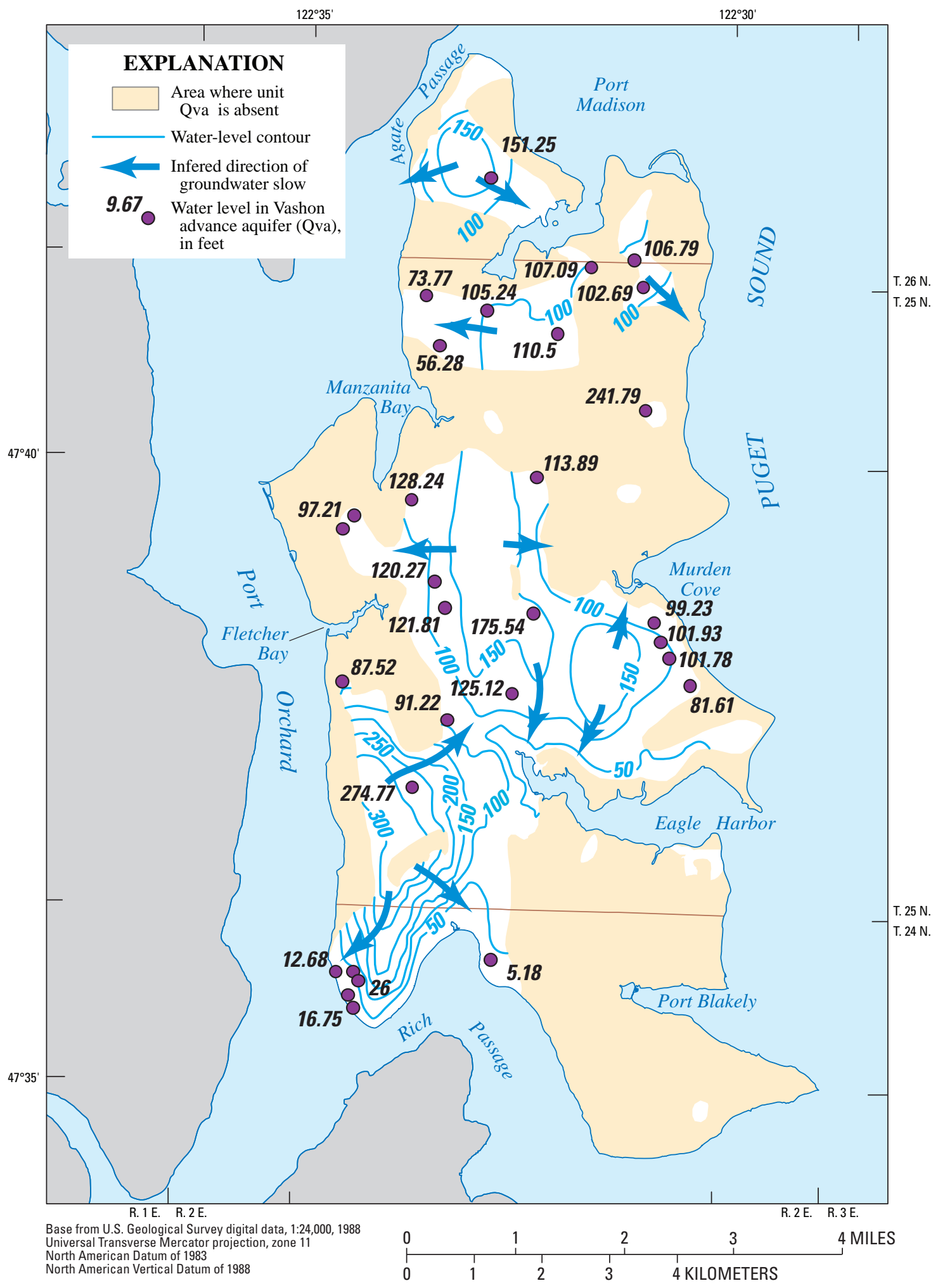

Figure 18. Water-level altitudes and direction of groundwater flow in the Vashon advance aquifer (Qva), Bainbridge Island, Washington, August 2007. 


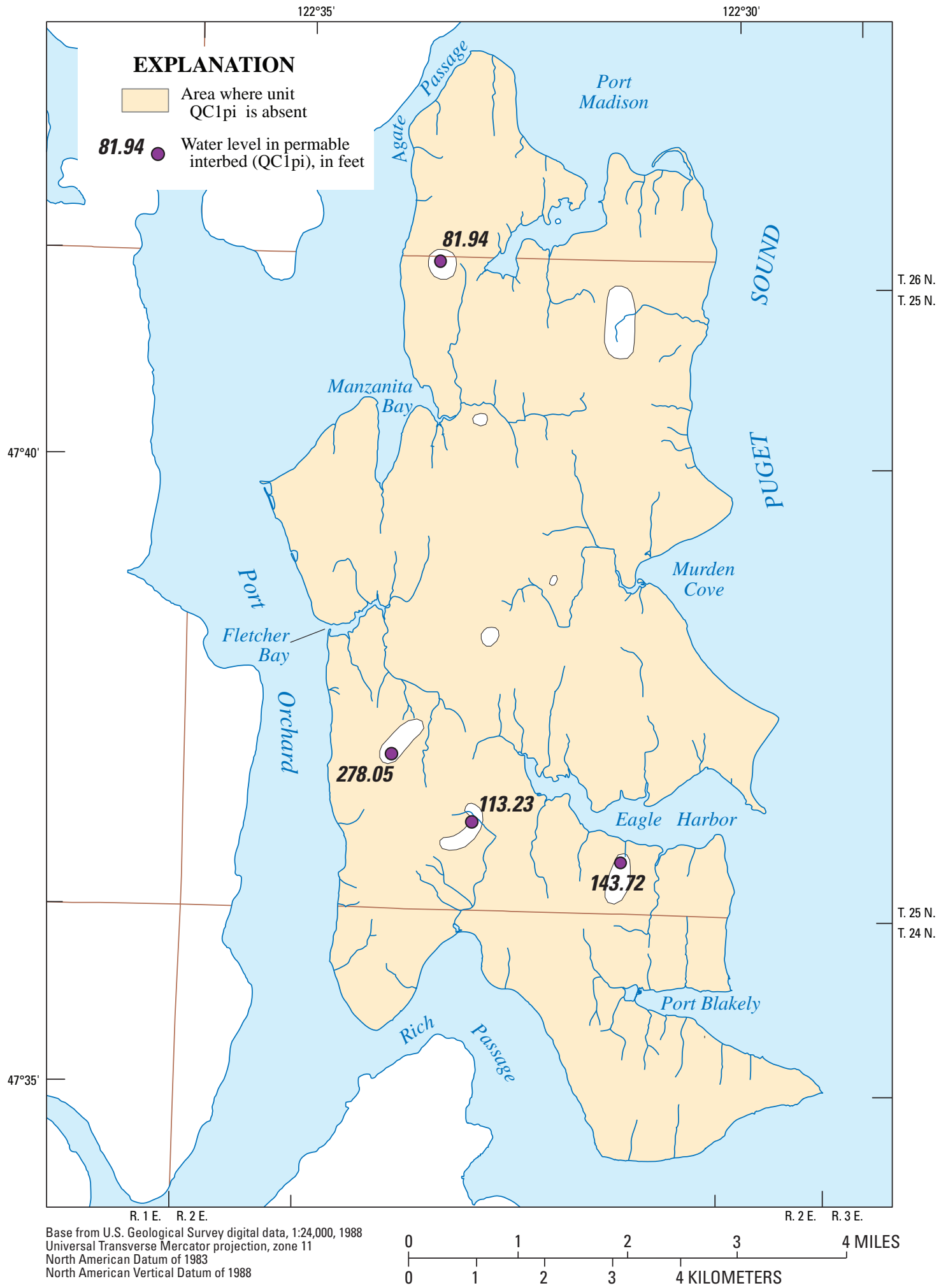

Figure 19. Water-level altitudes in the permeable interbed (OC1pi), Bainbridge Island, Washington, August 2007. 


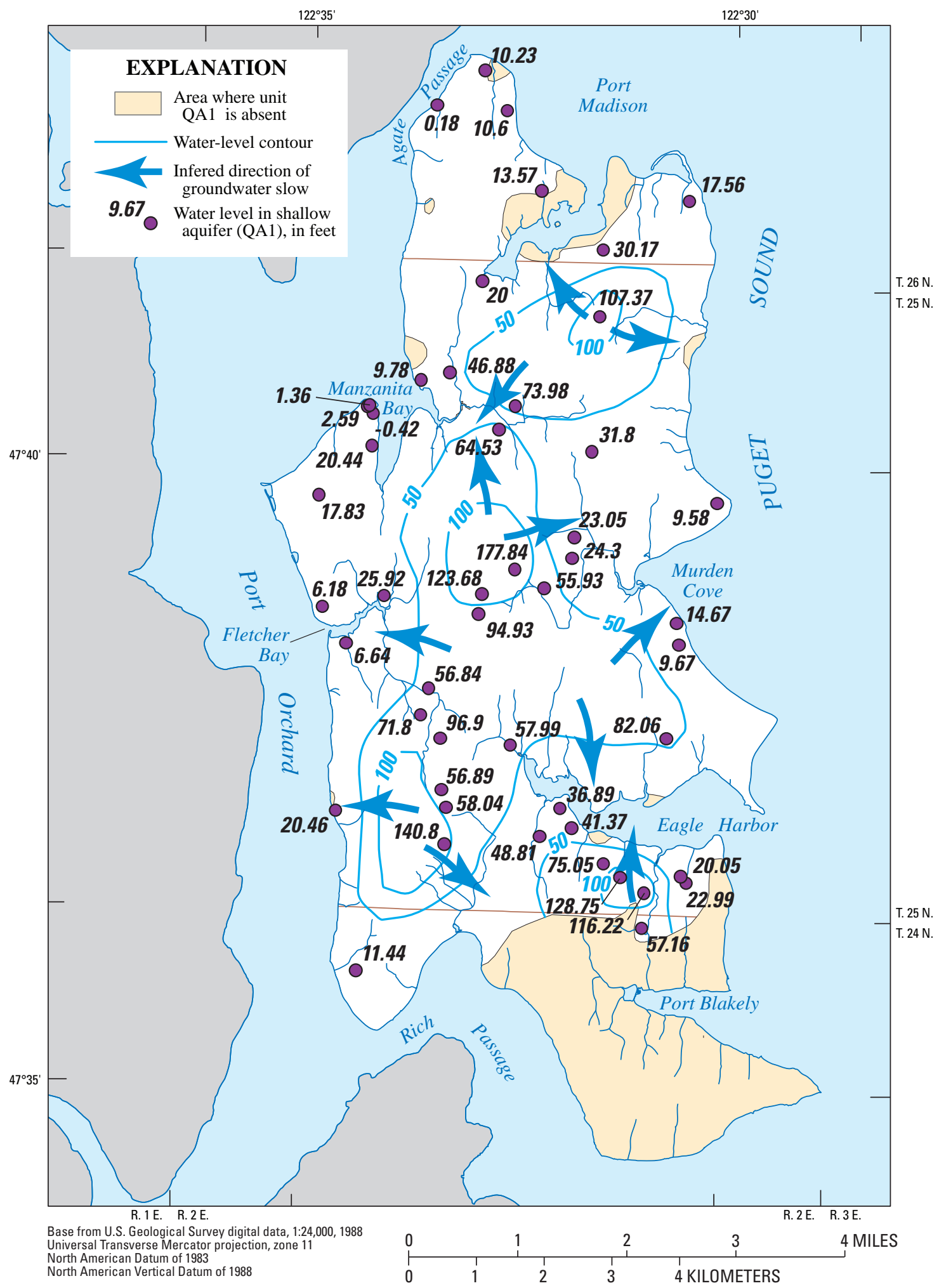

Figure 20. Water-level altitudes and direction of groundwater flow in the shallow aquifer (QA1), Bainbridge Island, Washington, August 2007. 


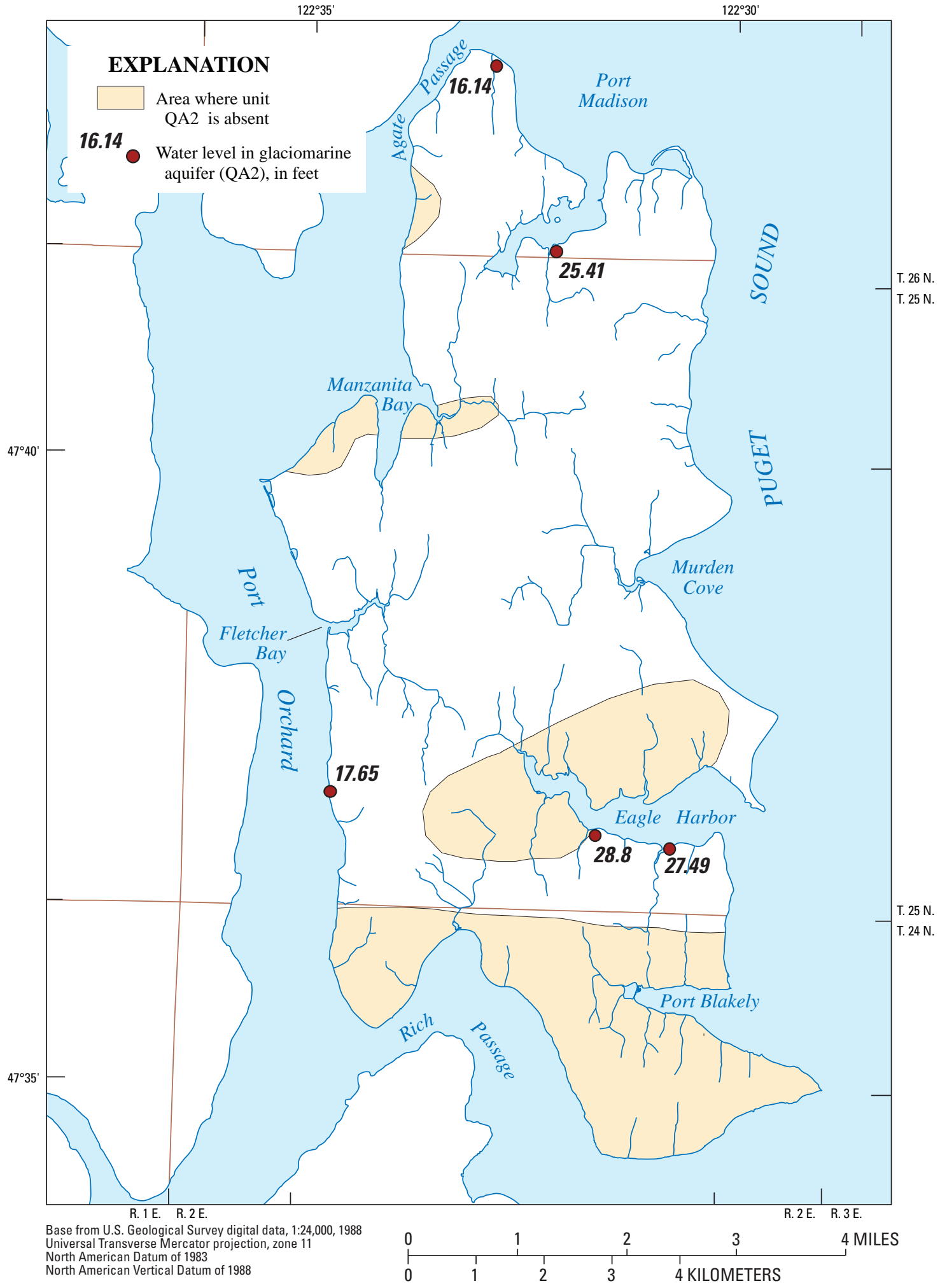

Figure 21. Water-level altitudes in the glaciomarine aquifer $(\mathrm{QA} 2)$, Bainbridge Island, Washington, August 2007. 


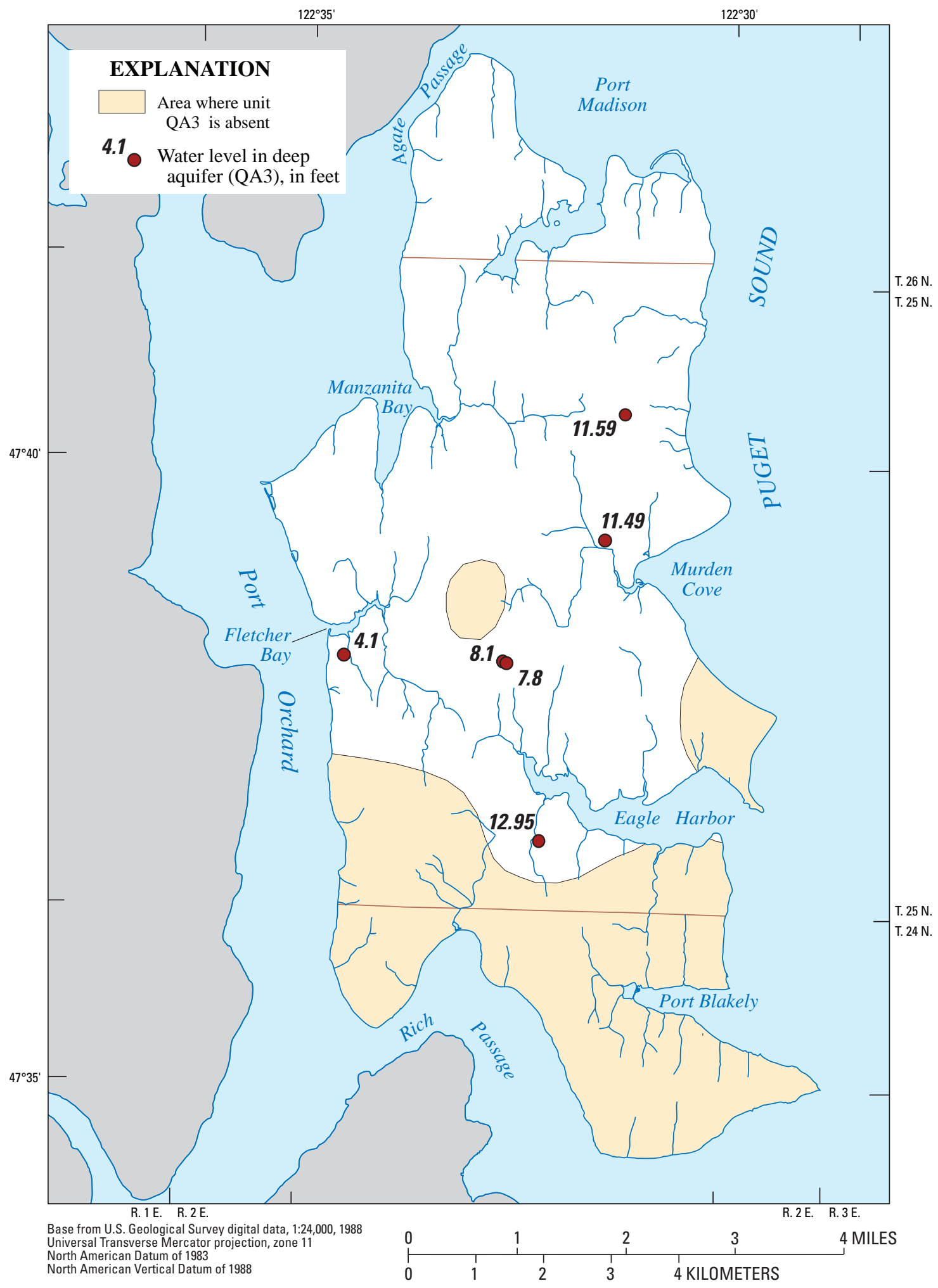

Figure 22. Water-level altitudes in the deep aquifer (OA3), Bainbridge Island, Washington, August 2007. 


\section{Deep-Percolation Model}

The drainage basin for site 12069895 (locally known as Springbrook Creek; fig. 7), covers $1.18 \mathrm{mi}^{2}$, was selected for application of a DPM to estimate groundwater recharge from precipitation. The DPM uses a daily, near-land surface water balance to estimate recharge. DPM originally was developed for eastern Washington (Bauer and Vaccaro, 1987) then modified for use in western Washington (Bauer and Mastin, 1997). DPM estimates deep percolation, the quantity of water moving from the top of foliage to the bottom of the root zone. Because it is assumed water will continue to move vertically and eventually recharge the underlying aquifer, deep percolation is equivalent to recharge. Recharge for the entire study area was estimated from a regression analysis using the results from the selected basin and the input values used in the model.

Recharge is computed as a residual, represented by the following equation (Bauer and Mastin, 1997):

$$
\begin{aligned}
R E C H & =P R C P-E V I N T-E V S O L-E V S N W-T R \\
& -R O-C H G I N T-C H G S N W-C H G S M,
\end{aligned}
$$

where

$R E C H$ is water percolating to below the rooting zone (recharge);

$P R C P$ is precipitation;

EVINT is evaporation of moisture intercepted by foliage (interception loss);

EVSOL is evaporation from bare soil;

$E V S N W$ is evaporation of snow;

$T R$ is transpiration;

$R O$ is direct runoff;

CHGINT is change in moisture stored on foilage,

CHGSNW is change in snowpack, and

CHGSM is change in soil water in the root zone.

The model computes daily fluxes of water into and out of each component on the right-hand side of the equal sign in the above equation. The area to be modeled is divided into cells of equal area and the above equation is applied to each cell.

\section{Data}

Data required for the model include daily values of streamflow and base flow, minimum and maximum air temperature, and solar radiation for the modeled area, and data applied to each cell of the model include latitude and longitude, predominant soil type, predominant land cover, average altitude, geologic material beneath the soils, estimates of horizontal and vertical permeabilities of the soils, rooting depths of the predominant land-cover vegetation, and starting estimates of soil moisture. Also required for the model are locations of the stations providing precipitation, temperature, and solar-radiation data, and estimates of coefficients that may be applied to some data values to account for local conditions. Detailed descriptions of the input data are listed in Bauer and Mastin (1997).

Streamflow data for the model came from a continuousrecord streamflow-gaging station near the mouth of an unnamed creek flowing into Fletcher Bay maintained by the City of Bainbridge Island as an automated flow and rainfall station in the city's Water Quality and Flow Monitoring Program (station 12069895, fig. 7). The period of record for this station is from March 2004 to March 2009. Full years of data were available for water years 2007 through 2008, which were used for the DPM. (A water year (WY) is a 12-month period that begins October 1 and ends September 30 of the year stated.)

Streamflow was separated into components (Sloto and Crouse, 1996), corresponding to overland runoff and to base flow. The hydrograph of the base flow component was examined to determine if these values were reasonable (fig. 23).

Daily precipitation and air-temperature data were obtained from a meteorological station on the Bloedel Reserve, near the northern end of Bainbridge Island (fig. 7). Examination of the records for the station revealed periods of missing data for precipitation and temperature. Records from National Weather Service stations in Bremerton, Seattle, Everett, and Tacoma were used to estimate missing values in the Bloedel Reserve record.

Solar radiation also was recorded at the Bloedel Reserve station. As with the precipitation and temperature records, missing values existed for solar radiation. A 5-day moving average was used to fill in those missing values.

Evaporation from leaf surfaces can account for a significant loss of the precipitation available for recharge; however, no data were available to use in this study. The DPM estimates these values if none are available from daily precipitation and computed values of moisture capacity of foliage and potential evapotranspiration.

Spatial data, those assigned to each cell of the model area, included soil characteristics, land cover, land-surface characteristics, and vertical soil permeability. These data were obtained from a number of sources. Data on soils in Kitsap County, including available water capacity and thickness, were obtained from the Soil Survey Geographic (SSURGO) database, compiled by the U.S. Department of Agriculture (accessed August 2009 at http://soils.usda.gov/survey/ geography/ssurgo). Of the 30 distinct soil series found in the county, 8 are present in the modeled basin. These eight soils were combined to form four soil groups for the DPM, based on the type of geologic material underlying the soil: relatively impermeable till or clay; permeable gravel and sand outwash deposits; or impermeable, near-surface bedrock. 


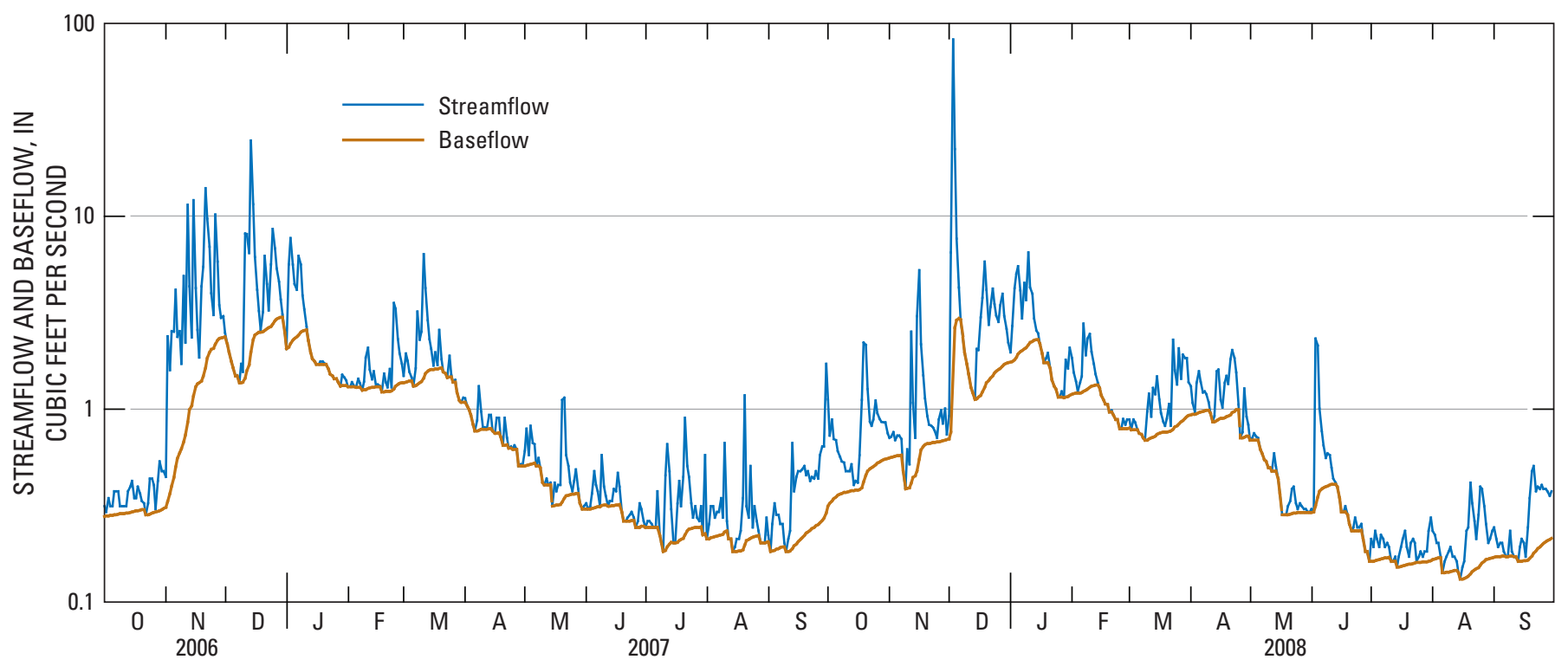

Figure 23. Streamflow at unnamed creek at Fletcher Bay Road, Bainbridge Island, Washington, 2006-08.

Land-cover data for the basin were obtained from the Multi-Resolution Land Characteristics Consortium (U.S. Department of the Interior, 2008). Ten land-cover categories listed for the basin in the dataset were grouped into 6 categories for the DPM. The DPM grouping was based on similar foliar cover or extent of impervious area, rooting depths, and seasonal growth characteristics (evergreen or deciduous plants).

Other spatial data were obtained from a DPM study done in San Juan County, Washington (Orr and others, 2002). These data include rooting depths, foliar cover of vegetation, snowmelt coefficients, and starting values for soil moisture, snowpack, and soil saturation.

\section{Deep Percolation Model Results}

The DPM was run for the 2 years (WYs 2007-08) for which complete data sets of streamflow, precipitation, and solar radiation are available. Following the initial simulation, vertical and horizontal soil permeabilities and base flow estimates were adjusted to minimize the difference between precipitation and the sum of the other water-budget components including recharge.

The average recharge estimate for each month of each year of the DPM simulation for the small drainage basin and the annual and monthly average recharge estimates for the 2-year DPM simulation are presented in table 5. Simulated recharge was 17.50 in. during WY 2007 and 13.99 in. during WY 2008 The average annual recharge for the entire study basin was 15.75 in.

Deep percolation and recharge are difficult, if not impossible, to measure directly, so there will always be a certain degree of uncertainty in any recharge estimate. One way to evaluate the uncertainty is to determine recharge by another means and compare the results. Chloride mass balance and tritium tracing are two methods of estimating recharge. The use of these methods was beyond the scope of this study, but in other studies in western Washington, results using one or both of these methods indicated the DPM provided reasonable estimates of recharge (Bauer and Mastin, 1997, Orr and others, 2002, and Sumioka and Bauer, 2003).

\section{Recharge from Precipitation}

Once the recharge was computed for the small basin using the DPM, regression relations were established between the recharge amount and precipitation, land use, and soil types. This relation was then used to calculate annual recharge for the Island for 1995-2008 using annual precipitation from PRISM climate group (accessed September 2009 at http:// prism.oregonstate.edu). Monthly recharge amounts were then estimated for the entire model domain using the monthly fractional drainage from the root zone from Bidlake and Payne (2001). 


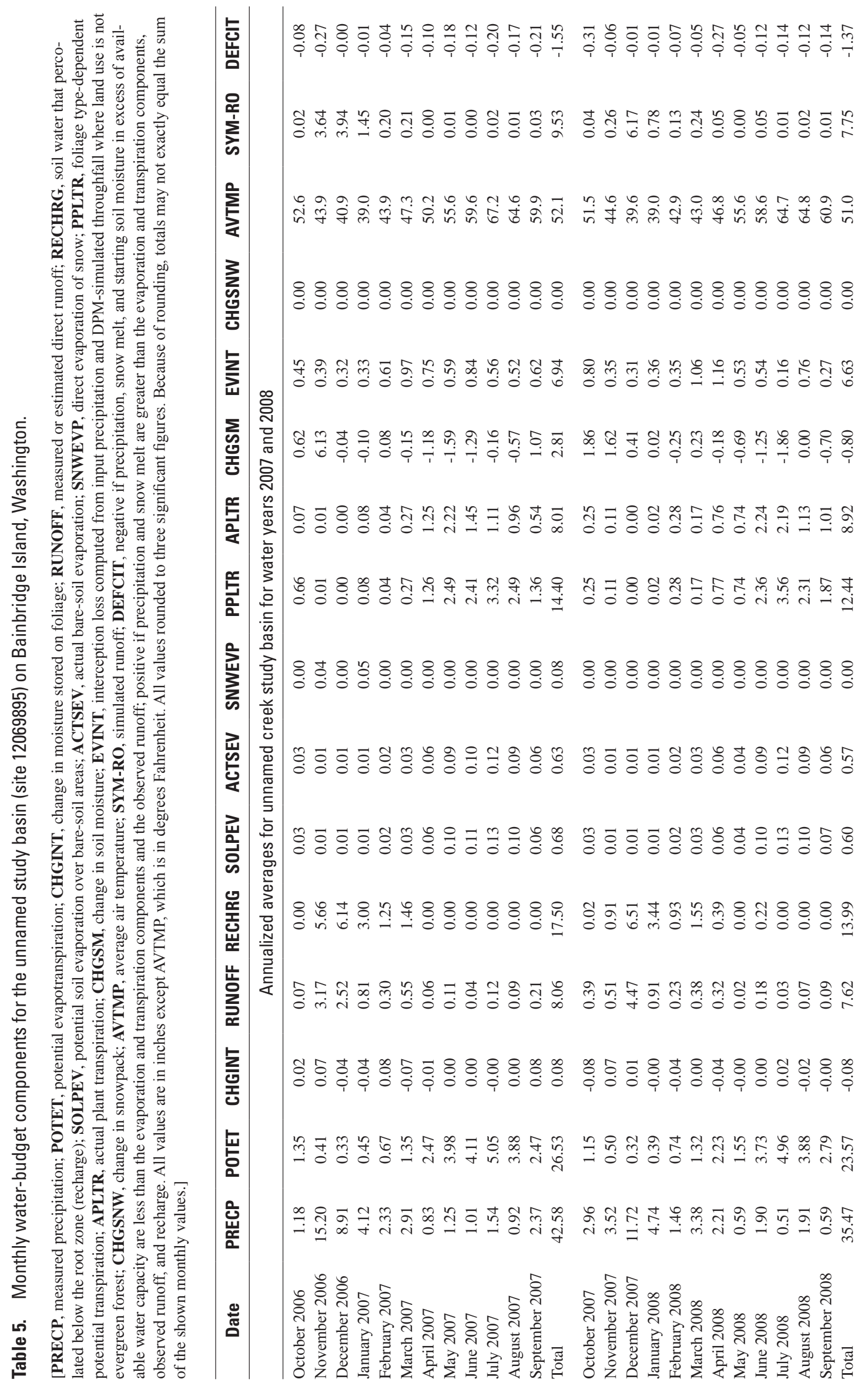




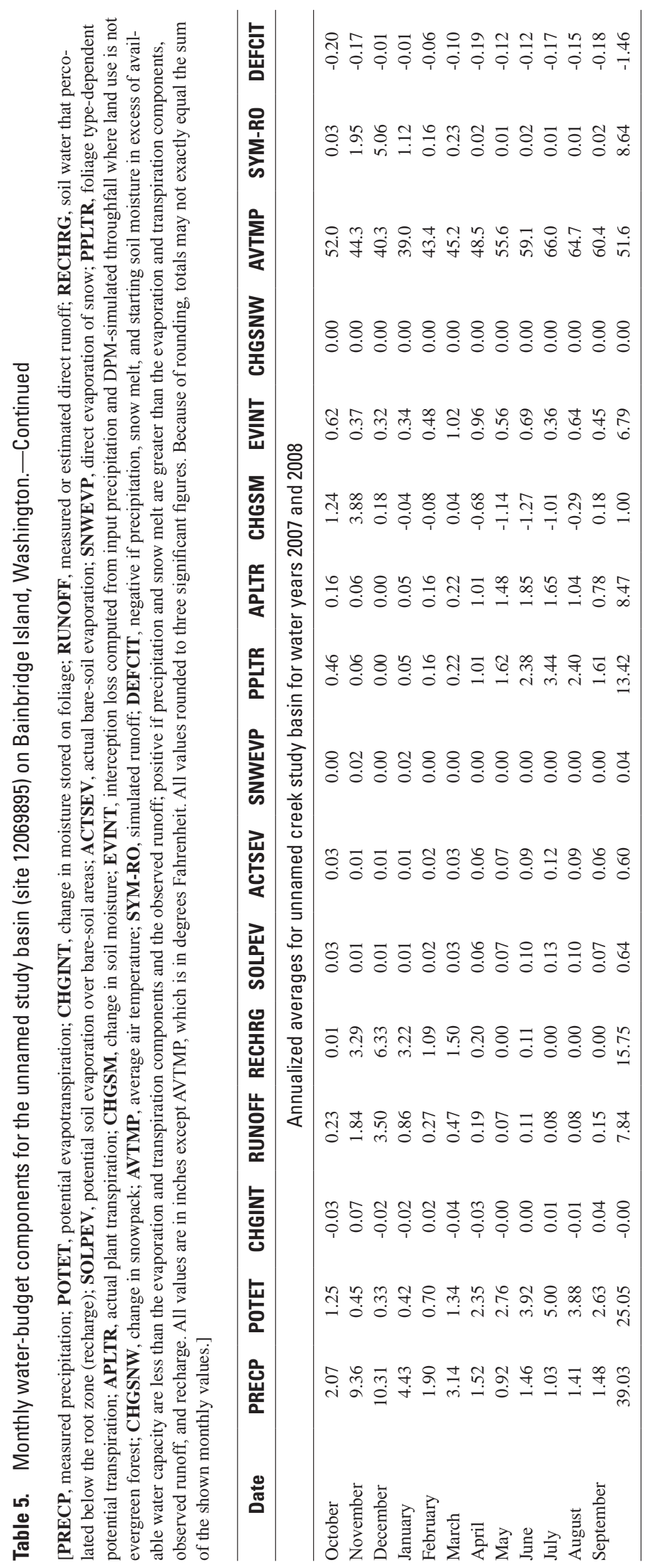


The average annual recharge estimates in this study (fig. 24) were compared to the estimates presented in the City of Bainbridge Island, Level II Assessment (Kato and Warren, Inc., and Robinson and Noble, Inc., 2000). In that assessment, three methods were used to estimate recharge: (1) a waterbudget method, (2) a regression method, and (3) an empirical method. Recharge estimates from those three methods were $13.0 \mathrm{in} / \mathrm{yr}, 16.4 \mathrm{in} / \mathrm{yr}$, and $12.9 \mathrm{in} / \mathrm{yr}$, respectively, compared to the $15.75 \mathrm{in} / \mathrm{yr}$ estimated for this study.

\section{Recharge from Septic Systems}

Secondary recharge in the study area results from septicsystem returns. Recharge from septic systems was estimated assuming that 70 percent of groundwater pumpage for publicsupply systems and for domestic wells is non-consumptive use of water that is returned to the ground in nonsewered areas (Sapik and others, 1988; Thomas and others, 1999). Pumpage from public-supply systems was apportioned between that part of the water-service area that was sewered as opposed to nonsewered. The amount of pumpage that was attributed to the nonsewered areas was then applied to the corresponding model cells at the land surface. Pumpage from domestic wells in nonsewered areas was spread over the quarter-quarter section in which the wells were located and then applied to the corresponding model cells at the land surface. Septic-system returns for 2008 are shown in figure 25. Recharge from septicsystem returns typically was 3 in/yr or less.

\section{Groundwater Withdrawals}

Groundwater is the source for all water used on the Island. The drinking water supply is divided between publicsupply water systems and domestic self-supplied systems. Groundwater-pumping rates were specified or estimated using two different methods to represent public-supply systems and domestic wells.

To estimate pumping rates for public-supply wells, locations of public-supply wells on the Island along with the population served and number of connections were obtained from Washington Department of Health (WDOH). All community Group A systems (generally 15 or more service connections) were contacted to collect monthly pumpage data for the period 1995-2008. The community Group A systems serve more than 15,700 people with about 6,600 residential connections. These public-supply systems mostly provide water for drinking and other domestic uses, but small quantities also were used for commercial and other purposes.

Pumpage data from those systems that provided usage information were used to estimate pumpage for the remaining systems. However, some systems only recently began keeping records of their pumpage, so missing data for months with no recorded data were computed as the average of all months of recorded data. For those systems that did not provide their pumpage data, an estimate was made by taking the average per person rate for a given month from those systems that provided data and multiplying it by the population reported for that system. Locations and pumpage rates for 2008 are shown in figure 26.

Domestic self-supplied water is pumped from privately owned wells for domestic purposes such as drinking water and lawn watering. To estimate the amount of domestic selfsupplied water use and Group B (less than 15 connections) systems water use, an average monthly water use per capita was applied to the population of users, which was estimated at 6,072. This population estimate came from the total Island population of 21,854 from the 2007 census estimates minus the population served by public-supply systems $(15,782)$. The average use per month per capita was assumed to be the same as the average per capita public-supply system values. Locations of domestic wells were taken from the Washington State Department of Ecology (DOE) well database. The wells in the database were located only by township, range, section, and quarter-quarter section. The database was edited to remove wells that were known to be inactive. Some wells also are present on the Island, but are not in the database because they existed prior to DOE keeping records. Individual pumping rates were calculated by taking the total monthly domestic pumpage and dividing by the approximately 1,350 domestic wells (fig. 27) on the Island.

Recreation water use included water for the two golf courses on the Island that withdraw water from the principal aquifers on the Island. Pumpage estimates for these systems were obtained directly from one of the golf courses and applied to the golf course with unknown pumpage values. The third golf course obtains water from the low permeability bedrock unit on the southern end of the Island and was not included in the estimates. 


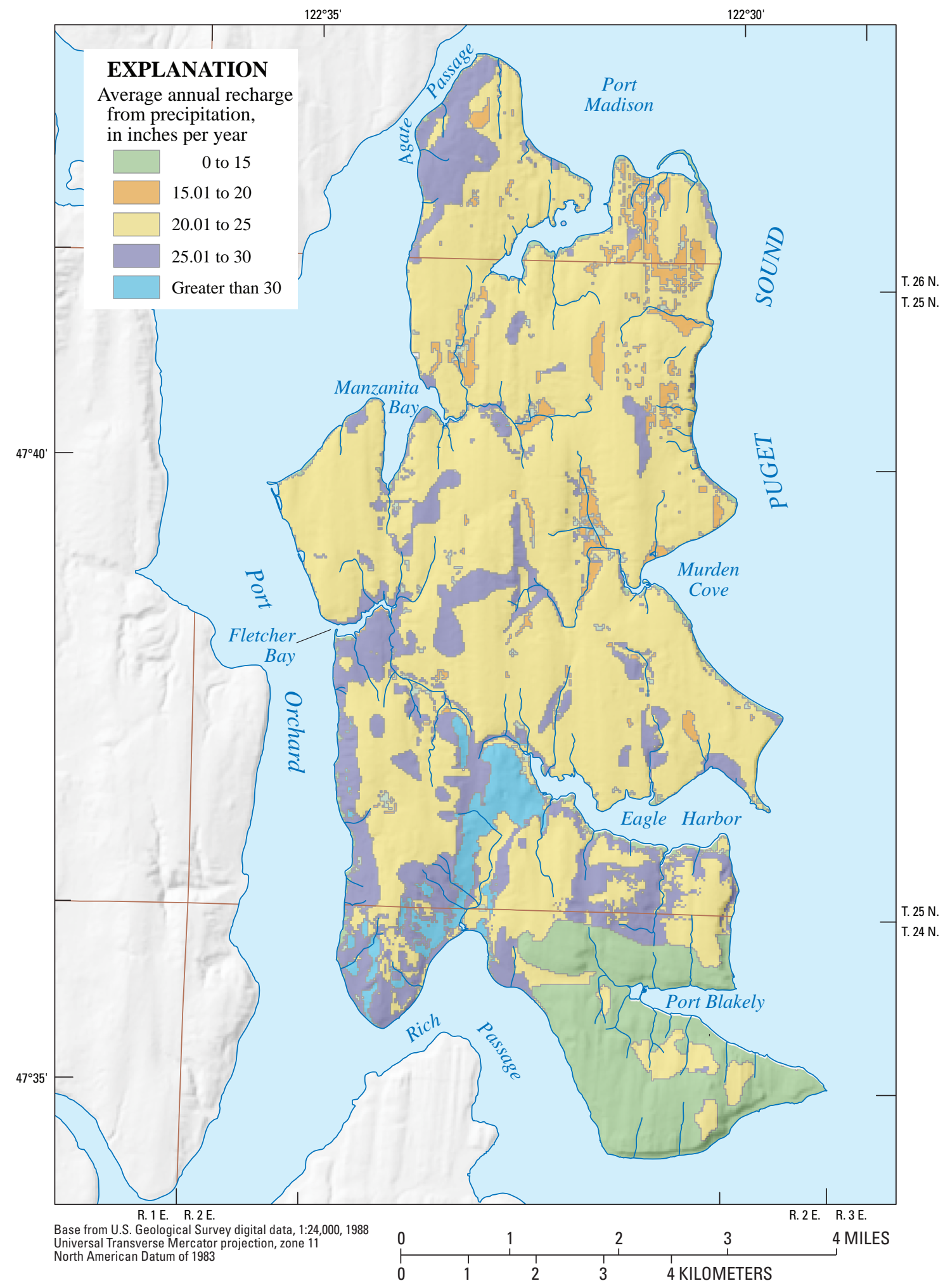

Figure 24. Average annual groundwater recharge from precipitation, Bainbridge Island, Washington. 


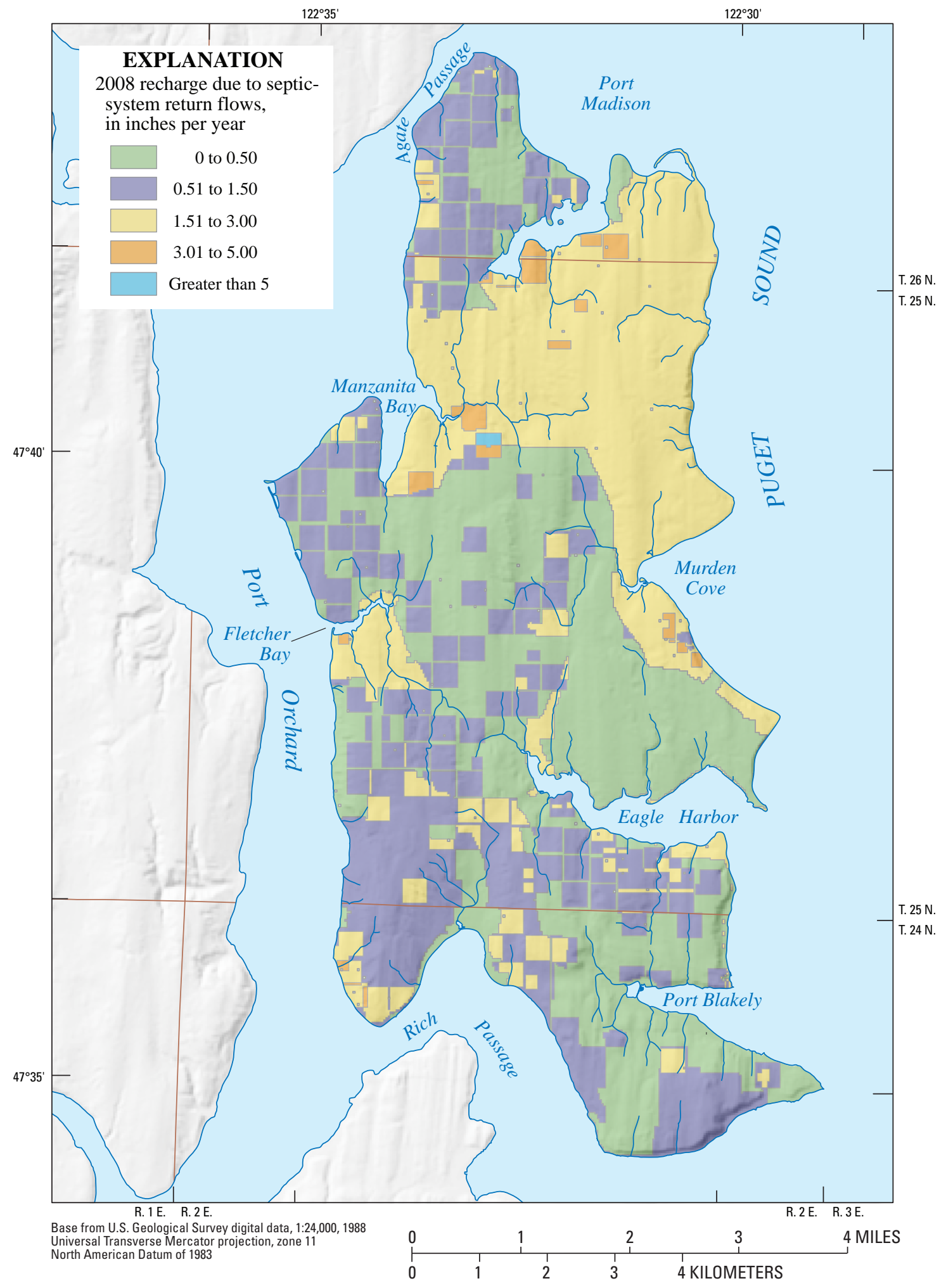

Figure 25. Distribution of recharge due to septic-system return flows, Bainbridge Island, Washington, 2008. 


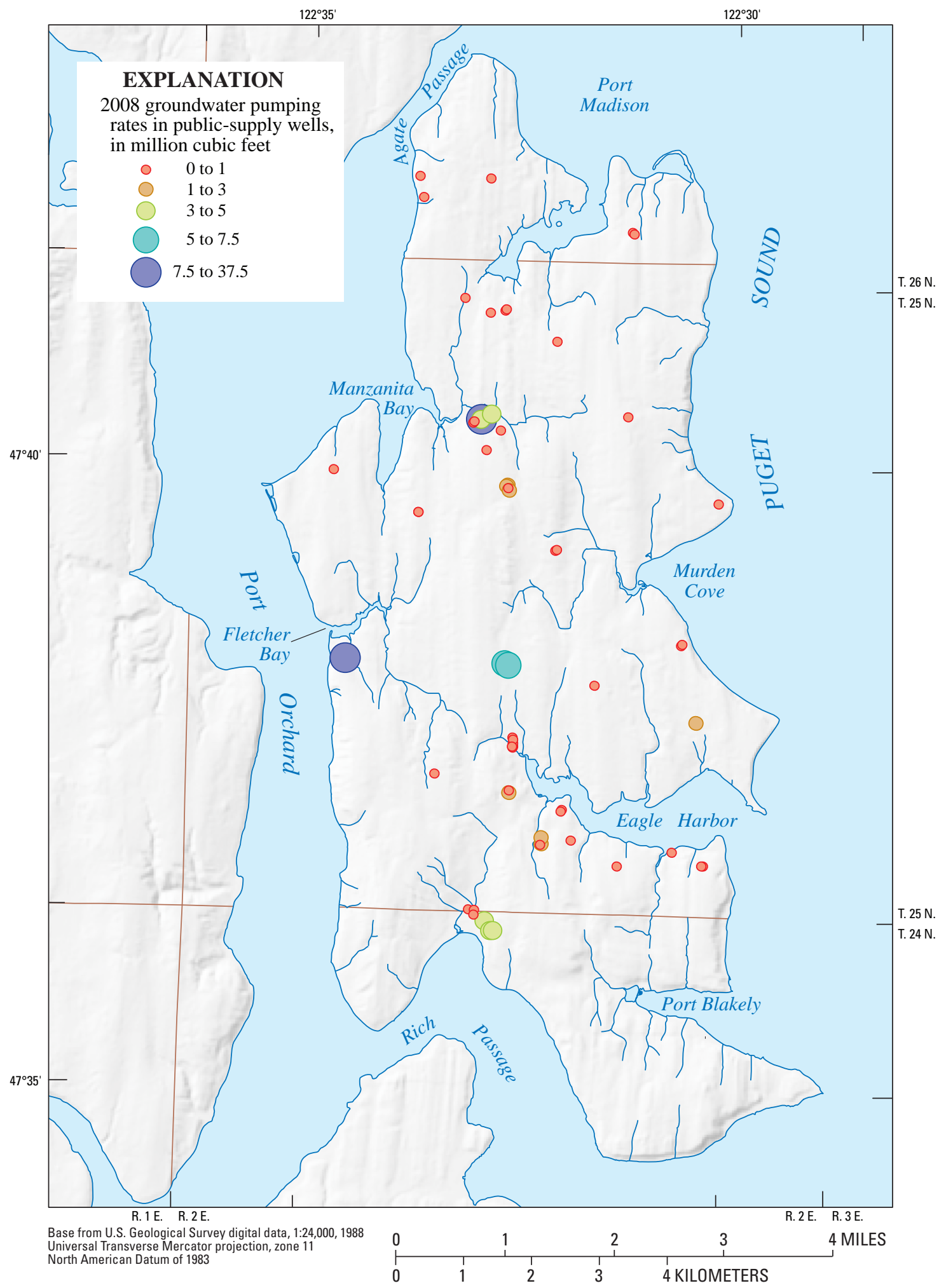

Figure 26. Location of public-supply wells and their 2008 pumping rates, Bainbridge Island, Washington. 


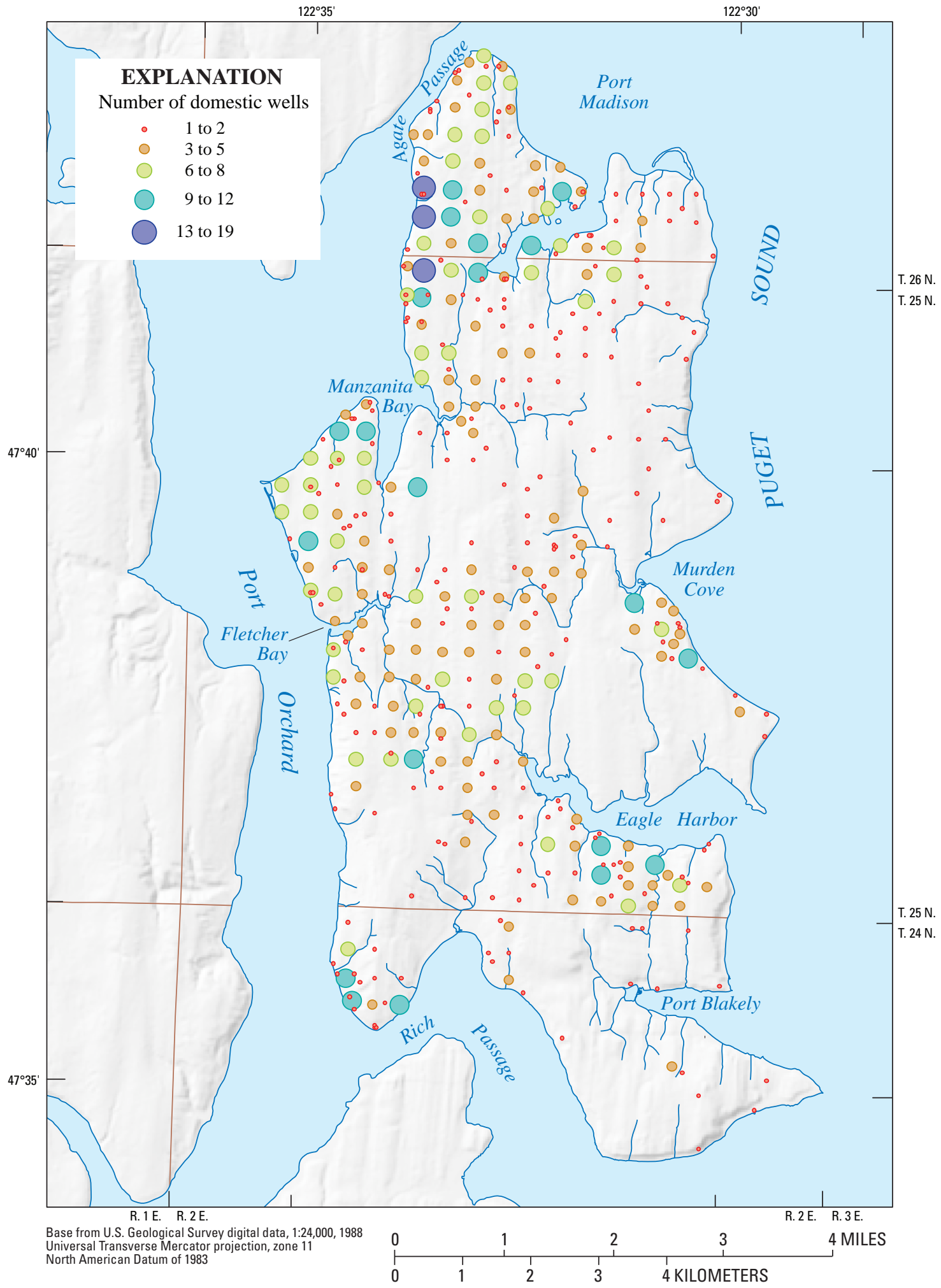

Figure 27. Location and number of domestic wells used to simulate groundwater pumping rates, Bainbridge Island, Washington. 


\section{Numerical Simulation of the Groundwater-Flow System}

Development of a numerical model allows for a detailed analysis of the movement of water through the hydrogeologic units that constitute the groundwater-flow system. Groundwater flow in the unconsolidated deposits of Bainbridge Island was simulated using the U.S. Geological Survey modular three-dimensional finite-difference groundwater-flow model, SEAWAT (Guo and Langevin, 2002; Langevin and others, 2003; Langevin and others, 2007). The SEAWAT version used (version 4; Langevin and others, 2007) couples MODFLOW-2000 (Harbaugh and others, 2000) with MT3DMS (Zheng and Wang, 1999) and allows density to be calculated as a function of one or more solute species.

\section{Model Grid and Layering}

The MODFLOW and SEAWAT programs use data sets that describe the hydrogeologic units, recharge, discharge, and conceptual model of the groundwater-flow system, and calculate hydraulic heads at discrete points and flow within the model domain. The program requires that the groundwaterflow system be subdivided, vertically and horizontally, into model cells. The hydraulic properties of the material in each cell are assumed to be homogeneous. The Bainbridge Island study area was subdivided by a horizontal grid of 139 columns and 197 rows; cells are a uniform $800 \mathrm{ft}$ per side (fig. 28). The large cell size and uniform grid spacing were selected to reflect the regional scale of this study. The extents of active cells on the Island in each layer are outlined in figures 29A-J. Although only Bainbridge Island is shown in the figures, the model was extended beyond Bainbridge Island so that any groundwater flow beneath Port Orchard could be determined. The area beyond the Island is not reported here because a more generalized hydrogeology based on a limited dataset was used to construct the model in those areas.

Vertically, the study area was subdivided into 33 layers having varying thicknesses. Thirty-two model layers (figs. 29A-J) were used to simulate the saturated unconsolidated sediments that overlie the bedrock, and one layer was used to simulate the upper bedrock. The Qva and QC1pi interbed aquifers were each represented by a single model layer (layer 2 and layer 4, respectively), and the QA1, QA2, and QA3 aquifers were each represented by eight model layers (layers 6-13 for QA1; layers 15-22 for QA2, and layers 24-31 for QA3). The aquifers are separated by confining units each represented by a single model layer (layers 1, 3, 5, 14, 23, and 32). Layer 33 was the bedrock layer. The QA1, QA2, and QA3 aquifers were subdivided into eight layers each to accurately simulate the position and dynamics of the saltwater/ freshwater interface using SEAWAT.

All model layers were necessarily simulated as confined units. This assumption means that the transmissivity and storativity remained constant for each layer for the duration of the simulation and model cells were not allowed to become inactive, even if the simulated water level decreased below the bottom of the layer. This simplification greatly improved the numerical stability of the model. Although model layer 1 was simulated as confined, it is in fact largely unconfined, and was therefore assigned storativity values between 0.1 and 0.5 that are representative of specific-yield values.

The MODFLOW-2000 and SEAWAT user interfaces require that all layers be present in all active cells in the model. In order to ensure proper model operation, where the hydrogeologic units constituting a model layer were absent, the layer was altered. A $0.5-\mathrm{ft}$ thickness was assigned to the model layer and the specified hydraulic properties were changed to represent hydraulic conductivities of an adjacent layer. This results in the simulated flow passing through the "altered" layer as if it were part of an adjacent model layer.

The top of layer 1 was created using LiDAR data (Puget Sound LiDAR Consortium, 2000) and bathymetry data (Finlayson, 2005). For each model cell, the top of layer 1 was calculated by resampling the land-surface altitude for all LiDAR or bathymetry grid cells that fell within that $800-\mathrm{ft}$ model cell. The elevation of the tops of the remaining model layers on the Island were determined relative to the surfaceelevation grid and depths of hydrogeologic unit contacts described in the hydrogeologic framework section of this report. The elevation of each unit was determined at a $100-\mathrm{ft}$ resolution and resampled up to the $800-\mathrm{ft}$ model cell size. The elevation of the top of the bedrock unit generally was unknown as no wells penetrate to bedrock north of the fault zone so the top of bedrock was assigned an elevation that was $100 \mathrm{ft}$ below the top of the QC4 layer in that region. The tops of the model layers for the Kitsap Peninsula area were based on a previous study of the SUBASE Bangor area (Kahle, 1998) where it overlapped with the study area and the areas outside of the SUBASE Bangor study area were interpolated using GIS to extend the layers to the remaining model domain. No detailed hydrogeologic framework was constructed for these areas.

\section{Time Discretization}

The model simulates transient conditions as SEAWAT does not have a true steady-state option. The transient simulation period (January 1995-December 2008) was divided into 168 monthly stress periods to represent temporal variations in recharge, discharge, and other groundwater-flow system processes. Each stress period consists of only one time step to coincide with the frequency of data collected in the field, because smaller time steps were not necessary for stable operation of the model. Initial conditions for the transient simulation period were developed from a 2,500year lead-in period that was used to simulate an approximate predevelopment steady-state condition for water levels and for the location of the saltwater/freshwater interface. 


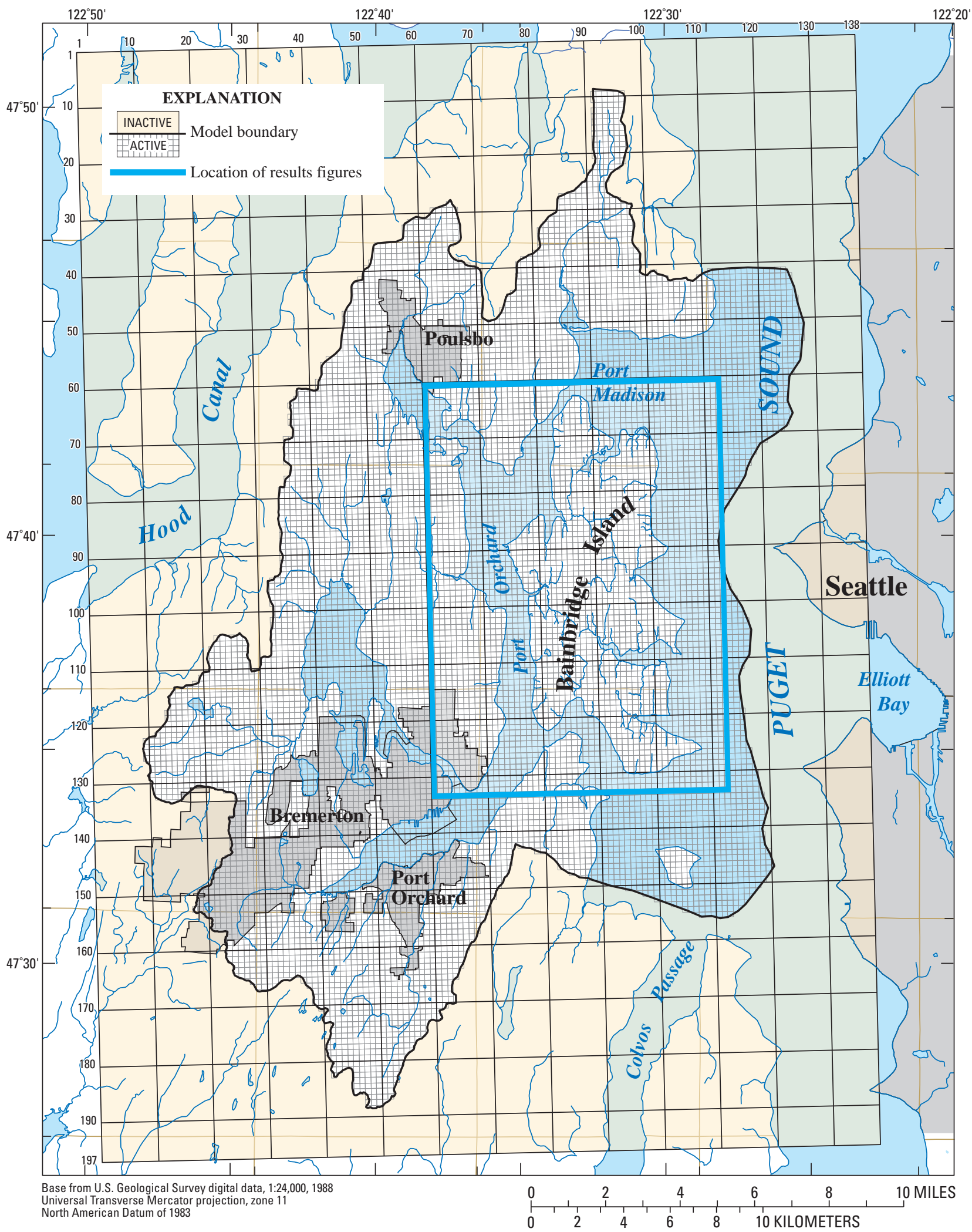

Figure 28. Location and extent of the groundwater-flow model for Bainbridge Island and vicinity, Washington. 


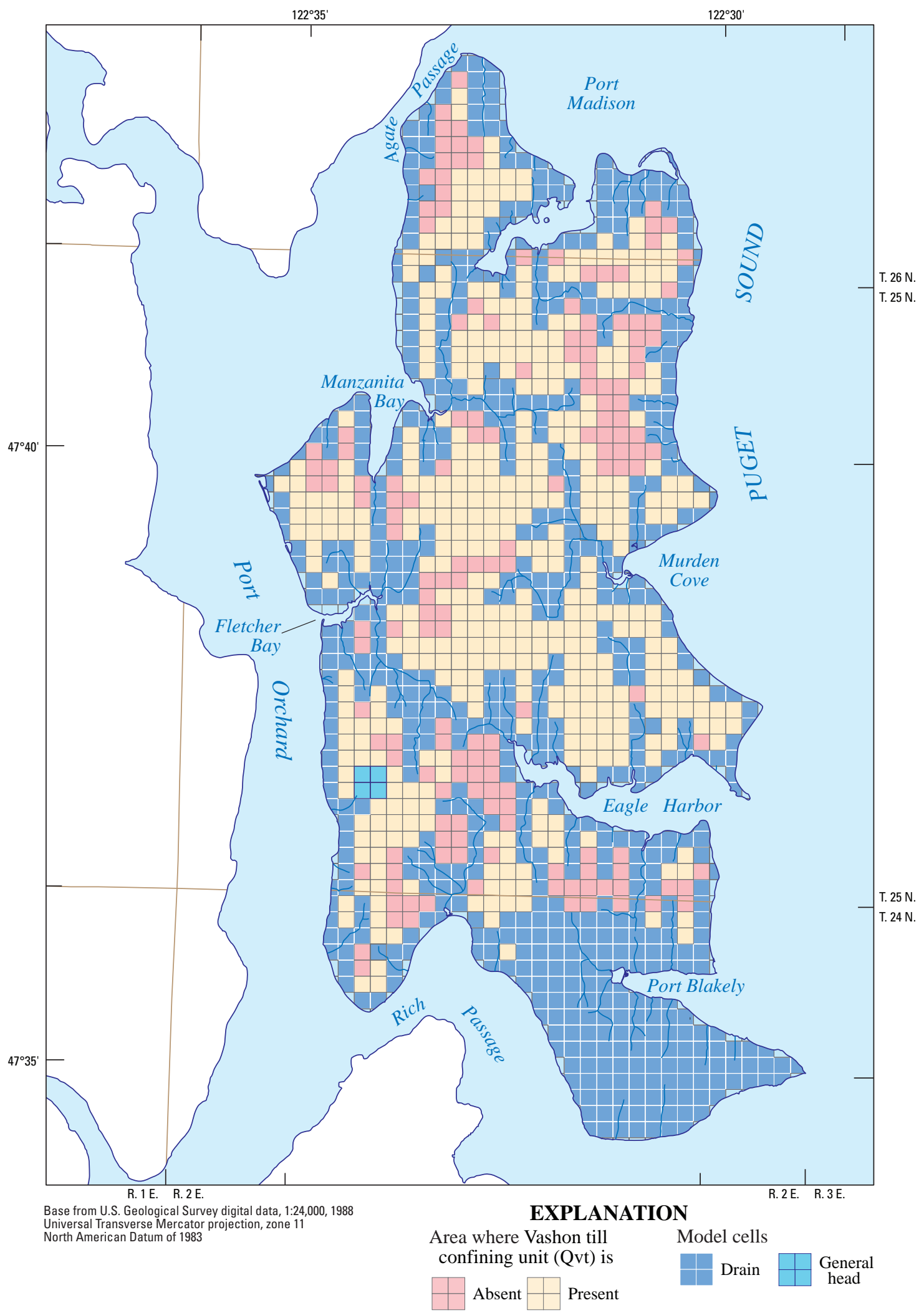

\section{A. Model layer 1 - Qvt confining unit (Qvt)}

Figure 29. Areal extent and location of drain and general-head cells for model layers for (A) model layer 1-Qvt confining unit (Qvt), $(B)$ model layer 2-Vashon advance aquifer (Qva), $(C)$ model layers 3 and 5 -upper confining unit $(Q C 1),(D)$ model layer 4-permeable interbeds (QC1 pi), (E) model layers 6 through 13-sea-level aquifer (OA1), ( $F$ ) model layer 14-middle confining unit (OC2), $(G)$ model layers 15 through 22-glaciomarine aquifer (OA2), ( $H$ ) model layer 23-lower confining unit (OC3), ( $/$ ) model layers 24 through 31-deep aquifer $(\mathrm{QA3})$, and $(J)$ model layer 32-basal confining unit (QC4), Bainbridge Island, Washington. 


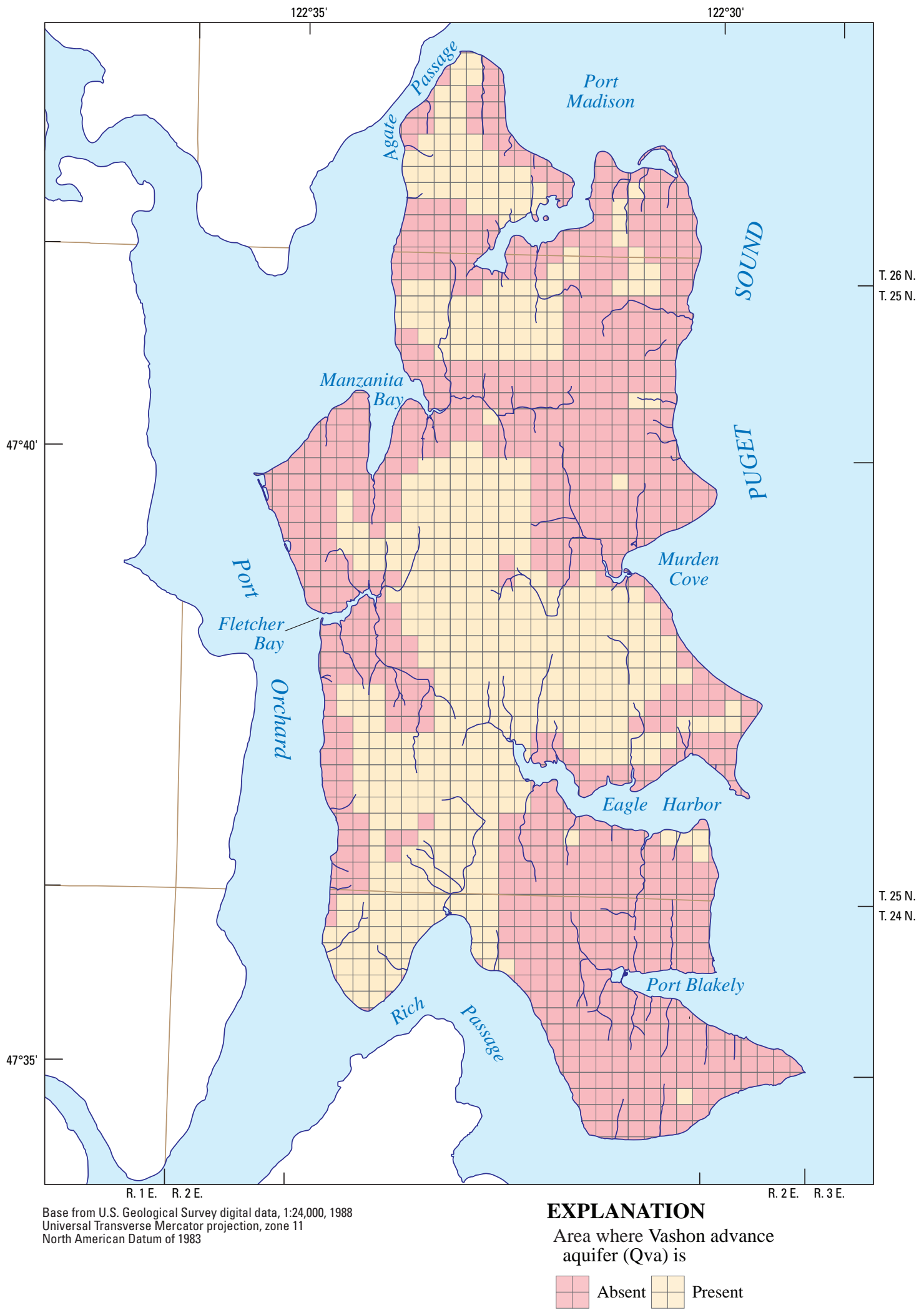

B. Model layer 2 - Vashon advance aquifer (Qva)

Figure 29.-Continued. 


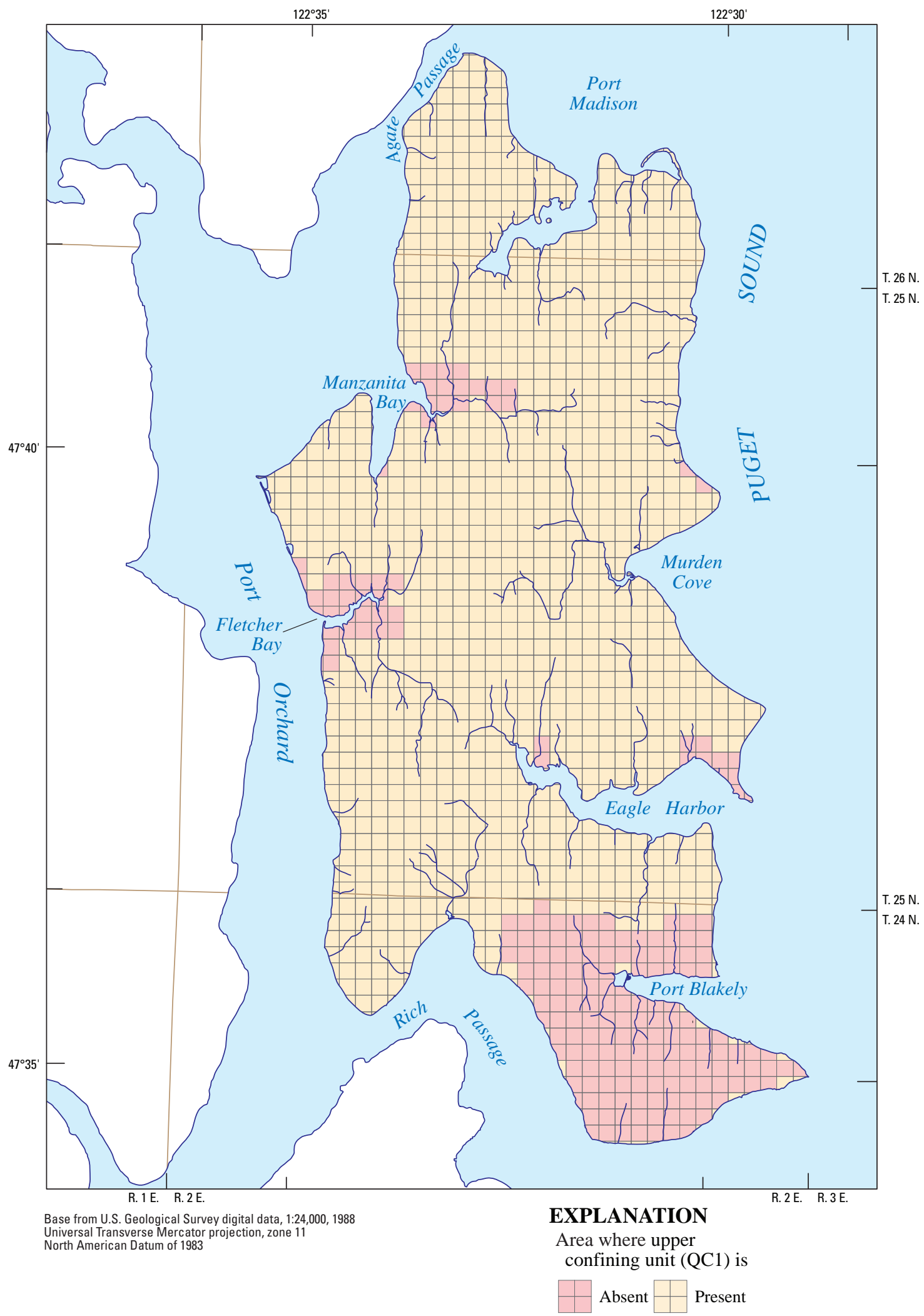

C. Model layers 3 and 5 - Upper confining unit (OC1)

Figure 29.-Continued. 


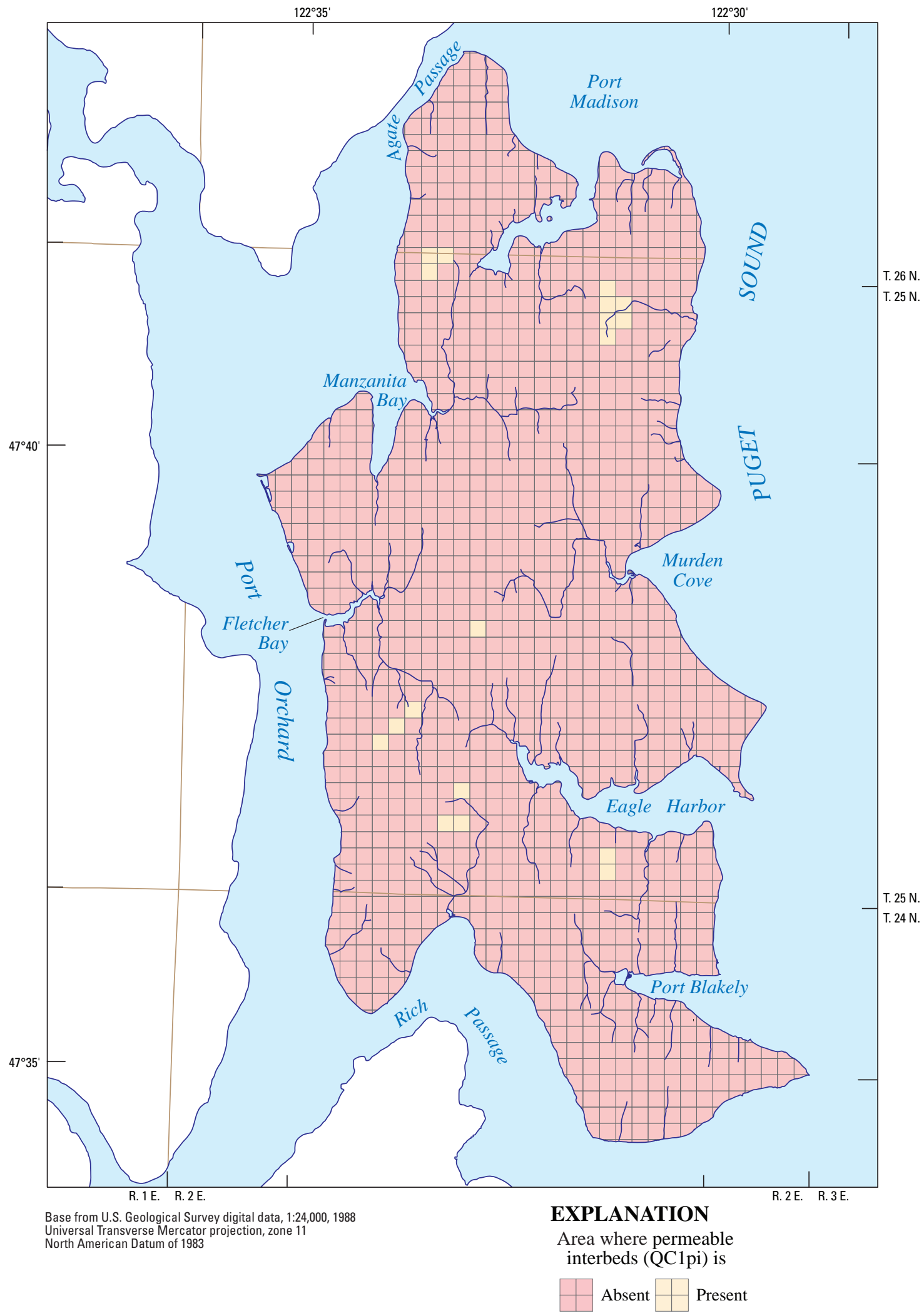

D. Model layer 4 - Permeable interbeds (QC1pi)

Figure 29.-Continued. 


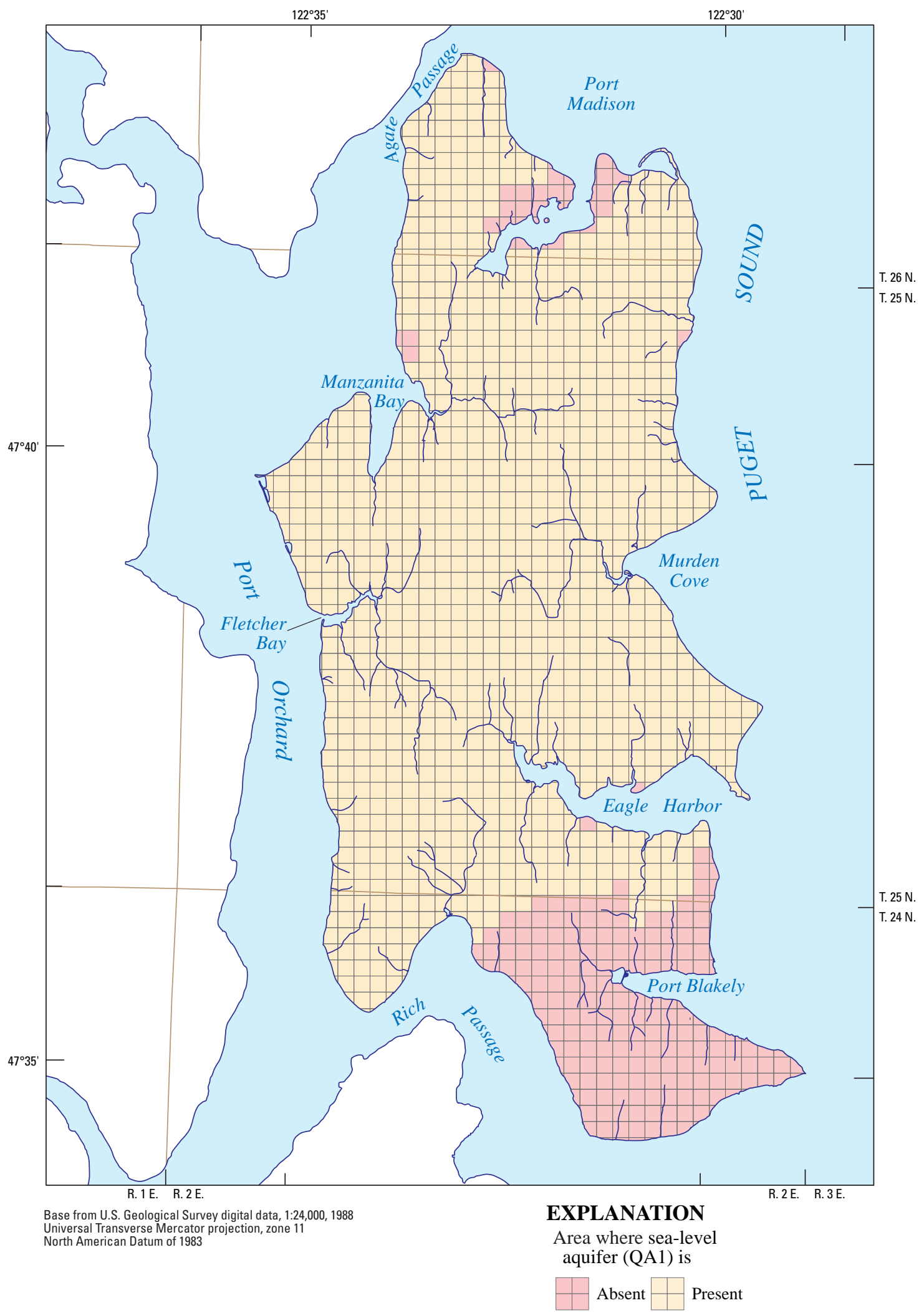

E. Model layers 6 through 13 - Sea-level aquifer (OA1)

Figure 29.-Continued. 


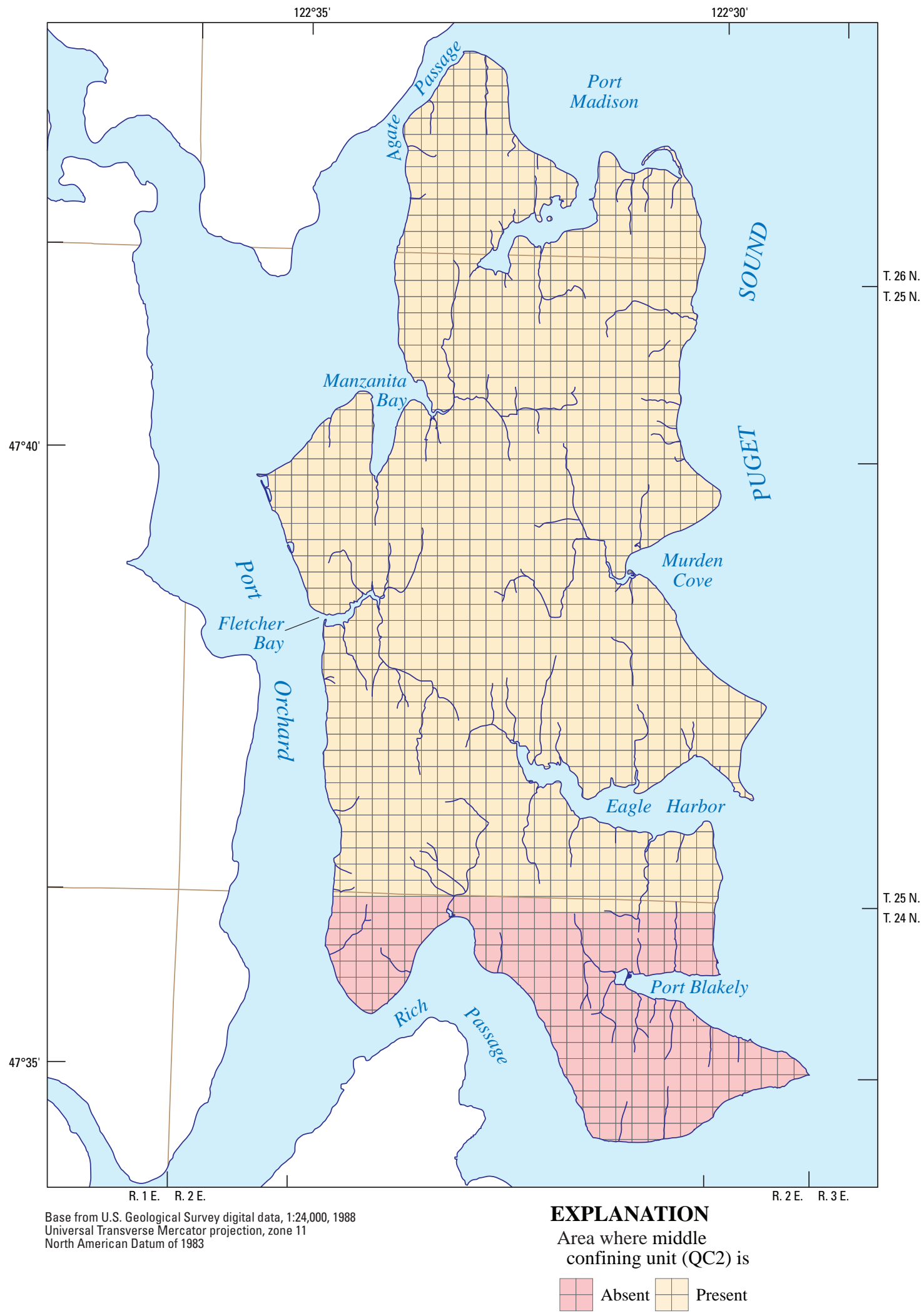

F. Model layer 14 - Middle confining unit (OC2)

Figure 29.-Continued. 


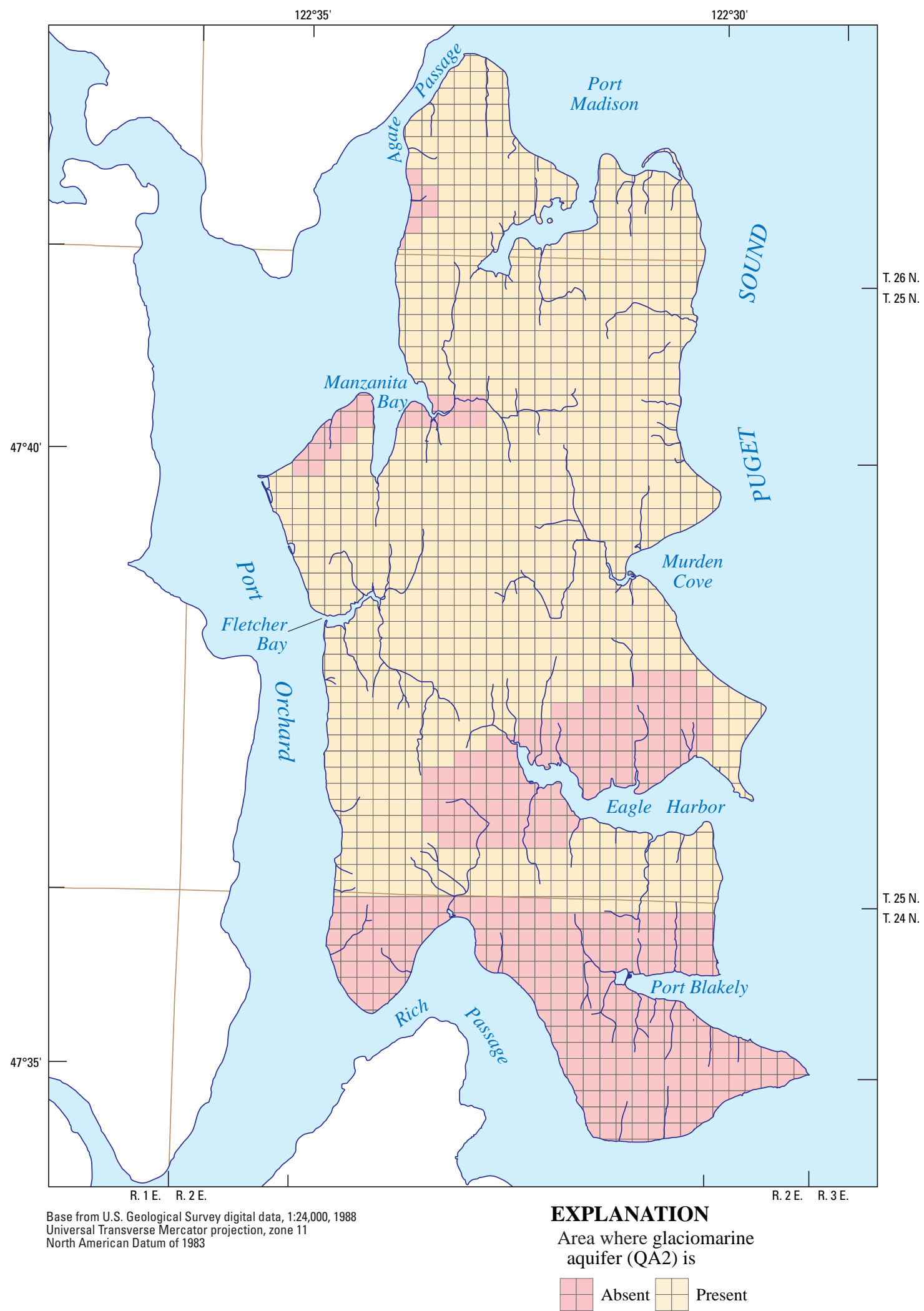

G. Model layers 15 through 22 - Glaciomarine aquifer (OA2)

Figure 29.-Continued. 


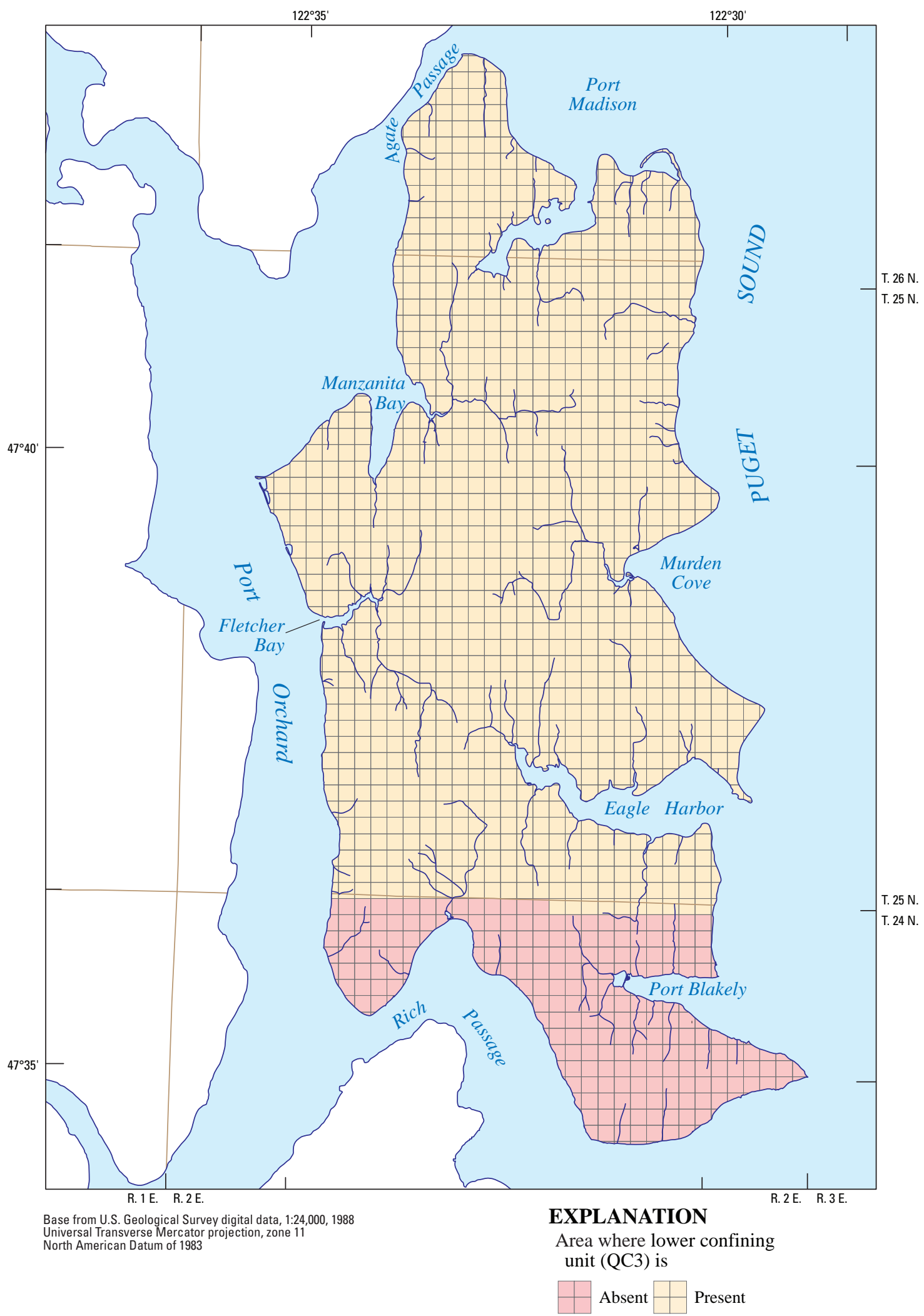

H. Model layer 23 - Lower confining unit (QC3)

Figure 29.-Continued. 


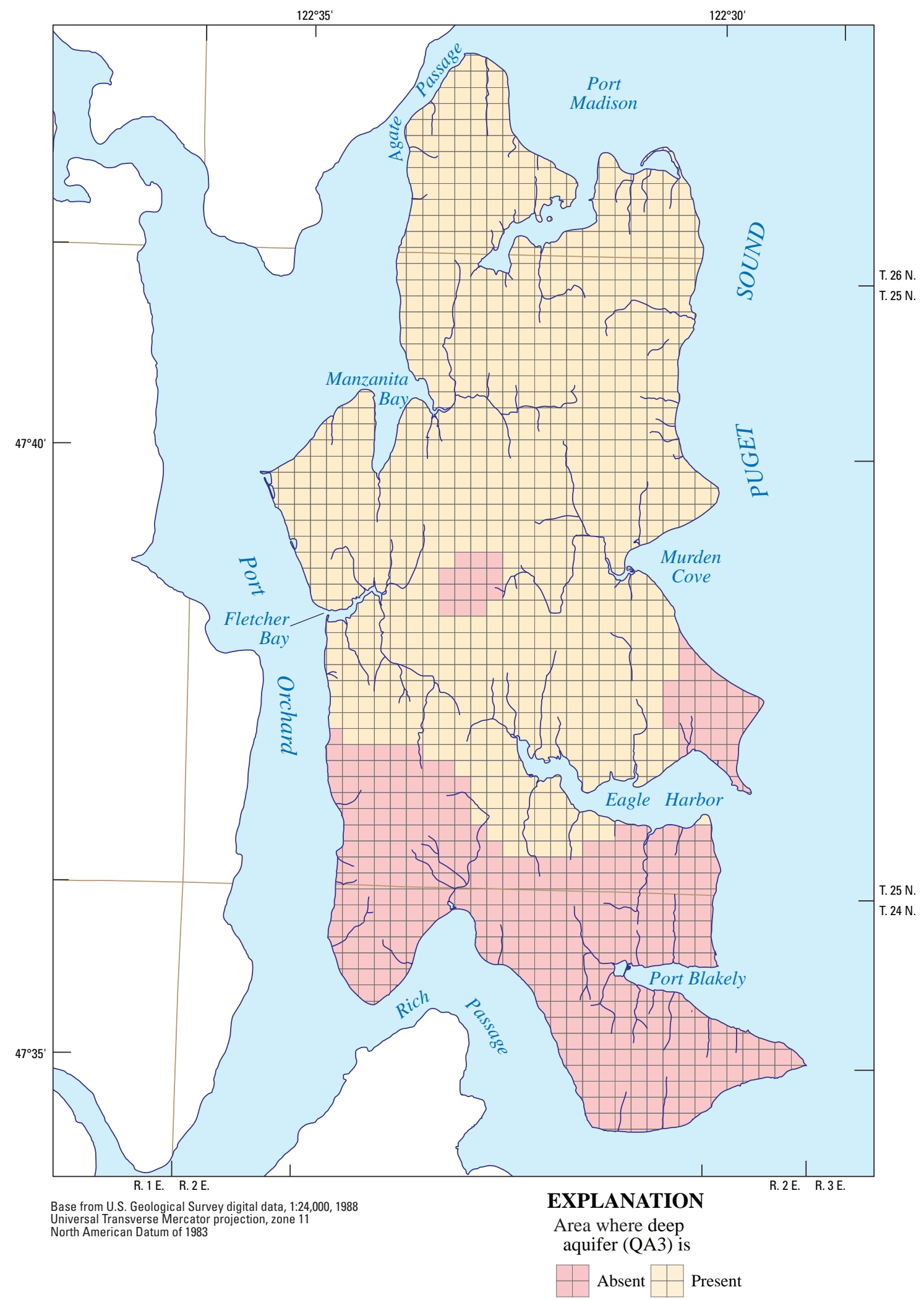

I. Model layers 24 through 31 - Deep aquifer (QA3)

Figure 29.-Continued. 


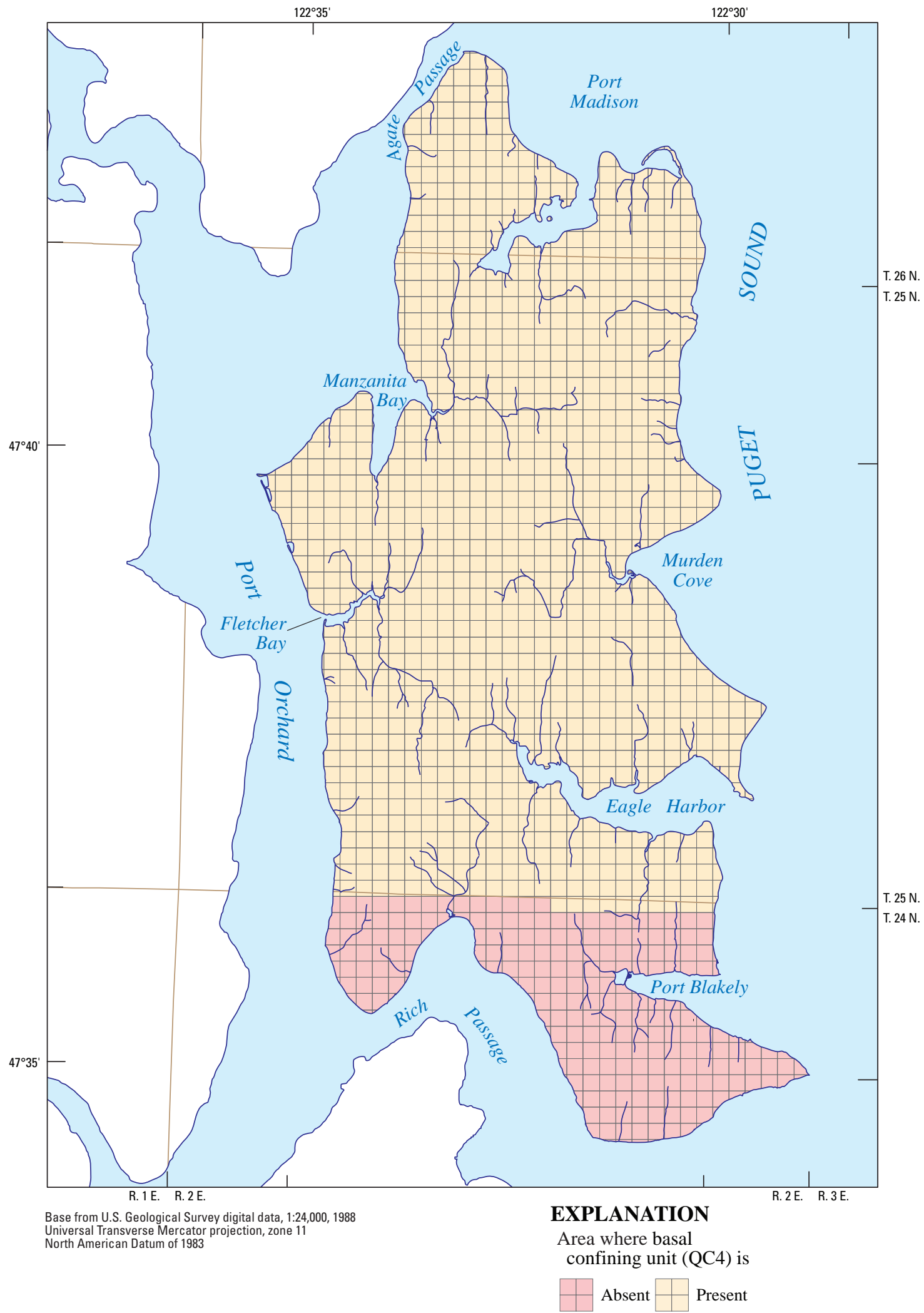

J. Model layer 32 - Basal confining unit (OC4)

Figure 29.-Continued. 


\section{Boundary Conditions}

Boundary conditions in a groundwater-flow model define the locations and manner in which water enters and exits the active model domain. The general conceptual model for the Bainbridge Island model is that water enters the system as recharge from precipitation and septic-system returns to the water table and exits the system as groundwater pumpage, streamflow, and groundwater discharge to Puget Sound. Three types of boundaries were used in the model: no flow (outer model boundary), head-dependent flux (constant head, general head, and drains), and specified flux (recharge and pumping wells). The boundaries of the model coincide as much as possible with natural topographic, geologic, and hydrologic boundaries (fig. 28).

The areal boundaries of the model are either no-flow or head-dependent flux boundaries. All areal boundaries on land are at the major topographic divide along the Kitsap Peninsula (fig. 28). The model was extended to the topographic divide, rather than modeling just the Island, so that any possible groundwater flow beneath Port Orchard could be determined. The topographic divide generally defines the lateral model boundaries on the northern, western, and southern boundaries (fig. 28). These natural features act as no-flow boundaries as they are considered coincident with groundwater divides. The entire outer model boundary is simulated as a no-flow boundary, with the exception of the eastern boundary of the model in Puget Sound. The no-flow boundaries are far from Bainbridge Island so they do not affect the simulation results of the Island, even if effects of localized groundwater pumping on the Kitsap Peninsula encroach on these boundaries. All areal boundaries offshore in layers 2-33 are head-dependentflux boundaries, and were simulated with the general-headboundary (GHB) module of MODFLOW (McDonald and Harbaugh, 1988). Water exits the system at this location through submarine groundwater flow. The eastern boundary of the model is at the lowest point of Puget Sound, approximately half way between Bainbridge Island and Seattle. Cells in direct contact with saltwater in layer 1 were modeled as constanthead cells with a salinity value of 33 grams per liter. The head specified in these cells was zero to represent the surface of Puget Sound.

Layer 1 (fig. 29A) of the model includes specified-flux and head-dependent-flux boundary cells. The specified-flux boundary is areally applied groundwater recharge, and the head-dependent boundaries represent streams, springs, or groundwater seeps. Recharge was simulated with the recharge (RCH) module (McDonald and Harbaugh, 1988) and is discussed in more detail in the Model Recharge section. Streams, springs, and groundwater seeps were simulated with the drain (DRN) module (McDonald and Harbaugh, 1988) and are discussed in the Streams and Lakes section. The bottom boundary of the model is a no-flow boundary (bottom of layer 33).

\section{Streams and Lakes}

Many small streams are present in the study area and were simulated using the DRN package (fig. 29A). The DRN package was selected to represent streams because the streams in the study area are groundwater fed and dry up in the summer if the water table declines below the altitude of the streambed. The DRN package allows water to flow from the groundwater system to the streams if the simulated water level in the model cell is greater than the specified altitude of the stream in the drain cell. The altitude of the drain cell was set equal to the altitude of the centroid of the stream segment present within a given model cell. Drains were placed along the shorelines of the model to simulate springs and groundwater seeps that occur throughout the area in bluffs along the coast. The altitude of these drain cells was set to the land-surface. Drains also were placed in areas where bedrock outcrops at the surface to simulate the routing of recharge in those areas of low hydraulic conductivity to nearby streams. The altitude of these drain cells was set to the land-surface altitude.

The GHB package of MODFLOW was used to simulate subsurface discharge from the lakes to the underlying aquifers. Representation of the lake in this way allows flow into and out of a cell in proportion to the difference between the head in the cell and the specified head of the lake. The specified lake stages were determined from USGS 1:24,000-scale topographic maps. The lake-bottom conductance is a function of the surrounding hydrogeologic material and the lake area. The only lake modeled on the Island was Gazzam Lake (figs. 1 and $\underline{29 A}$ ).

\section{Model Recharge}

The recharge package of MODFLOW was used to simulate groundwater recharge from precipitation, and return flows from septic systems. Recharge (in units of feet per day) is applied as a specified flux to the uppermost active cell throughout each monthly stress period. Precipitation is the dominant source of water recharging the groundwater system in the study area, and variations in recharge are related to spatial and temporal variations in precipitation, the permeability of surficial hydrogeologic units, and land-cover characteristics. The distribution of recharge from precipitation in the study area was estimated for the Island using the previously described precipitation-recharge regression equations developed using the DPM, and was estimated for the Kitsap Peninsula using the regression equations of Bidlake and Payne (2001). Both estimates were derived using annual precipitation from the PRISM climate group (accessed September 2009 at http://prism.oregonstate.edu), and monthly recharge amounts were estimated from annual estimates using the monthly fractional drainage from the root zone from Bidlake and Payne (2001). 
Secondary recharge to the area from septic-system returns was estimated as previously described in this report. These returns were applied to each corresponding model cell in layer 1.

\section{Groundwater Withdrawals}

The well package of MODFLOW (McDonald and Harbaugh, 1988) was used to simulate groundwater withdrawals from pumping wells. The well package simulates a specified-flux boundary in each model cell to which a well is assigned based on the withdrawal rate for each well or group of pumping wells in the cell. Withdrawals (in units of cubic feet per day) were specified for each monthly stress period. The vertical distribution of withdrawal among model layers was based on the reported depth of the open interval of the well and the hydrogeologic framework. Pumping wells also were included for the Kitsap Peninsula area. Actual monthly pumping totals were obtained from the largest public-supply systems on the peninsula, and domestic-pumping amounts were estimated using the DOE well database and by assuming the same domestic-well pumping rate as for the Island's domestic wells.

\section{Model Calibration}

The transient groundwater model has 168 monthly stress periods that begin in 1995 and extend through 2008 and was calibrated to the time period beginning in 2006 and extending through 2008. This time period corresponds to most of the monthly water-level measurements that were available for the Island. Additionally, monthly water levels on the Kitsap Peninsula were included in the calibration process if they were from wells that penetrated the QA2 and QA3 aquifers. Parameters selected for estimation during model calibration were (1) aquifer and confining-unit horizontal hydraulic conductivity, (2) aquifer and confining-unit vertical hydraulic conductivity, and (3) aquifer and confining-unit specific storage. Groundwater-pumping rates and recharge values were considered reliable and were not adjusted during calibration.

The model was calibrated using an inverse modeling technique, parameter-estimation, which uses regularized inversion (Doherty, 2003; 2005) and employs pilot points for spatial hydraulic-property estimation. This approach allowed a relatively large number of parameters $(1,110)$ to be estimated for many of the model inputs including horizontal and vertical hydraulic conductivities and specific storage. Use of pilot points is a method of spatial parameterization for model inputs, which, in this case, was the various hydraulic properties used in the groundwater-flow model. These hydraulic properties are assigned to sets of pilot points distributed throughout the model domain rather than directly to the grid elements of the model (Doherty, 2003, 2005).
Hydraulic properties of the model are then estimated through spatial interpolation using kriging from the pilot points to the model grid. The result is a smooth variation of the hydraulic property over the model domain. A number of studies have used pilot points for groundwater model calibration (de Marsily and others, 1984; LaVenue and Pickens, 1992; Petkewich and Campbell, 2007) and they have been proven to be a powerful and flexible way to attempt to represent spatial heterogeneity in various types of aquifer-hydraulic properties.

Pilot points generally were concentrated on Bainbridge Island and in Puget Sound immediately surrounding the Island with a few scattered points on the Kitsap Peninsula (fig. 30). The pilot points were distributed vertically so that each hydrogeologic unit contained pilot points. If a pilot point for any given hydrogeologic unit fell in a location where that unit was absent, it was deleted from that location for that unit to ensure that the pilot points for each hydrogeologic unit were kriged only to other points within that unit.

The goal of inverse modeling is to minimize the objective function, which is the weighted sum-of-squares differences between model-generated observation values and those measured in the field (Doherty, 2005). Observations were weighted differently to reflect their importance in determining the optimization outcome. For example, groundwater levels measured on the Island were weighted higher than groundwater levels measured on the peninsula to reflect their greater importance in the calibration process and the results.

Groundwater conditions were calibrated using 2,682 water-level measurements. The calibration included 705 water levels from the Qva aquifer system, 127 from the QC1pi aquifer, 1,184 from the QA1 aquifer, 341 from the QA2 aquifer, and 292 from the QA3 aquifer. The residuals, or the differences between the measured and simulated groundwater levels, were distributed normally for all aquifers and had a maximum range from $-81 \mathrm{ft}$ in the QA1 aquifer to $102 \mathrm{ft}$ in the QC1pi aquifer, with mean residuals of -2.8, 46.8, -5.2, 4.1, and $0.7 \mathrm{ft}$ for the Qva, QC1pi, QA1, QA2, and QA3 hydrogeologic units, respectively (table 6). The percent of simulated values within the 20-ft calibration target varied between 16.5 and 100 percent for the individual aquifers, with the simulated QC1pi aquifer water levels having the poorest fit and the QA2 aquifer the best fit, respectively.

Another method of evaluating the fit of calibration is to divide the standard deviation of model residuals by the overall range of water-level observations for a particular aquifer. The lower the ratio the better, with ratios less than 0.10 representing a good model fit (Kuniansky and others, 2004). Calculated ratios of 0.10 or less indicate that residuals are less than 10 percent of the altitude range of the observations. The fit of calibration was equal to 0.214 for the QC1pi aquifer and 0.157 for the QA3 aquifer and less than 0.10 for the other three aquifers (table 6). The poorer fit for the QC1pi aquifer likely is due to the limited number of observations for this model layer and the isolated nature of the pockets of permeable materials that make up this unit. 


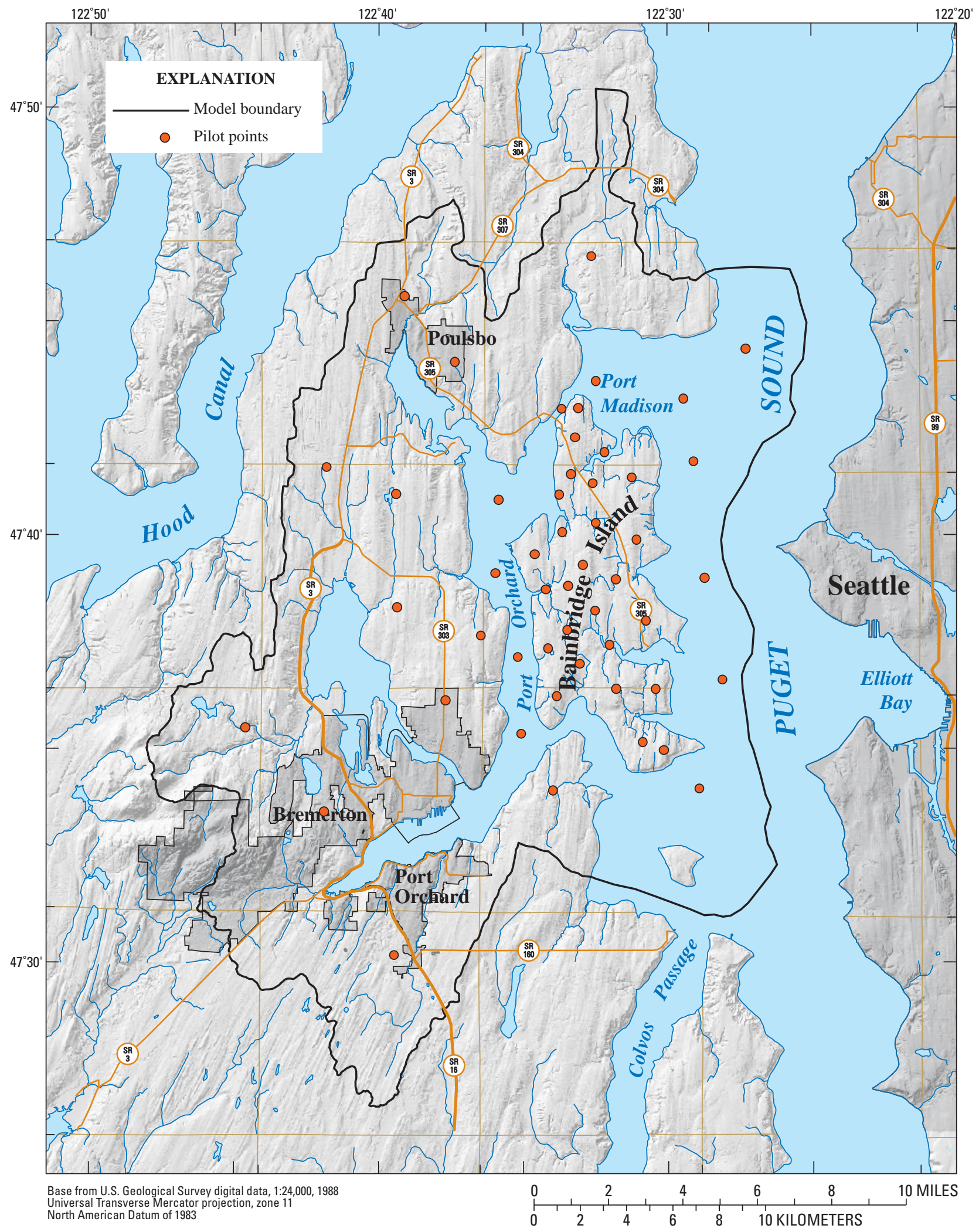

Figure 30. Horizontal distribution of pilot points used to calibrate the model domain, Bainbridge Island and vicinity, Washington. 
Determining whether a calibrated model indicates any bias can be accomplished by plotting the observed values compared with the simulated values (fig. 31). The values should plot close to the 1:1 line. The observed and simulated water levels shown in figure 31 generally plot along the 1:1 line. The higher observed values plotted somewhat beneath the 1:1 line mainly due to the poor simulation of values in the QC1pi unit.
Table 6. Calibration statistics for numerical flow model of Bainbridge Island and surrounding areas, Kitsap County, Washington.

\begin{tabular}{lccccc}
\hline \multicolumn{1}{c}{ Calibration parameter } & Qva & QC1pi & OA1 & QA2 & OA3 \\
\hline Number of observations & 705 & 127 & 1,184 & 341 & 292 \\
Minimum residual, in feet & -64 & -37 & -81 & -24 & -32 \\
Maximum residual, in feet & 41 & 102 & 85 & 36 & 27 \\
Mean residual, in feet & -2.8 & 46.8 & -5.2 & 4.1 & 0.7 \\
Percent of simulated values within \pm 20 feet & 78 & 16.5 & 80.8 & 100 & 98.3 \\
Standard deviation of residuals & 19 & 44 & 20.2 & 13 & 7.7 \\
Water-level range, in feet & 278.4 & 205.1 & 230.5 & 132.4 & 48.7 \\
Calibration fit & 0.068 & 0.214 & 0.088 & 0.098 & 0.157 \\
\hline
\end{tabular}

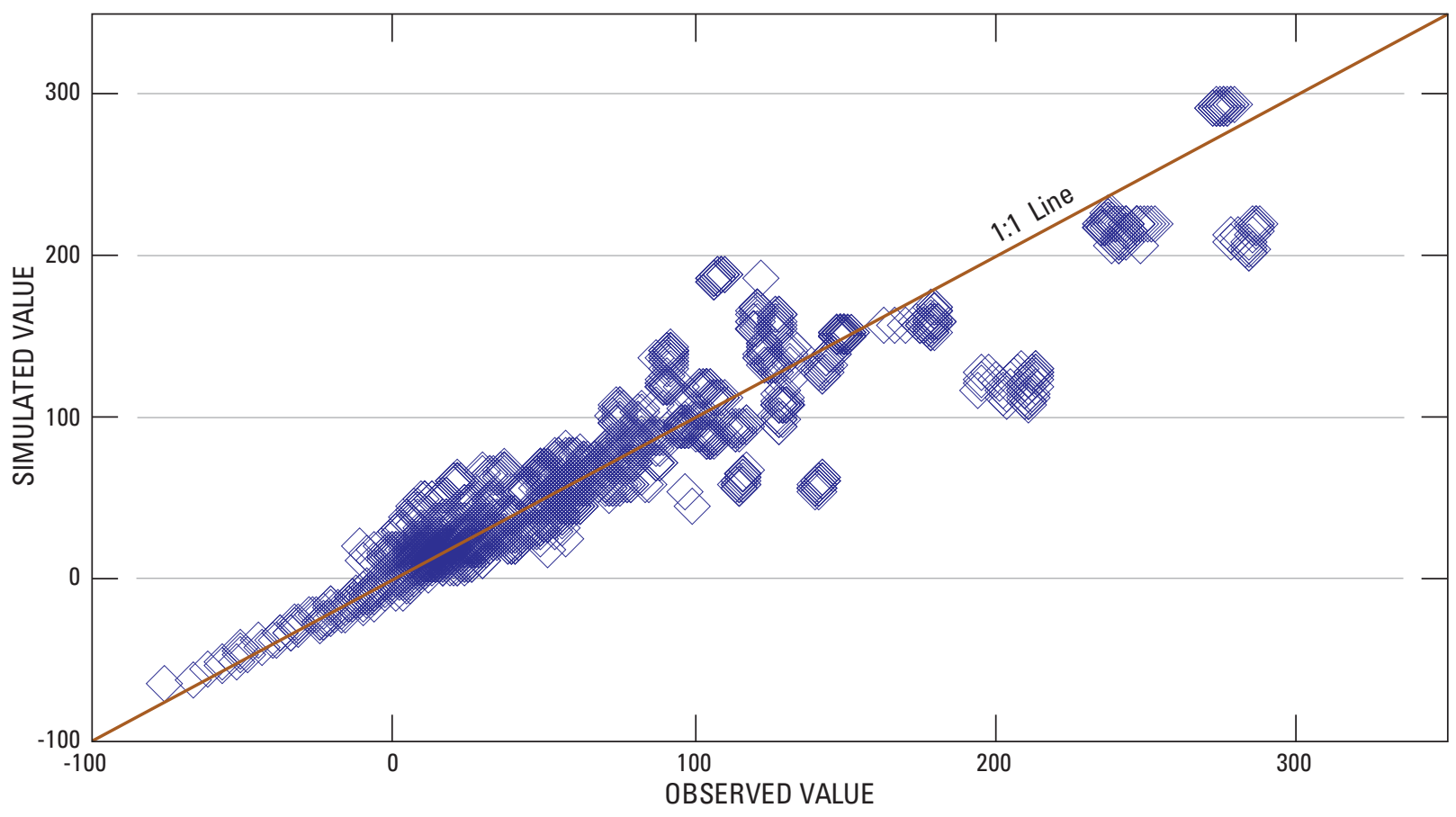

Figure 31. Simulated and observed hydraulic-head values in the groundwater-flow model of Bainbridge Island and vicinity, Washington. 


\section{Comparison of Simulated and Measured Hydraulic Heads}

A comparison of simulated and measured hydraulic heads indicates that the model reasonably simulates the measured magnitudes and general groundwater-head patterns (figs. 32A$\underline{E}$ ). The residuals are calculated by subtracting the simulated heads from the measured heads, so positive residuals are at sites where the model predicts heads that are lower than measured (under prediction), and negative residuals are at sites where the model predicts heads that are higher than measured (over prediction). The smaller the residuals, the better the model is at predicting the water levels. The spatial distribution of the hydraulic-head residuals does not indicate any major patterns of bias with the exception of the QC1pi unit where the model tends to under predict the hydraulic heads.

For the Qva aquifer, the average residuals were almost entirely within $20 \mathrm{ft}$ (fig. 32A). The model tends to slightly over predict the hydraulic heads at the head of Fletcher Bay, but the remainder of the Island does not indicate any overall bias. The model accurately predicts the same general flow pattern as was mapped in figure 18.

The QA1 aquifer had a few locations where the average residual was greater than $40 \mathrm{ft}$ and two locations where the residuals were greater than $60 \mathrm{ft}$ (fig. 32C). The distribution of positive and negative residuals indicates no overall bias in this aquifer and the directions of flow predicted by the model generally match those mapped in figure 20.

The average residuals in the QA2 aquifer were all within $20 \mathrm{ft}$ indicating a good match with observed head values (fig. 32D). Although general flow patterns were not distinguishable based on the observation-well data alone (fig. 21), the model indicates that the QA2 aquifer has a radial flow pattern similar in shape to the QA1 aquifer with higher heads in the interior of the Island and with downward flow from QA1 to QA2.

The average residuals for the QA3 aquifer were all within $20 \mathrm{ft}$ also indicating a good match with the observed head values with no spatial pattern of bias (fig. 32E). As with the QA2 aquifer, general flow patterns were not distinguishable based on the observation-well data (fig. 22); however, the model indicates that flow occurs radially off the Island in the southern part of the aquifer with submarine discharge to Puget Sound in the west and east and that water flows from the Kitsap peninsula to the Island and then discharges to Puget Sound in the east on the northern end of the Island. No saltwater intrusion was evident under the 2008 conditions with the saltwater/freshwater interface remaining offshore. Sufficient recharge to push saltwater offshore is present in all aquifers.

\section{Sensitivity Analysis and Final Parameter Values}

The ability to estimate a parameter value during the calibration process is related to the sensitivity of the simulated model output to changes in the parameter value. For example, if a parameter has a high sensitivity, observation data exist to effectively estimate the value. Changing the value of parameters with low sensitivity has little effect on the modelcalibration process. Insensitive parameters may or may not be close to their corresponding field values and are not likely to be estimated accurately during the parameter-estimation process.

Relative composite sensitivities are a measure of composite changes in model outputs that are caused by small changes in the value of a modeled parameter (Doherty, 2005). For a given modeled parameter, the larger the value of the associated relative composite sensitivity the more sensitive the model is to that parameter. Relative composite sensitivities were calculated and analyzed for 1,110 parameters used in the model-calibration process (table 7). Median sensitivities are presented for each hydrogeologic unit for the horizontal and vertical hydraulic conductivities and the storage coefficients.

Overall, the model is most sensitive to the horizontal hydraulic-conductivity pilot points for the QA1, Qva, and Qvt units, and the vertical hydraulic-conductivity pilot points in the QC1 unit. The model generally was insensitive to the storage-coefficient pilot points, the horizontal hydraulicconductivity pilot points in the confining units, the vertical hydraulic-conductivity pilot points in the aquifer units, and all parameters in the bedrock unit. These results were as expected with the aquifers being most sensitive to changes in horizontal hydraulic conductivity and the confining units being most sensitive to the vertical hydraulic conductivity.

The final parameter values for the 1,110 pilot points are shown in table 7. The highest median value for estimated horizontal hydraulic conductivity was in the Qva aquifer (44.24 ft/d) followed by the QA3 aquifer (13.44 ft/d). The QA2 aquifer had the lowest median value for the estimated horizontal hydraulic conductivity at $0.34 \mathrm{ft} / \mathrm{d}$. These values were within the range of values estimated using the specificcapacity data (table 4). The median vertical hydraulic conductivities generally were an order of magnitude smaller than the horizontal hydraulic conductivities and ranged from $0.128 \mathrm{ft} / \mathrm{d}$ for the Qva aquifer to $5 \times 10^{-6} \mathrm{ft} / \mathrm{d}$ for bedrock. The median storage coefficients ranged from 0.162 for the Qvt layer to $2.9 \times 10^{-6}$ for the QA3 aquifer. 


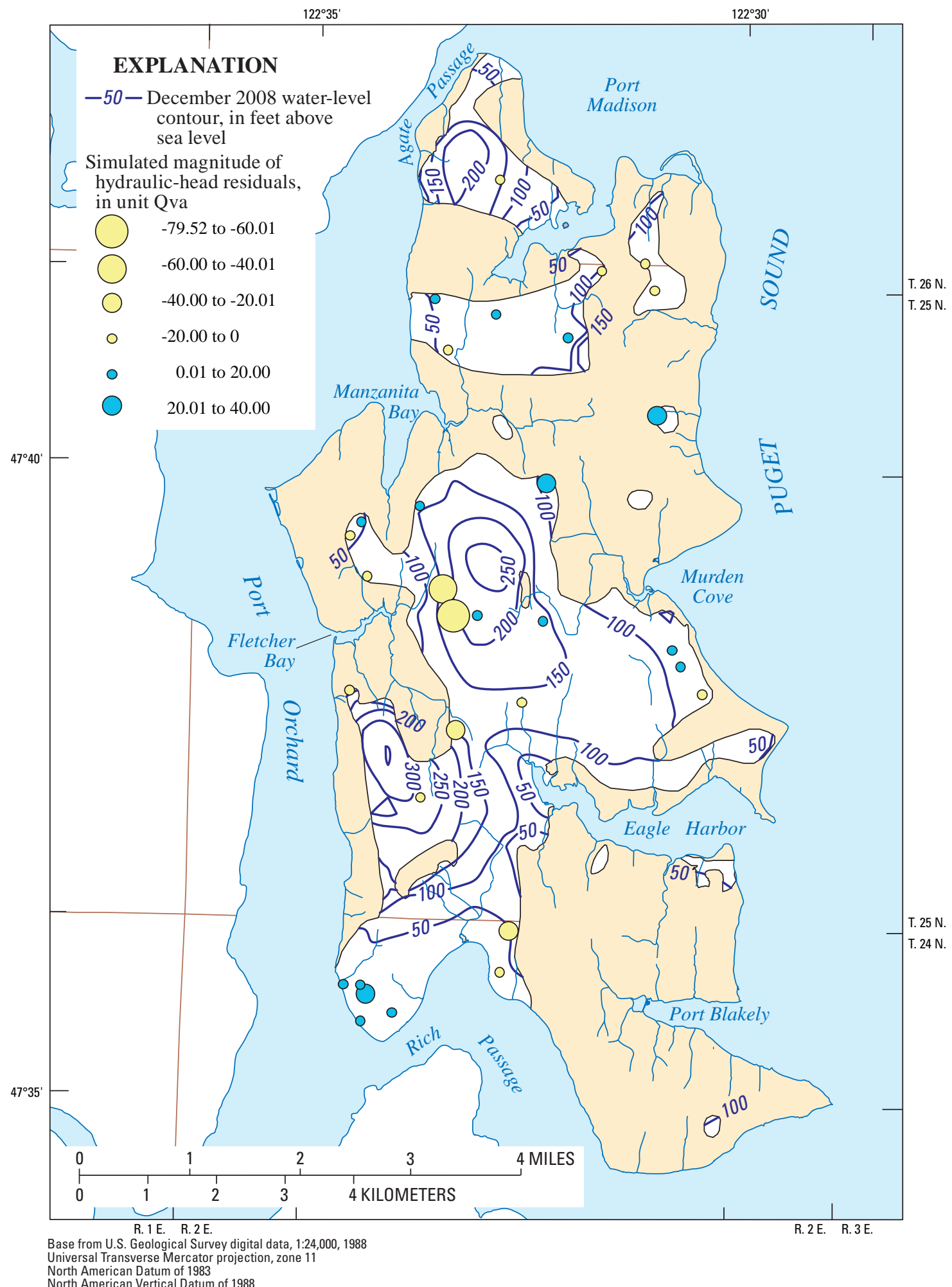

A. Model layer 2 - Vashon advance aquifer (Ova)

Figure 32. Location and simulated magnitude of hydraulic-head residuals in $(A)$ model layer 2Vashon advance aquifer (Qva), (B) model layer 4-permeable interbeds (OC1pi), $(C)$ model layers 6 through 13-sea-level aquifer $(\mathrm{QA} 1),(D)$ model layers 15 through 22-glaciomarine aquifer (QA2), and $(E)$ model layers 24 through 31 - deep aquifer (QA3), Bainbridge Island, Washington. 


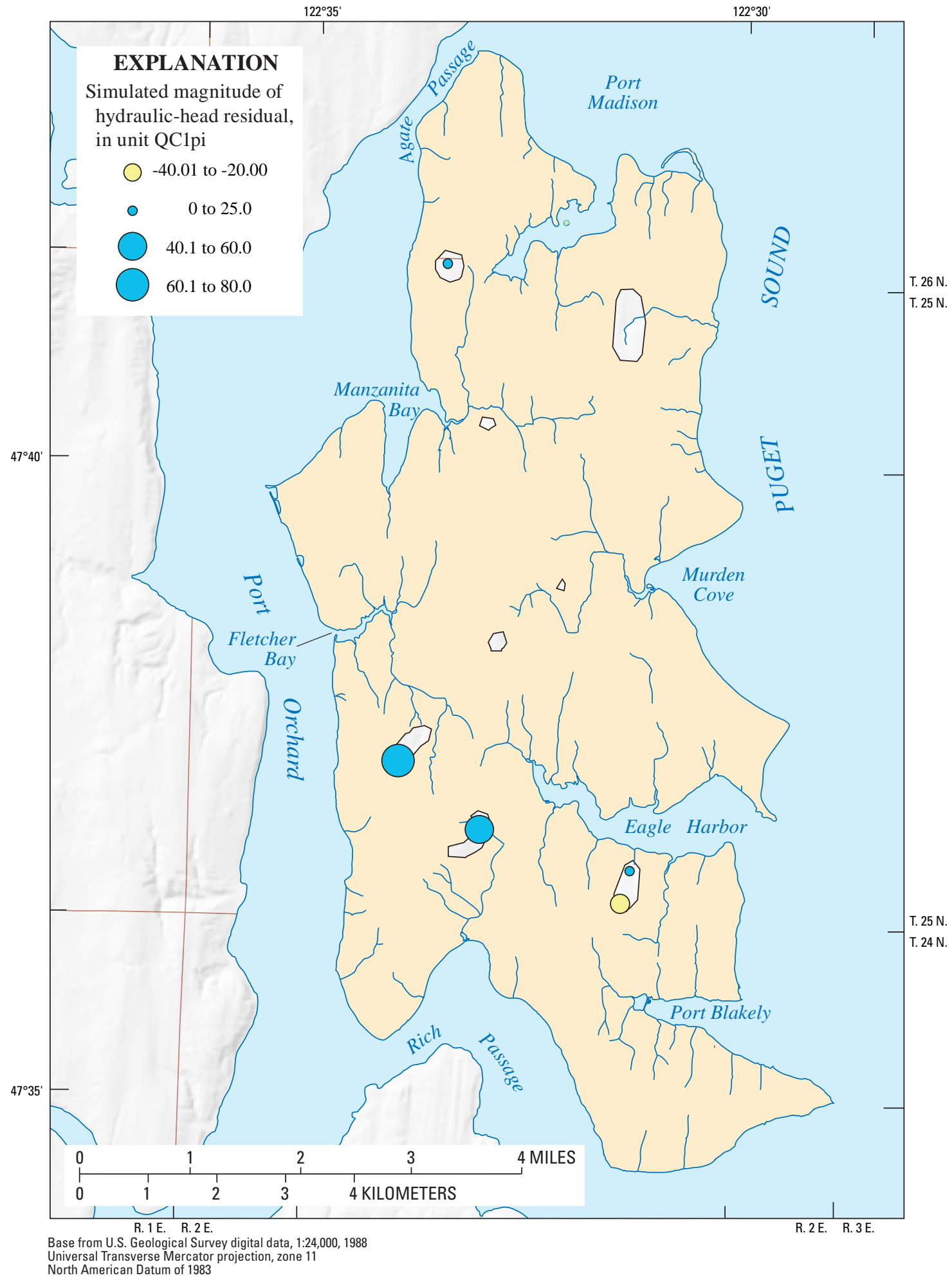

B. Model layer 4 - Permeable interbeds (OC1pi)

Figure 32.-Continued. 


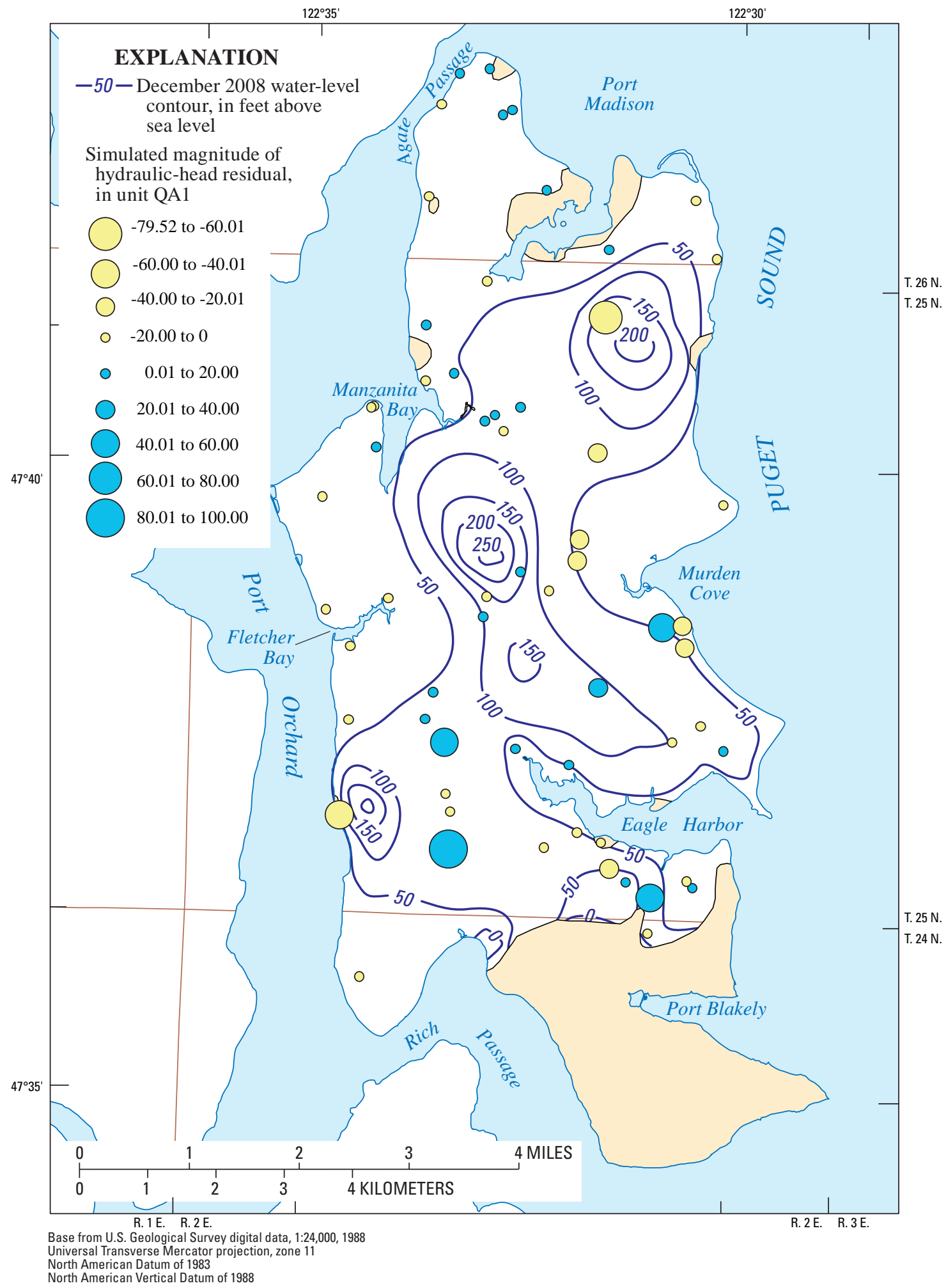

C. Model layers 6 through $13-$ Sea-level aquifer (OA1)

Figure 32.-Continued. 


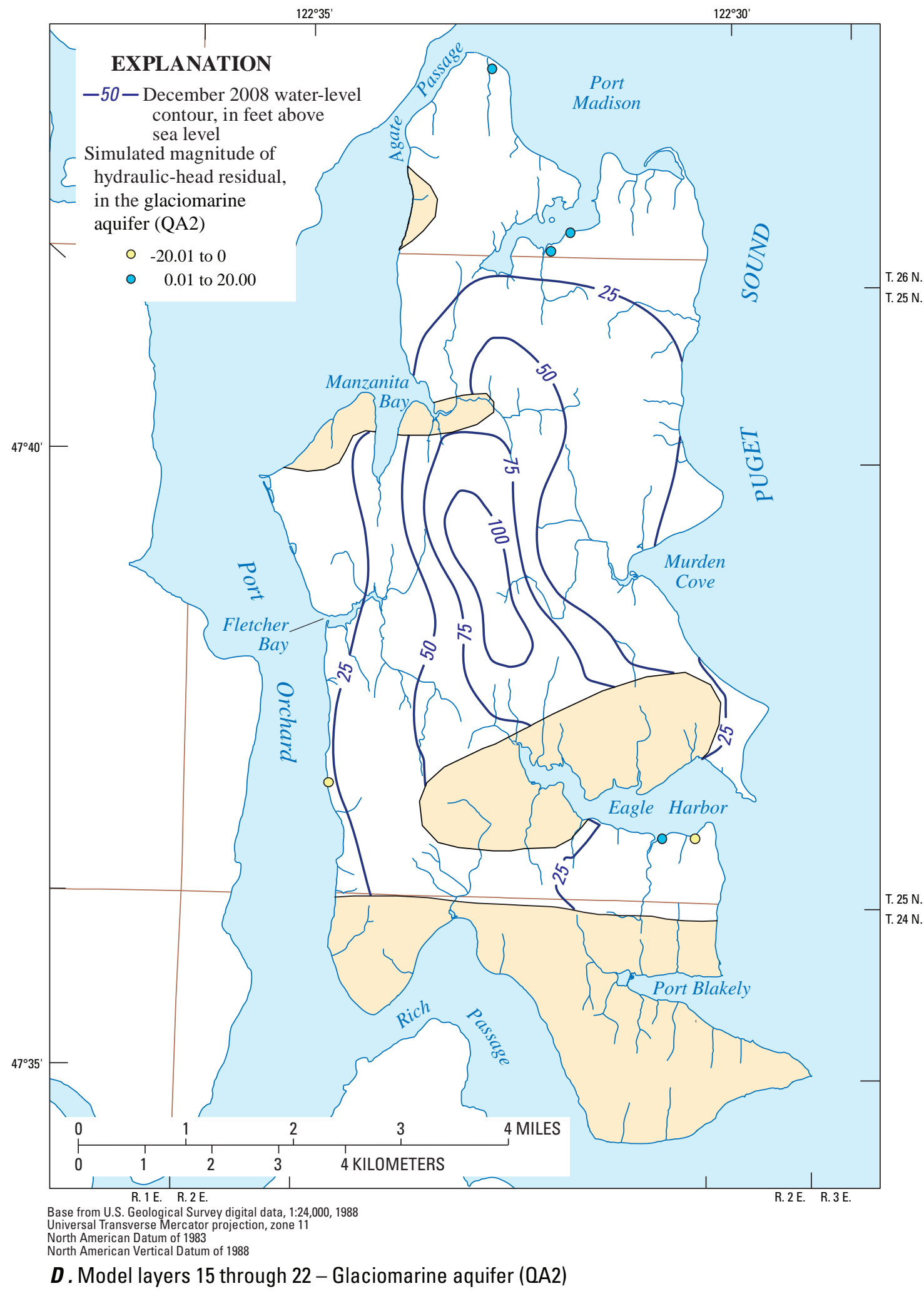

Figure 32.-Continued. 


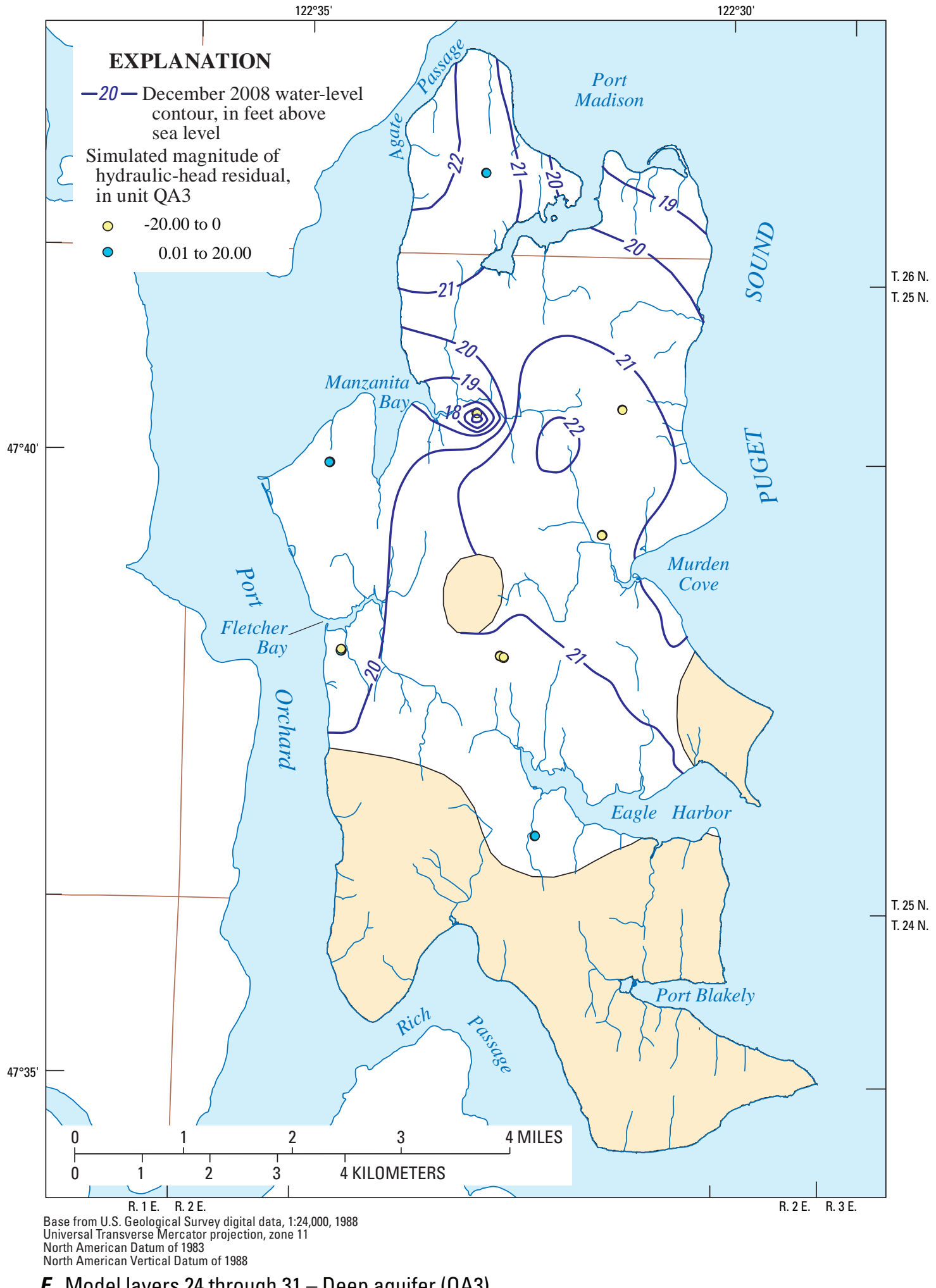

E. Model layers 24 through 31 - Deep aquifer (OA3)

Figure 32.-Continued. 
Table 7. Summary of parameter sensitivities and final values for 1,110 pilot points, Bainbridge Island, Washington.

\begin{tabular}{|c|c|c|c|c|c|c|}
\hline \multirow{2}{*}{$\begin{array}{c}\text { Parameter } \\
\text { name }\end{array}$} & \multirow{2}{*}{ Description } & \multirow{2}{*}{$\begin{array}{l}\text { Number of } \\
\text { parameters }\end{array}$} & \multirow{2}{*}{$\begin{array}{l}\text { Median } \\
\text { sensitivity }\end{array}$} & \multicolumn{3}{|c|}{ Estimated values for pilot points } \\
\hline & & & & Minimum & Median & Maximum \\
\hline \multicolumn{7}{|c|}{ Horizontal hydraulic conductivity } \\
\hline KX1 & Qvt & 23 & 0.00964 & 0.0004 & 9.80 & 30 \\
\hline KX2 & Qva & 21 & 0.00986 & 0.0100 & 44.24 & 500 \\
\hline KX3 & QC1 & 47 & 0.00118 & 0.0001 & 1.28 & 15.35 \\
\hline KX4 & QC1pi & 7 & 0.000587 & 2.0847 & 3.74 & 400.53 \\
\hline KX6 & QA1 & 31 & 0.0154 & 0.0100 & 6.19 & 500 \\
\hline KX7 & QC2 & 37 & 0.00078 & 0.0064 & 0.02 & 0.0324 \\
\hline KX8 & QA2 & 38 & 0.00274 & 0.0114 & 0.34 & 500 \\
\hline KX9 & QC3 & 42 & 0.000567 & 0.0010 & 0.002 & 0.00293 \\
\hline KX10 & QA3 & 34 & 0.001975 & 0.1941 & 13.44 & 500 \\
\hline KX11 & QC4 & 40 & 0.0005835 & 0.0013 & 0.002 & 0.00332 \\
\hline KX12 & Bedrock & 50 & 0.0006265 & 0.00001 & 0.00004 & 0.00032 \\
\hline \multicolumn{7}{|c|}{ Vertical hydraulic conductivity } \\
\hline KV1 & Qvt & 23 & 0.00422 & 0.0001 & 0.005 & 2 \\
\hline KV2 & Qva & 21 & 0.00132 & 0.0036 & 0.128 & 2.047 \\
\hline KV3 & QC1 & 47 & 0.0105 & 5.0E-06 & 0.010 & 3 \\
\hline KV4 & QC1pi & 7 & 0.000648 & 0.0418 & 0.061 & 0.0884 \\
\hline KV6 & QA1 & 31 & 0.00219 & 0.0010 & 0.045 & 6.5346 \\
\hline KV7 & QC2 & 37 & 0.00349 & 0.0002 & 0.010 & 0.3 \\
\hline KV8 & QA2 & 38 & 0.000734 & 0.0132 & 0.032 & 0.1827 \\
\hline KV9 & QC3 & 42 & 0.001665 & 0.00004 & 0.00035 & 0.0194 \\
\hline KV10 & QA3 & 34 & 0.0005535 & 0.0084 & 0.029 & 1.06495 \\
\hline KV11 & QC4 & 40 & 0.0006215 & 5.4E-06 & 0.00018 & 0.00135 \\
\hline KV12 & Bedrock & 50 & 0.0005595 & 0.000003 & 0.000005 & 0.000007 \\
\hline \multicolumn{7}{|c|}{ Storage coefficient } \\
\hline S1 & Qvt & 23 & 0.00162 & 0.1 & 0.162 & 0.5 \\
\hline $\mathrm{S} 2$ & Qva & 21 & 0.000594 & 5.0E-06 & 9.6E-06 & 1.3E-05 \\
\hline S3 & QC1 & 47 & 0.00101 & 5.1E-06 & 2.8E-05 & 5.0E-05 \\
\hline $\mathrm{S} 4$ & QC1pi & 7 & 0.000555 & 2.8E-06 & 4.0E-06 & 4.8E-06 \\
\hline S6 & QA1 & 31 & 0.000617 & 2.0E-06 & 3.5E-06 & 5.7E-06 \\
\hline S7 & QC2 & 37 & 0.000821 & $1.1 \mathrm{E}-06$ & $1.9 \mathrm{E}-05$ & 5.0E-05 \\
\hline S8 & QA2 & 38 & 0.0006025 & $1.1 \mathrm{E}-06$ & 3.4E-06 & 3.9E-05 \\
\hline S9 & QC3 & 42 & 0.000585 & 9.5E-07 & 2.7E-05 & 5.0E-05 \\
\hline S10 & QA3 & 34 & 0.000672 & $7.4 \mathrm{E}-07$ & 2.9E-06 & $1.2 \mathrm{E}-05$ \\
\hline S11 & QC4 & 40 & 0.000617 & 4.2E-06 & 2.9E-05 & 5.0E-05 \\
\hline $\mathrm{S} 12$ & Bedrock & 50 & 0.000621 & $1.5 \mathrm{E}-05$ & 3.1E-05 & 5.0E-05 \\
\hline
\end{tabular}




\section{Model Limitations}

A groundwater-flow model represents a complex, natural system with a set of mathematical equations that describe the groundwater-flow system. Intrinsic to the model is the error and uncertainty associated with the approximations, assumptions, and simplifications that must be made. Hydrologic-modeling errors typically are the consequence of a combination of (1) input data, (2) representation of the physical processes by the algorithms of the model, and (3) parameter estimation during the calibration procedure (Troutman, 1985). Examples of the three types of model errors and how those errors limit application of the model are

1. Input data on types and thicknesses of hydrogeologic units, water levels, and hydraulic properties represent only approximations of actual values. Modeldiscretization errors (including effects of averaging elevation information over the model cell size) result from inaccuracies in the geometric representation of hydrogeologic units, in the representation of the bedrock areas and their contact with unconsolidated units, and location of the fault zone. In addition, the generalized conceptual model for the Kitsap Peninsula likely introduces error in the amount of water that flows beneath Port Orchard.

2. All the physical processes within a watershed cannot be represented completely or "captured" in a numerical model. Determining if a weakness in a simulation is attributable to input data error or model shortcomings is almost impossible, but the simplifying assumptions and generalizations that are incorporated into a model undoubtedly affect the results of the simulation.

3. Errors in parameter estimates occur when improper values are selected during the calibration process. Various combinations of parameter values can result in low residual error, yet improperly represent the actual system. An acceptable degree of agreement between simulated and measured values does not guarantee that the estimated model-parameter values uniquely and reasonably represent the actual parameter values. The use of nonlinear regression and associated statistics, such as composite scaled sensitivities and correlation coefficients, removes some of the effects of non-uniqueness, but does not eliminate the problem entirely.

If the regional groundwater-flow model is used appropriately, the effects of the simplifications and other potential errors can be limited. If the model is used for simulations beyond which it was designed, however, the generalizations and assumptions used could significantly affect the results. Because of the model scale and level of detail, the model generally is most applicable to analysis of regionalscale groundwater problems. Local scale heterogeneity in hydrologic properties, recharge, and discharge are not represented adequately by the regional-scale, groundwaterflow model constructed for this study.

\section{Model Applications}

The calibrated model is an appropriate tool to estimate components of the Island's groundwater budget and estimate the response of the groundwater system to changes in future pumpage and recharge conditions. Water-resource managers can then use that information to inform decisions about future groundwater management. The uncertainties associated with the model are carried forward to these model applications.

\section{Model-Derived Groundwater Budget}

An approximate groundwater budget for 2008 on the Island is expressed in the following equation:

$$
G W_{\text {in }}+R+S_{\text {in }}=G W_{\text {out }}+D+S_{\text {out }},
$$

where

$$
\begin{gathered}
G W_{\text {in }} \text { is groundwater inflow to the model area } \\
\text { (generally, lateral groundwater flow); } \\
R \text { is recharge; } \\
S_{\text {in }} \text { is groundwater coming in from storage; } \\
G W_{\text {out }} \text { is groundwater outflow from the model area } \\
\quad \text { (generally, lateral groundwater flow), } \\
D \text { is discharge; and } \\
S_{\text {out }} \text { is groundwater going out to storage. }
\end{gathered}
$$

Recharge to the groundwater system primarily occurs as recharge from precipitation and seepage from lakes, and secondarily, as seepage from septic systems. Discharge from the system occurs as seepage to streams, lakes, springs, and seepage faces; as evaporation from soils and transpiration by plants; as submarine seepage to Puget Sound; as groundwater outflow; and as withdrawals from wells. A more detailed representation of the groundwater budget of the Island is

$$
\begin{aligned}
G W_{i n} & +R_{p p t}+R_{s w}+S_{i n} \\
& =G W_{\text {out }}+D_{\text {sw }}+D_{e t}+D_{p p g}+S_{\text {out }},
\end{aligned}
$$

where

$$
\begin{aligned}
& R_{p p t} \text { is recharge from precipitation and septic } \\
& \text { returns, } \\
& R_{s w} \text { is recharge from lakes, } \\
& S_{\text {in }} \text { is amount taken in from storage, } \\
& D_{s w} \text { is discharge to surface-water features, } \\
& D_{e t} \text { is discharge by evapotranspiration, } \\
& D_{p p g} \text { is pumping from wells, and } \\
& S_{\text {out }} \text { is amount going out to storage. }
\end{aligned}
$$


All of the water-budget components can be quantified based on the calibrated model except discharge by evapotranspiration. Evapotranspiration from the groundwater (Det) is not known, but is assumed to be relatively insignificant to the total budget (assume Det $=0$ ) and therefore was not represented explicitly in the model.

The calibrated-model groundwater budget can be used to make some general observations of the groundwater system in 2008. Total flow through the groundwater system of the Island was about 31,000 acre-ft/yr (table 8). The principal form of groundwater recharge was from precipitation and septic-system returns. This number may increase as residential development continues due to increased septic-system returns. Groundwater inflow to the Island accounts for about 1,000 acre-ft/yr or slightly more than 5 percent of the recharge amount. Primary forms of groundwater discharge were to streams, lakes, springs, and seepage faces (16,000 acre-ft/yr) and as groundwater outflow to marine waters $(10,000$ acre-ft/ yr). Total groundwater withdrawals in 2008 were about 6.5 percent $(2,000 \mathrm{acre}-\mathrm{ft} / \mathrm{yr})$ of the total flow.

The groundwater budget indicates that the system was not at a steady-state condition during 2008, based on the difference between the Sin and Sout values. The net amount being withdrawn from storage is 10,000 acre-ft/yr. Below average precipitation was recorded in 2008, which led to below average recharge or 18,000 acre-ft/yr. Historically, recharge average is approximately $30,000 \mathrm{acre}-\mathrm{ft} / \mathrm{yr}$. Because recharge was below average in 2008, water was withdrawn from storage to balance the system.

Water budgets also were computed for the individual aquifer units on the Island for 2008 and predevelopment conditions (figs. 33A-B). Development of the groundwater system of Bainbridge Island predates any recorded waterlevel or streamflow measurements and, therefore, the predevelopment conditions of the aquifer system are unknown. The calibrated model was used to simulate groundwater conditions if no groundwater pumping or recharge from septic-system returns were occurring (that is, no inhabitation or predevelopment). Recharge values used in this simulation were estimated using the 30-year (1970-2000) average annual PRISM data.

All the aquifers withdrew water from storage during 2008 with the largest decrease occurring in the Qva aquifer; whereas, change in storage under predevelopment conditions was zero. Groundwater that flows out of the aquifers and discharges into Puget Sound has decreased in all aquifers from predevelopment conditions to 2008. Discharge to surface-water features also decreased during that period. The total amount withdrawn from storage for the five aquifers in 2008 was slightly more than $15 \mathrm{acre-ft/yr}$ as opposed to 10,000 acre-ft/yr for all of the units on the Island. This indicates that most of the water withdrawn from storage came from the confining units. For the QA3 aquifer under predevelopment conditions, lateral groundwater flow into the aquifer (641 acre-ft/yr) was about equal to downward
Table 8. Water budget for predevelopment and 2008 conditions, Bainbridge Island, Washington.

[Data are in acre-feet per year. Rate values are rounded.]

\begin{tabular}{|c|c|c|c|}
\hline In & Rate & Out & Rate \\
\hline \multicolumn{4}{|c|}{2008} \\
\hline $\mathrm{GW}_{\mathrm{in}}$ & 1,000 & $\mathrm{GW}_{\text {unt }}$ & 10,000 \\
\hline $\mathrm{R}_{\mathrm{pPT}}{ }^{\mathrm{IIT}}$ & 18,000 & $\mathrm{D}_{\mathrm{SW}}$ & 16,000 \\
\hline $\mathrm{R}_{\mathrm{sw}}$ & 0 & $\mathrm{D}_{\mathrm{et}}$ & 0 \\
\hline \multirow[t]{2}{*}{$\mathrm{S}_{\mathrm{in}}$} & 12,000 & \multirow{3}{*}{$\begin{array}{l}\mathrm{D}_{\mathrm{ppg}}^{\mathrm{el}} \\
\mathrm{S}_{\text {out }}\end{array}$} & 2,000 \\
\hline & & & 2,000 \\
\hline Total & 31,000 & & 31,000 \\
\hline \multicolumn{4}{|c|}{ Predevelopment } \\
\hline $\mathrm{GW}_{\mathrm{in}}$ & 1,000 & $\mathrm{GW}_{\text {out }}$ & 12,000 \\
\hline $\mathrm{R}_{\mathrm{ppT}}{ }^{\mathrm{In}}$ & 30,000 & $\mathrm{D}_{\mathrm{S} \text { out }}$ & 19,000 \\
\hline $\mathrm{R}_{\mathrm{sW}}$ & 0 & $D_{e t}$ & 0 \\
\hline \multirow{2}{*}{$S_{\text {in }}$} & 0 & $\mathrm{D}_{\mathrm{ppg}}$ & 0 \\
\hline & & $\mathrm{S}_{\text {out }}^{\mathrm{pus}}$ & 0 \\
\hline Total & 31,000 & & 31,000 \\
\hline
\end{tabular}

groundwater flow into the aquifer (642 acre-ft/yr) or 50 percent from each source. By 2008, lateral groundwater inflow was $364 \mathrm{acre}-\mathrm{ft} / \mathrm{yr}$, or 25 percent of the total and downward groundwater flow into the aquifer increased to $1,057 \mathrm{acre}-\mathrm{ft} / \mathrm{yr}$, or 75 percent of the total. The increased groundwater flow into the QA3 aquifer from the unit above can be attributed to pumping from the aquifer drawing more water into the unit.

The quantity of water that discharges naturally is not necessarily available for further groundwater development. Withdrawals superimposed on a previously stable system must be balanced by an increase in recharge, a decrease in the original discharge, a loss of storage within the aquifer, or by a combination of these factors (Theis, 1940; Bredehoeft and others, 1982). Additional withdrawals, therefore, would result in a loss of storage (with an attendant decline in water levels) and a decrease in natural discharge. Although the effects of additional groundwater withdrawals are somewhat mitigated by septic-system returns, there is still a net withdrawal of groundwater. Furthermore, an important factor regarding this secondary recharge is a probable decrease in groundwater quality associated with increasing volumes of secondary recharge. As discussed previously, not all natural discharge in the model area is to Puget Sound; a large quantity of groundwater discharges to streams, lakes, springs, and seepage faces. The magnitude of potential groundwater development, therefore, depends on the hydrologic effects on discharge that can be tolerated. Because the initial effect of pumping is to remove water from storage, the effect of capture of groundwater discharge might not be apparent for many months or even years after the onset of pumping. 
Simulated water bugets for individual aquifers (Units are acre-feet per year)

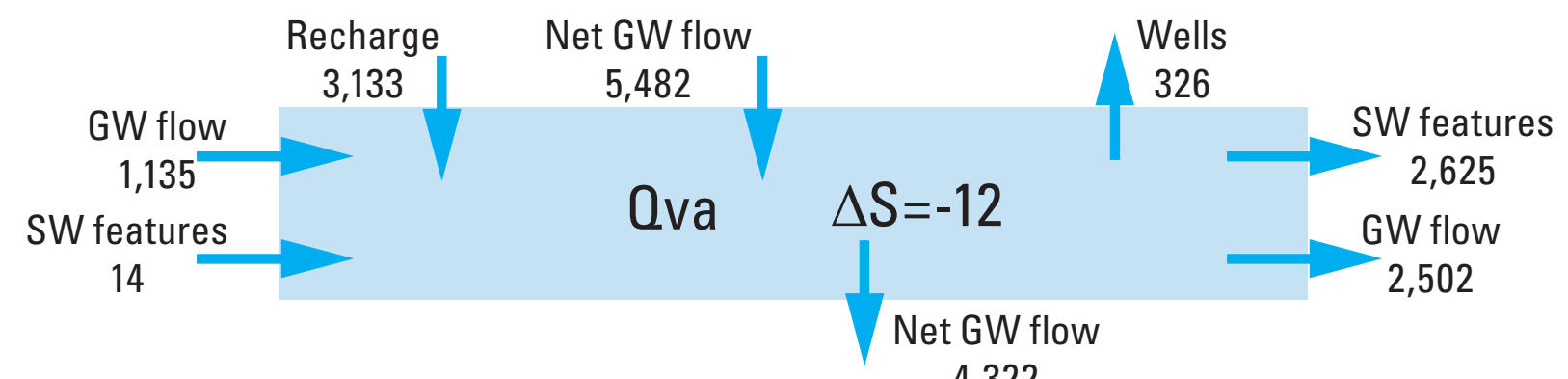

4,322
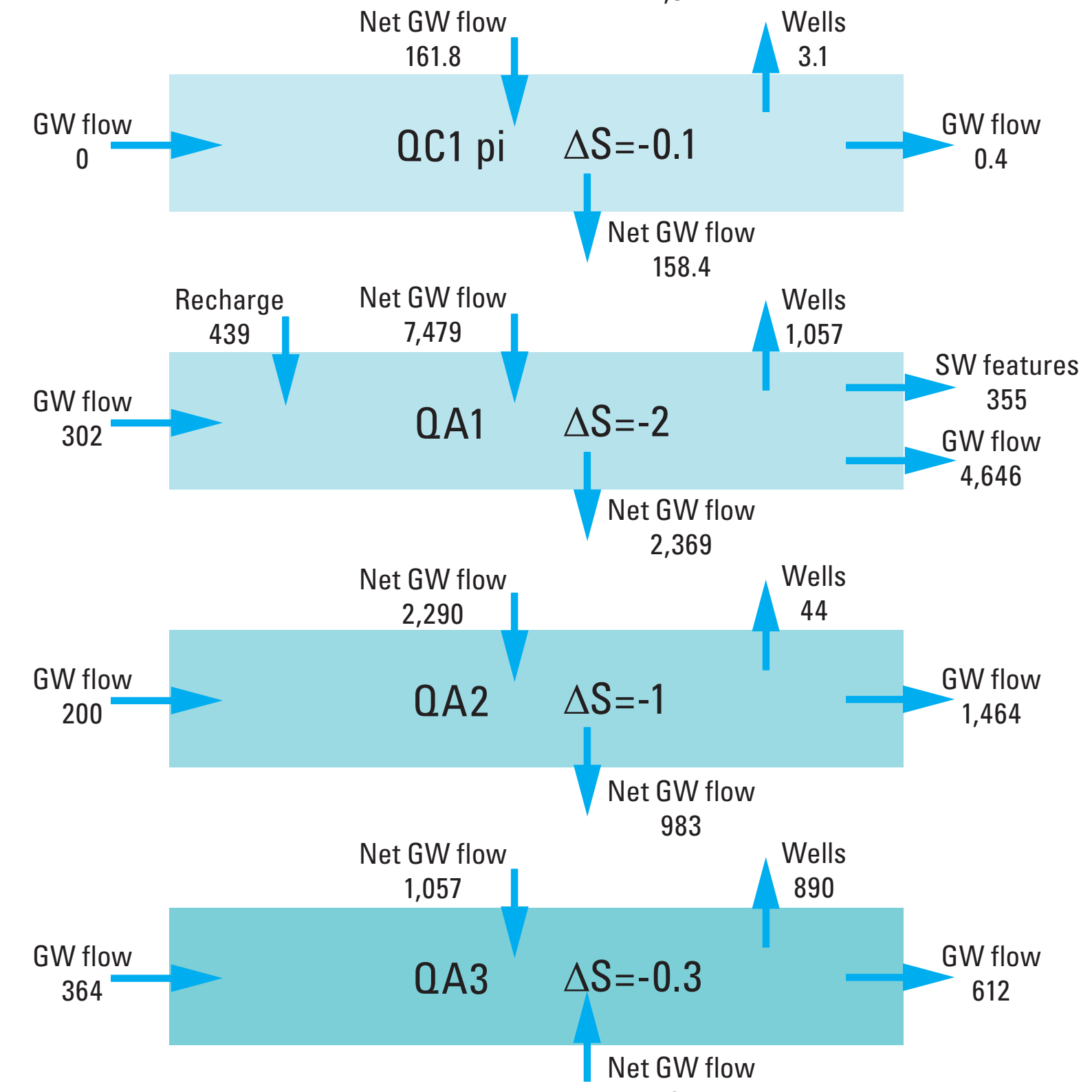

A. 2008

81

Figure 33. Simulated water budgets for individual aquifers for $(A) 2008$ and $(B)$ predevelopment conditions, Bainbridge Island, Washington. 
Simulated water bugets for individual aquifers

(Units are acre-feet per year)

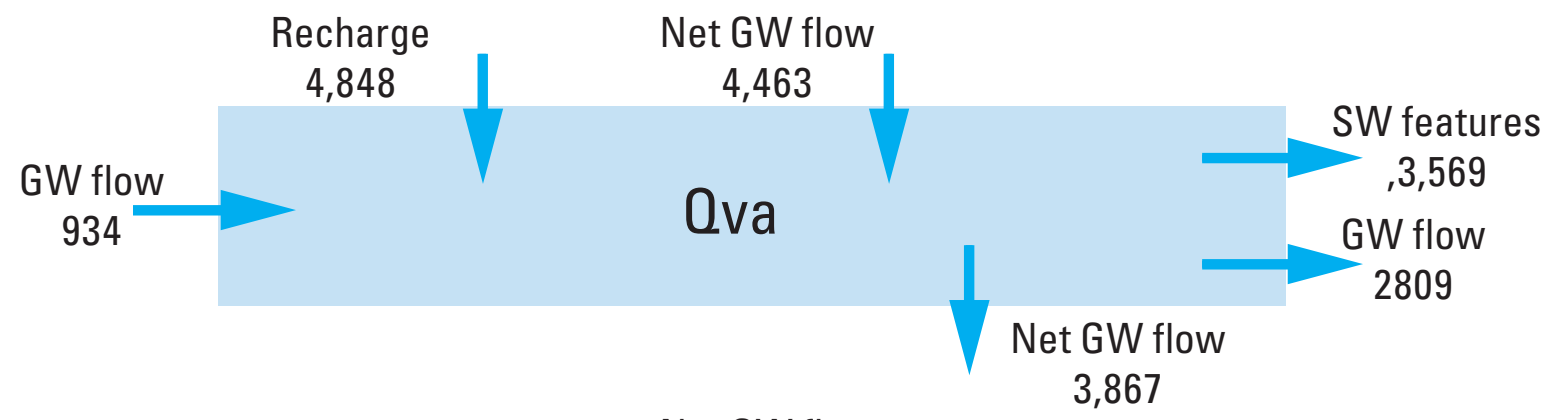

Net GW flow

3,867
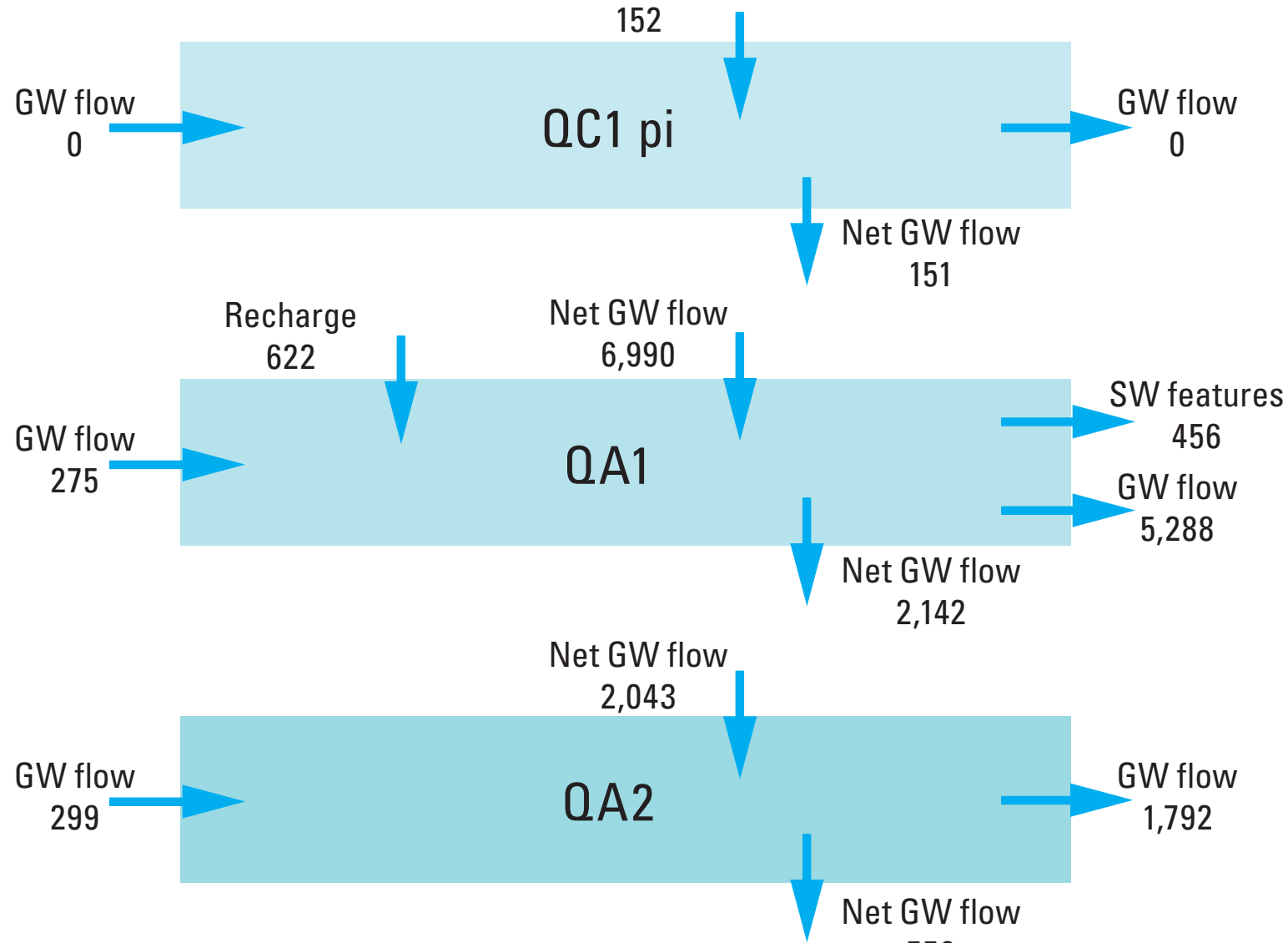

550

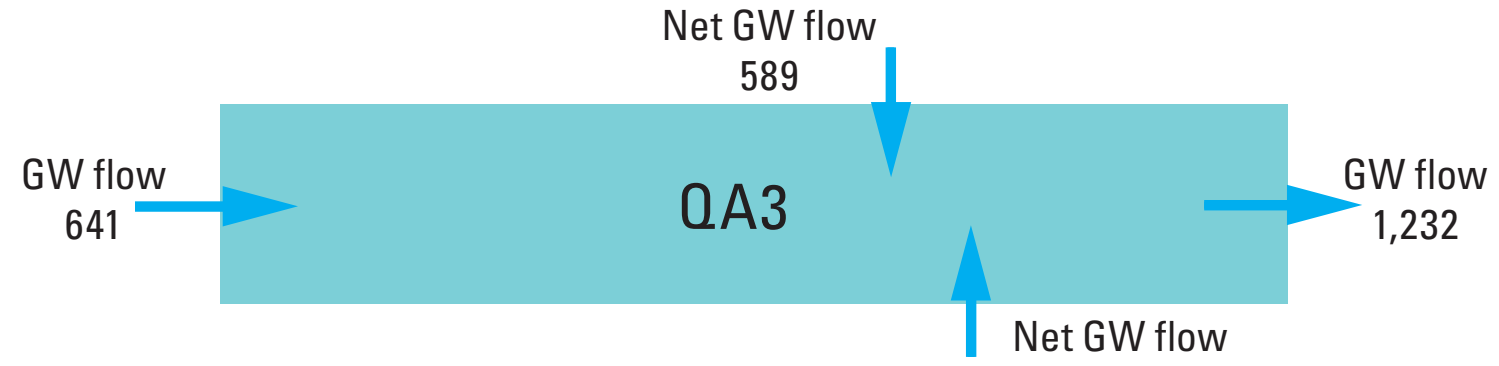

B. PREDEVELOPMENT

3

Figure 33.-Continued. 


\section{Simulation of Past and Future Groundwater Conditions}

An objective of constructing the model was to simulate what are termed scenarios. The purposes of the scenarios are to: (1) establish baseline conditions that likely represent predevelopment conditions and 2008 conditions to determine the effects of existing stresses (pumpage) on the groundwater system, (2) assess the potential effects of expected pumpage and climactic changes on the groundwater system, and (3) gain an understanding of the groundwater system under minimal and maximum stress (that is, extreme pumpage and climatic changes) during years 2009-35. Comparison of the predevelopment output to the 2008 simulation output provides the framework for assessing existing post-development effects, and comparison of the 2035 scenario output to the 2008 simulation output provides the framework for assessing potential future effects. Water-resource and community planning managers can use the resulting information to make informed decisions in their plan for future groundwater development and to assess the effects of environmental conservation or protection measures such as the protection of significant aquifer-recharge areas. Results are presented for the Qva, QA1, and QA3 aquifers as these are the principal drinking-water aquifers on the Island.

\section{Effects of Pumpage on Predevelopment Groundwater Conditions}

\section{Water Levels}

Simulated changes in groundwater levels since predevelopment for Qva, QA1, and QA3 are shown in figures $34 A-C$, respectively. The changes shown are from predevelopment to 2008 conditions. At the end of 2008, slightly higher water levels were in the Qva aquifer (fig. 34A) than under predevelopment conditions with an increase of greater than $5 \mathrm{ft}$ in some areas. This likely is due to the increased recharge from septic returns and to the decreased evapotranspiration from reductions in forest land cover. A small area in the center of the Island had declines of $10-20 \mathrm{ft}$ since predevelopment.

In some areas of the QA1 aquifer, groundwater levels were higher in 2008 compared to predevelopment conditions and some areas were lower (fig. 34B). Declines between zero and $10 \mathrm{ft}$ were measured in much of the aquifer and declines greater than $20 \mathrm{ft}$ were measured at small localized areas around the Island. These pockets of decline generally can be attributed to public-supply drinking water withdrawals.
Declines in water levels in the QA3 aquifer from predevelopment conditions ranged from about $10 \mathrm{ft}$ in the northeastern area of the Island to about $35 \mathrm{ft}$ on the western edge of the Island (fig. 34C). These declines are related to groundwater withdrawals for public-supply purposes. No saltwater intrusion was evident since predevelopment with the saltwater/freshwater interface remaining offshore. Sufficient recharge is present in all aquifers to push saltwater out of the aquifer system.

\section{Flow Direction}

For the most part, flow direction in the upper aquifers (Qva and QA1) has remained the same. However, inhabitation of the Island (and corresponding development on the Kitsap Peninsula) seems to have altered flow direction in part of the QA3 aquifer. Simulated predevelopment conditions indicate that, historically, the flow direction in the QA3 aquifer generally was from the west to the east (fig. 35). Simulated water-level contours for 2008 conditions, however, show a reversal of flow on the western side of the Island (fig. 32E). Only on the north end of the Island near Agate Passage to Port Madison and from the central part of the Island to the eastern shoreline does the flow continue to the east and northeast. Flow in the aquifer on the western side of the Island from Agate Passage now flows south to Manzanita Bay and west to Port Orchard Bay from the central area of the Island.

\section{Potential Groundwater Conditions in 2035}

Four model scenarios were identified for simulation from 2009 to 2035 (City of Bainbridge Island, 2009). These include the: (1) expected effect to the groundwater resources given the most probable changes in population growth, land use, and climate (expected impact scenario); (2) least potential effect to the groundwater resources given the lowest projected population growth and increased recharge due to changes in land use and climate (minimal impact scenario); (3) highest potential effect to the groundwater resources given the highest potential population growth and decreased recharge due to changes in land-use and climate (maximum impact scenario); and (4) protection of areas providing recharge for the City of Bainbridge Island water system wells combined with the expected impact scenario (recharge area conservation scenario). Note that the extreme population and climate change used in the maximum impact scenario are exaggerated in order to fully stress the groundwater system to observe the system under these conditions and do not represent any targeted or anticipated conditions. Results are presented for the Qva, QA1, and QA3 aquifers as these are the most widely used. 


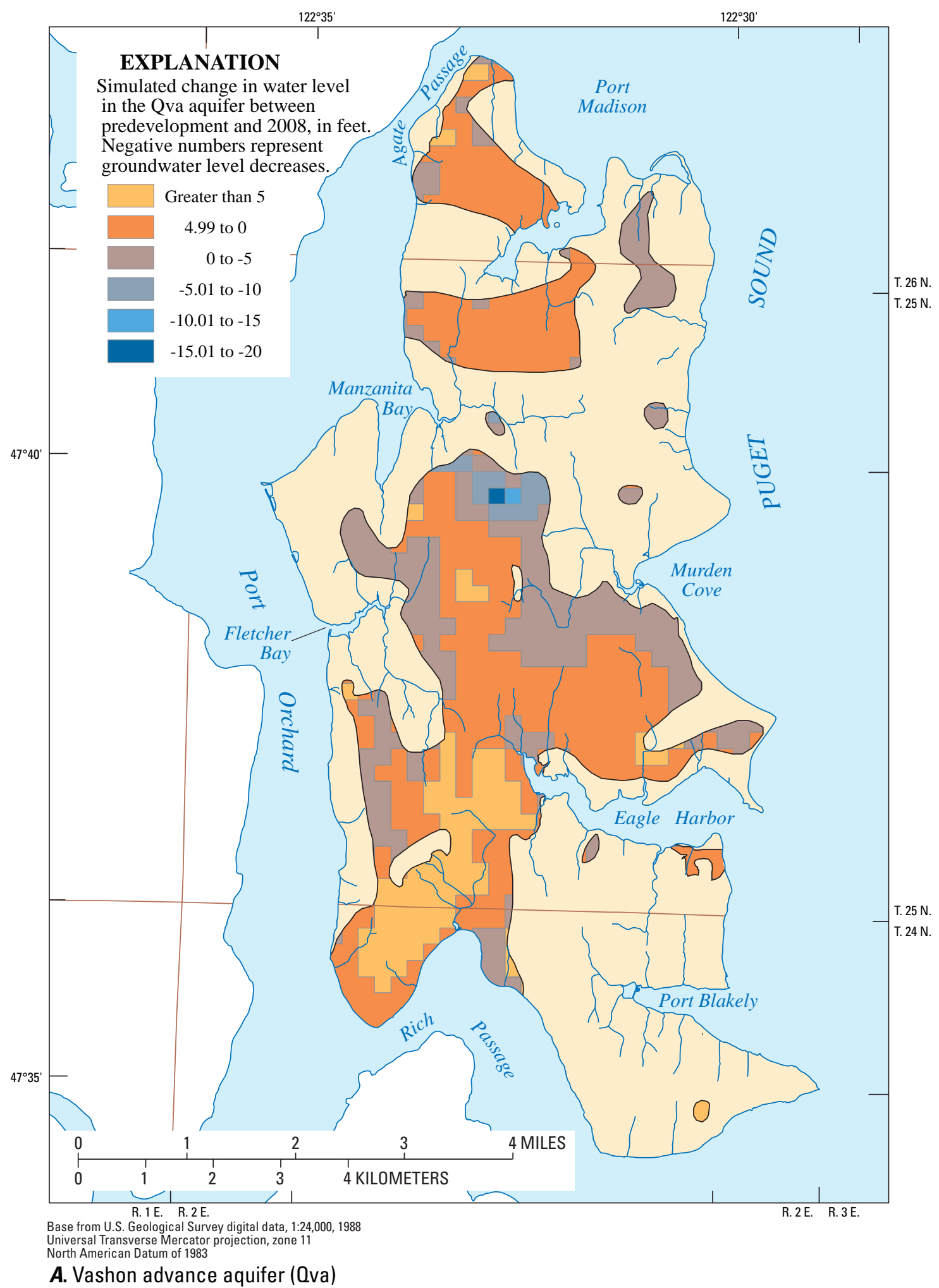

Figure 34. Simulated change in water levels between predevelopment and 2008 conditions in $(A)$ Vashon advance aquifer (Qva), (B) sea-level aquifer (QA1), and (C) deep aquifer (QA3), Bainbridge Island, Washington. 


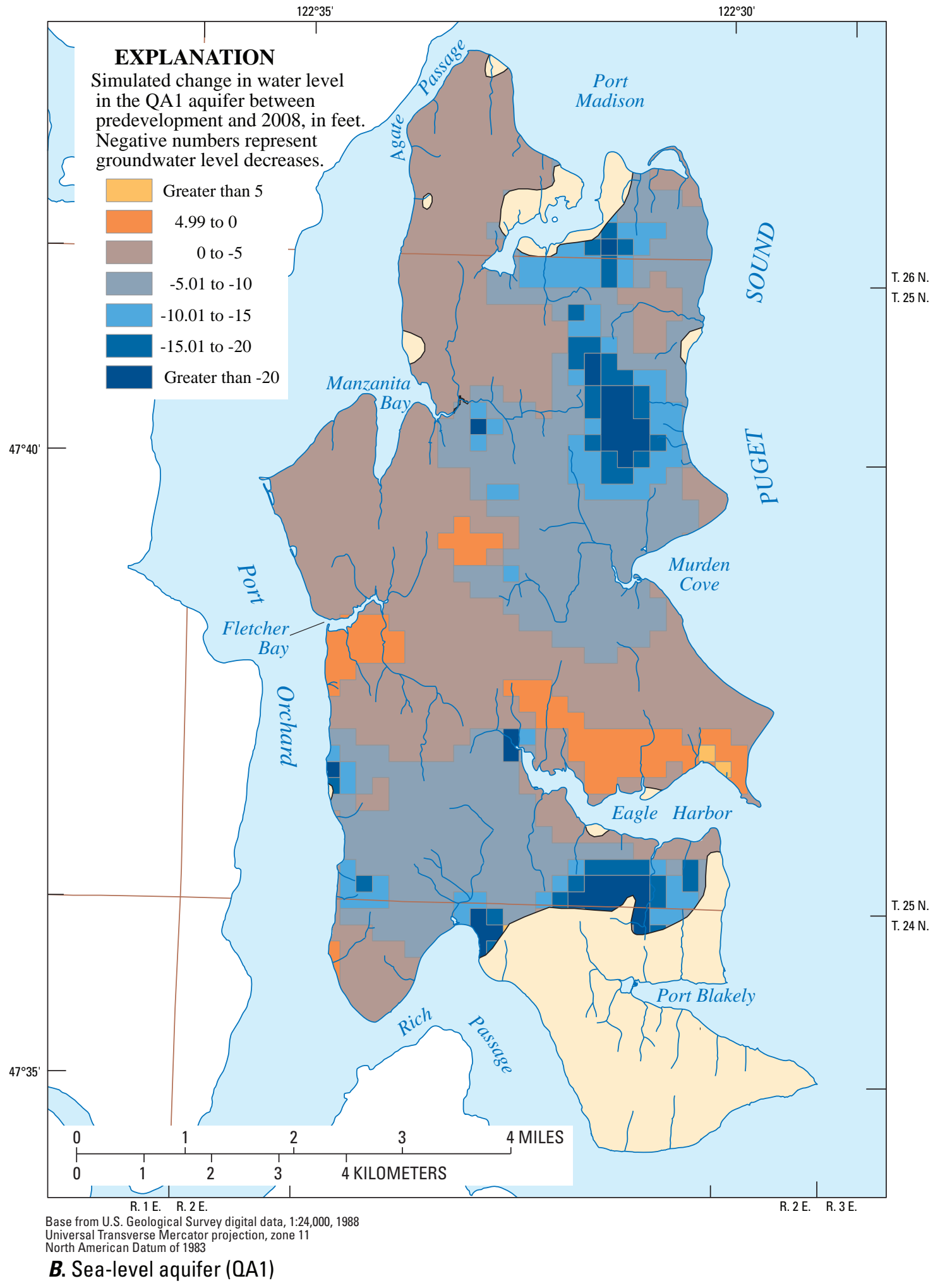

Figure 34.-Continued. 


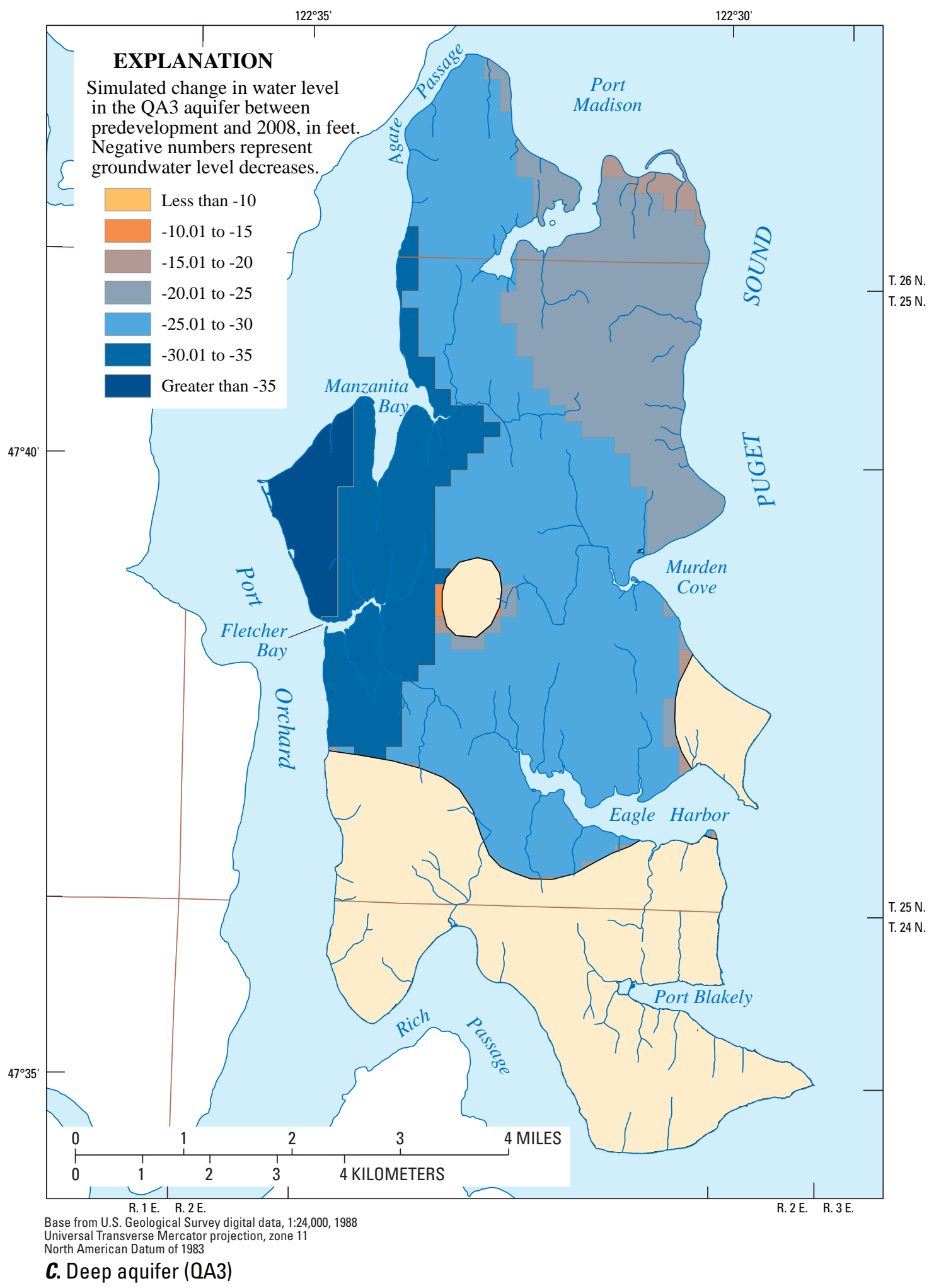

Figure 34.-Continued. 


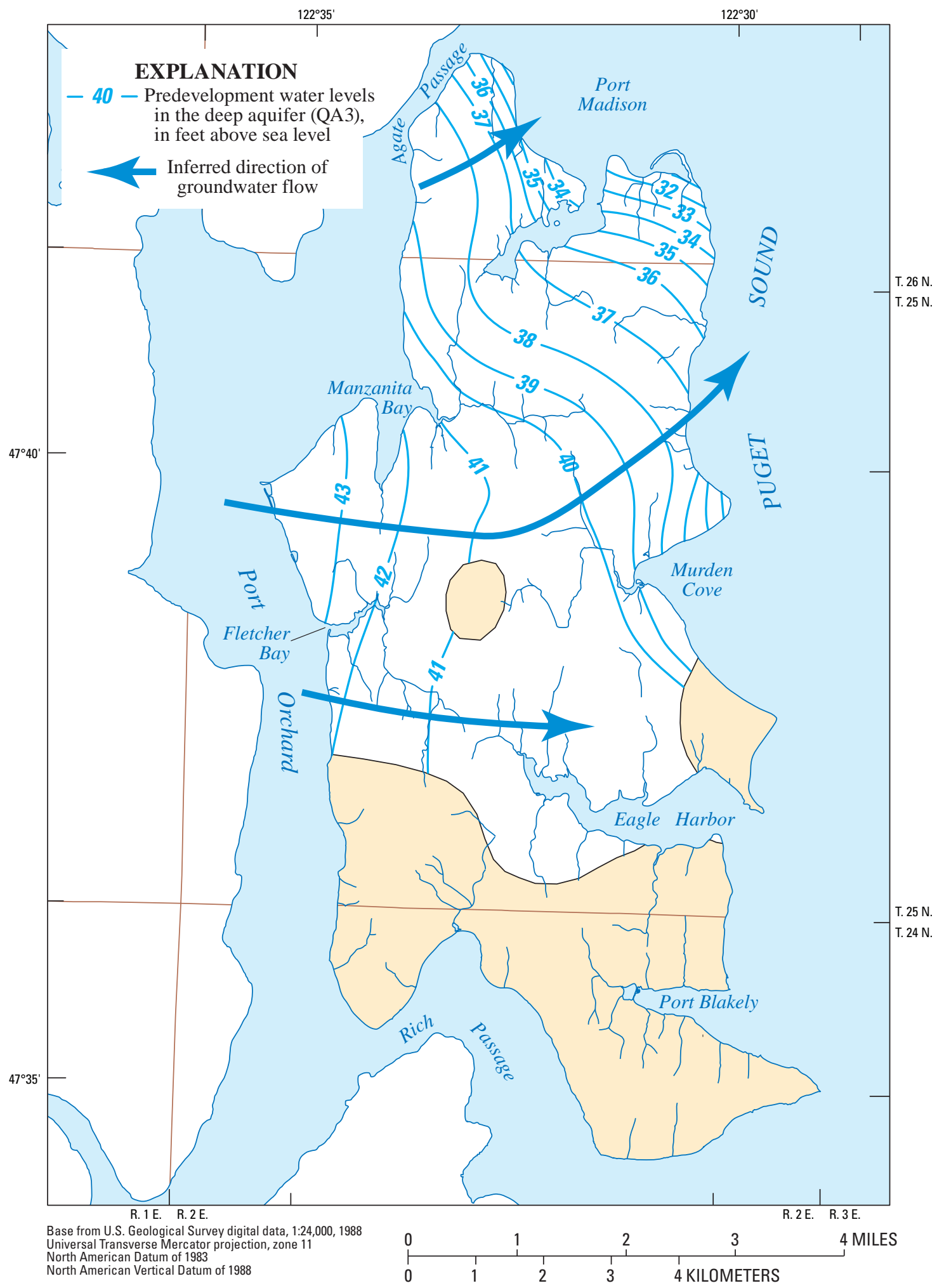

Figure 35. Simulated water levels and direction of groundwater flow under predevelopment conditions for the deep aquifer (OA3), Bainbridge Island, Washington. 
Population projections developed by the City of Bainbridge Island (2009) were used to estimate the increased pumpage required to support that population given existing per capita pumpage rates (fig. 36A). The population growth was distributed around the Island in accordance with the City of Bainbridge Island (2004) comprehensive plan and by using the City of Bainbridge Island (2009) Traffic Analysis Zones (TAZ). The increased pumpage was attributed to existing domestic and public-supply wells in each TAZ based on the expected increase in the number of people in that TAZ. The only exception to this method was for areas that lie within existing public-utility boundaries. For those areas, it was assumed that the public utility would supply the increased demand (City of Bainbridge Island, 2009). The relative distribution between the domestic and public-supply pumpage amounts was assumed to remain unchanged for future pumpage. Pumpage in wells on the Kitsap Peninsula was increased at the same rate as for the Island wells.

Future recharge (fig. 36B) was estimated based on the 30-year normal (1971-2000) PRISM data, adjusted for projected changes in land-use and climate scenarios. Downscaled results for temperature and precipitation from a list of 21 Global Climate Model (GCM) forecasts (Climate Impacts Group, 2010) were compiled for four future dates (2016, 2023, 2029, and 2035), with numeric averages used for the expected impact scenario and $\pm 1 \sigma$ (standard deviation) values used for the minimal impact scenario and the maximum impact scenario. Precipitation changes ranging from -3.9 to +7.0 percent were applied directly to the recharge rates. Temperature increases from 0.77 to $2.67^{\circ} \mathrm{F}$ were used to estimate changes in evapotranspiration using the DPM model with 2008 land-cover conditions. Land-use projections assembled by the City of Bainbridge Island (2009) were applied to the climate-adjusted recharge rates, to account for localized growth of impervious surfaces in areas designated for each of the three population growth scenarios. In areas projected to experience population growth without sewer services, septic returns were added to recharge at a rate of 70 percent of per capita use multiplied by the projected population in each TAZ (City of Bainbridge Island, 2009).

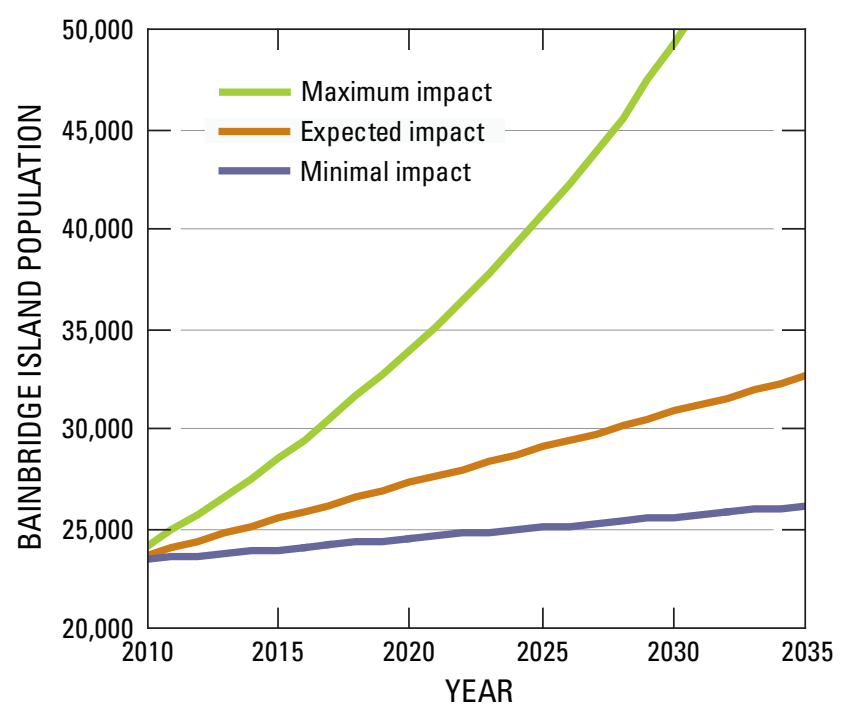

A. Projected population growth

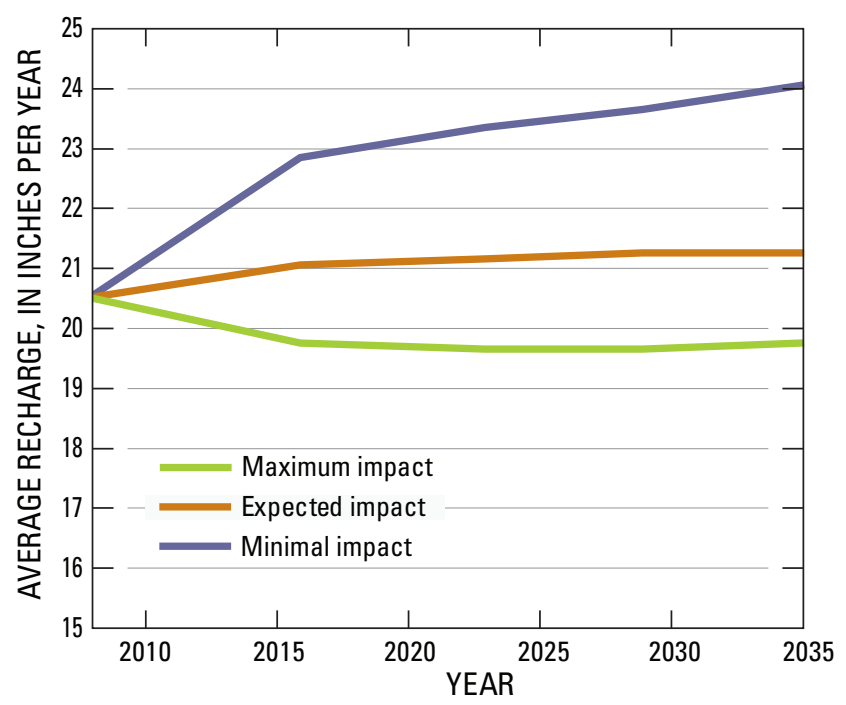

B. Projected recharge amounts

Figure 36. Projected $(A)$ population growth and $(B)$ recharge amounts for the minimal, expected, and maximum impact scenarios for the Bainbridge Island, Washington. 


\section{Expected Impact Scenario}

Expected increases in pumpage and changes to recharge due to changes in climate and land cover generally result in simulated water-level changes in the aquifers in the range of 0-15 ft. The shallow Qva aquifer had mild declines between zero and $5 \mathrm{ft}$ from 2008 to 2035 for most of the extent of the unit on the Island, and one isolated pocket of declines up to $25 \mathrm{ft}$ on the southwestern area of the Island north of Rich Passage (fig. 37A).

The QA1 also had mild declines between zero and $5 \mathrm{ft}$ for most of the central and northern areas of the Island with isolated pockets of declines between $10 \mathrm{ft}$ and $20 \mathrm{ft}$ south of Port Madison in the north and north of Rich Passage in the south. These larger changes in water levels occurred in areas where larger increases in pumping are projected to occur. As was seen in the comparison between predevelopment and 2008 conditions, some general areas such as northwest of Murden Cove, south of Eagle Harbor, and along the western coastline had continued increases up to $5 \mathrm{ft}$ due to the slightly increased recharge that occurs with this scenario (fig. 37B).

The decrease in water-levels in the QA3 aquifer ranged from less than 4 to $10 \mathrm{ft}$ (fig. 37C). Water-level changes were highest on the western side of the Island and lowest in the northeast, which is similar to the pattern observed between predevelopment and 2008 conditions. The decrease in water levels in Qva and QA1 is attributed to increased pumpage on the Island because flow in these units is isolated from the Kitsap Peninsula. Conversely, the decrease in water levels in QA3 is attributed to increased pumpage on the Island and the Kitsap Peninsula.

The flow-reversal pattern in the QA3 aquifer has changed further compared to the 2008 conditions. Under 2008 conditions, the flow direction, based on the water-level contours in the southern end of the QA3 aquifer was radially off the Island (fig. 32E). By 2035, flow is expected to be radially off the Island to the west and east only in the center of the aquifer and reversed in the southern part of the aquifer so that flow is from the east to the west (fig. 38). No saltwater intrusion was simulated to occur by 2035 under the expected impact scenario with the saltwater/freshwater interface remaining offshore.

\section{Minimal Impact Scenario}

In the minimal impact scenario in which pumpage is increased the least and recharge is increased the most, waterlevel changes were less than in the expected impact scenario (figs. 39A-C). For the Qva aquifer, the water-level decreases simulated under the minimal impact scenario are slightly less than under the expected impact scenario with a decline of slightly more than $10 \mathrm{ft}$ north of Rich Passage on the south end of the Island. For this scenario, water levels in most of the aquifer would increase as much as $5 \mathrm{ft}$ or decrease less than $5 \mathrm{ft}$.

A similar pattern of water-level changes was simulated under the minimal impact scenario as under the expected impact scenario for the QA1 aquifer. Much of the aquifer will have increases in water levels of as much as $5 \mathrm{ft}$ (fig. 39B). Water-level decreases of less than $5 \mathrm{ft}$ are expected in the general areas north of Eagle Harbor, south of Fletcher Bay, and from Manzanita Bay northeast to Port Madison with water-level decreases from 15 to $20 \mathrm{ft}$ near Rich Passage.

The QA3 aquifer generally would have water-level declines of up to $5 \mathrm{ft}$ with the minimal impact scenario, mostly in the southwestern part of the unit (fig. 39C). No saltwater intrusion was simulated to occur by 2035 under the minimal impact scenario with the saltwater/freshwater interface remaining offshore. 


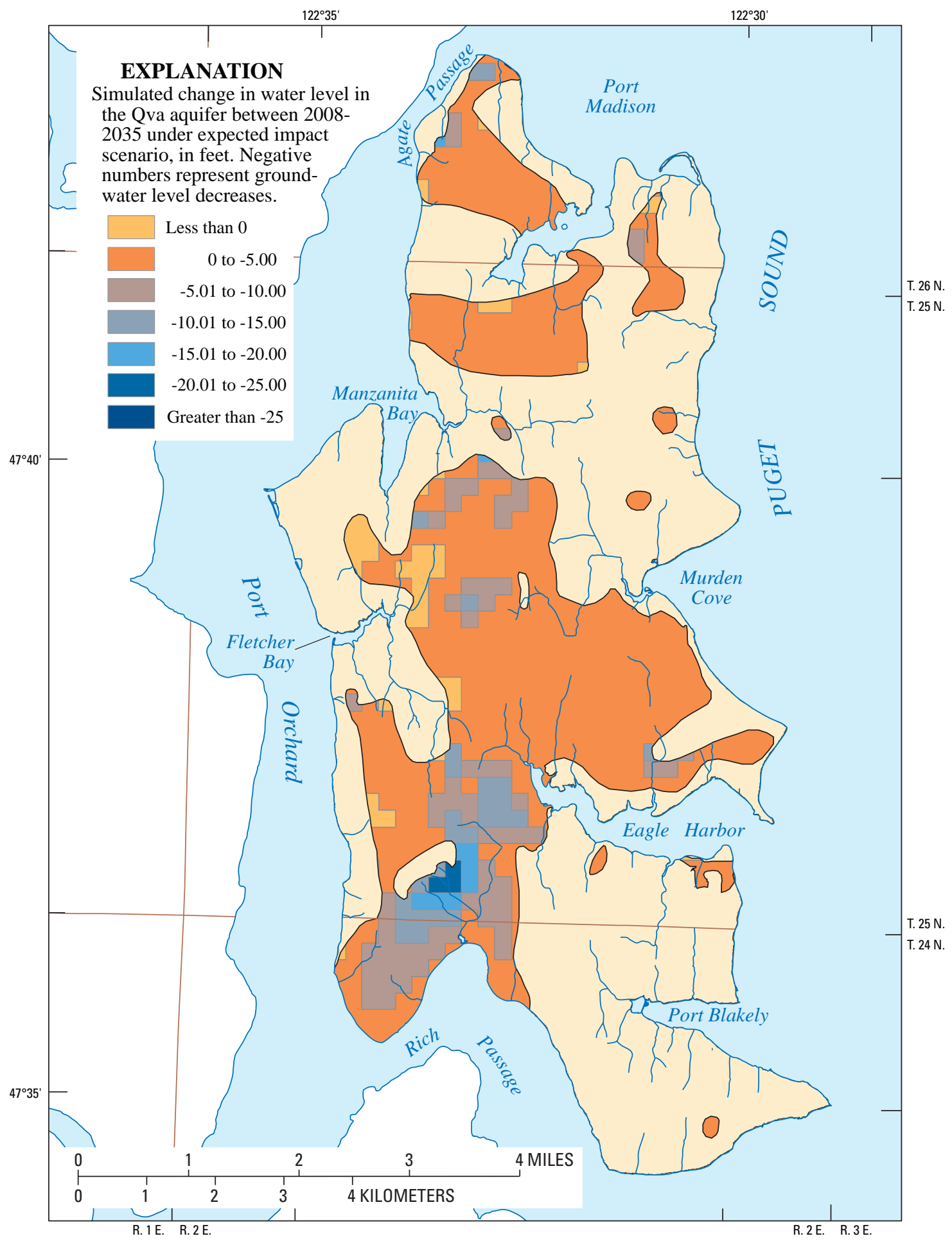

\section{A. Vashon advance aquifer (Qva)}

Figure 37. Simulated change in water level between 2008 and 2035 under expected impact scenarios for $(A)$ Vashon advance aquifer (Qva), $(B)$ sea-level aquifer (QA1), and (C) deep aquifer (QA3),

Bainbridge Island, Washington. 


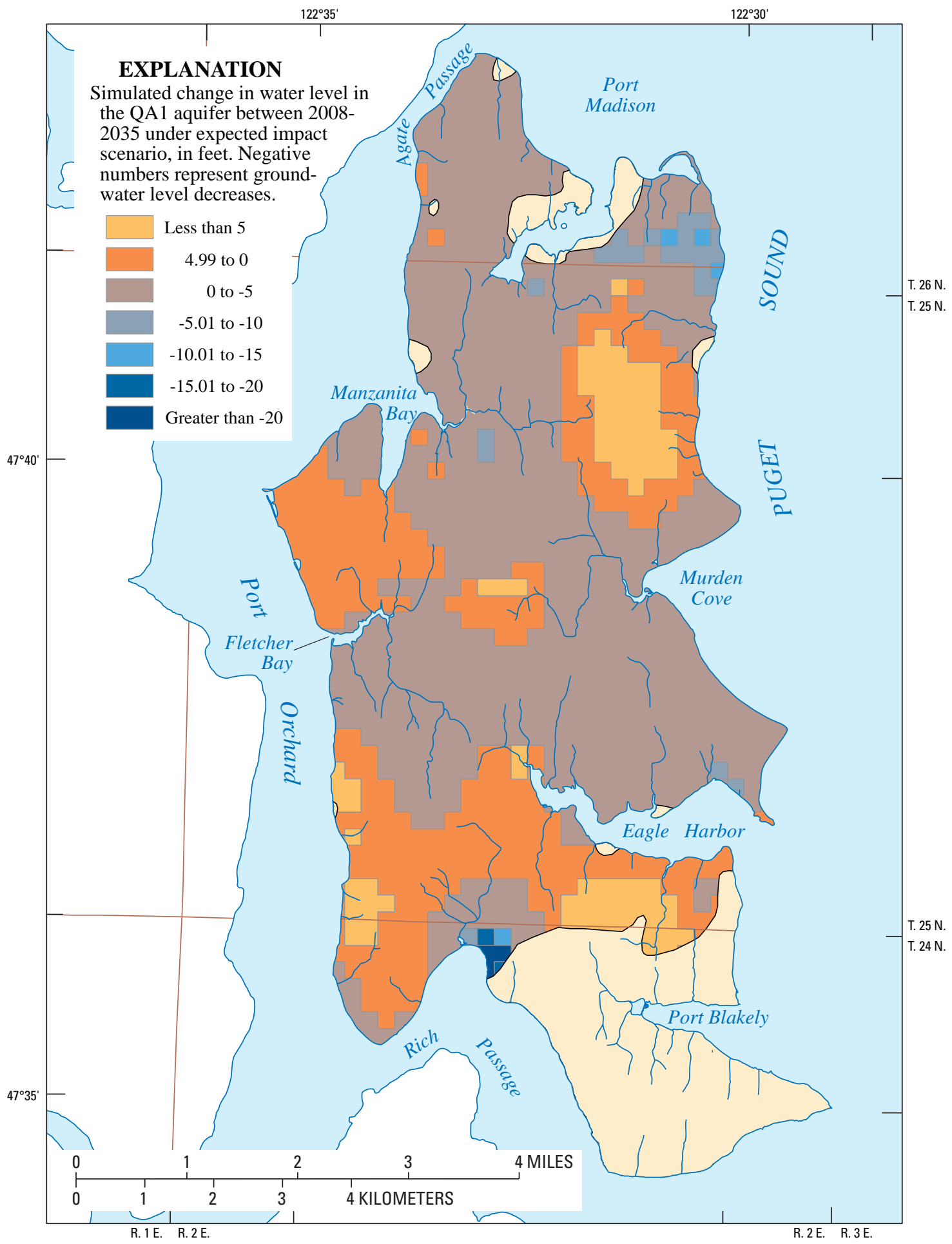

B. Sea-level aquifer (OA1)

Figure 37.-Continued. 


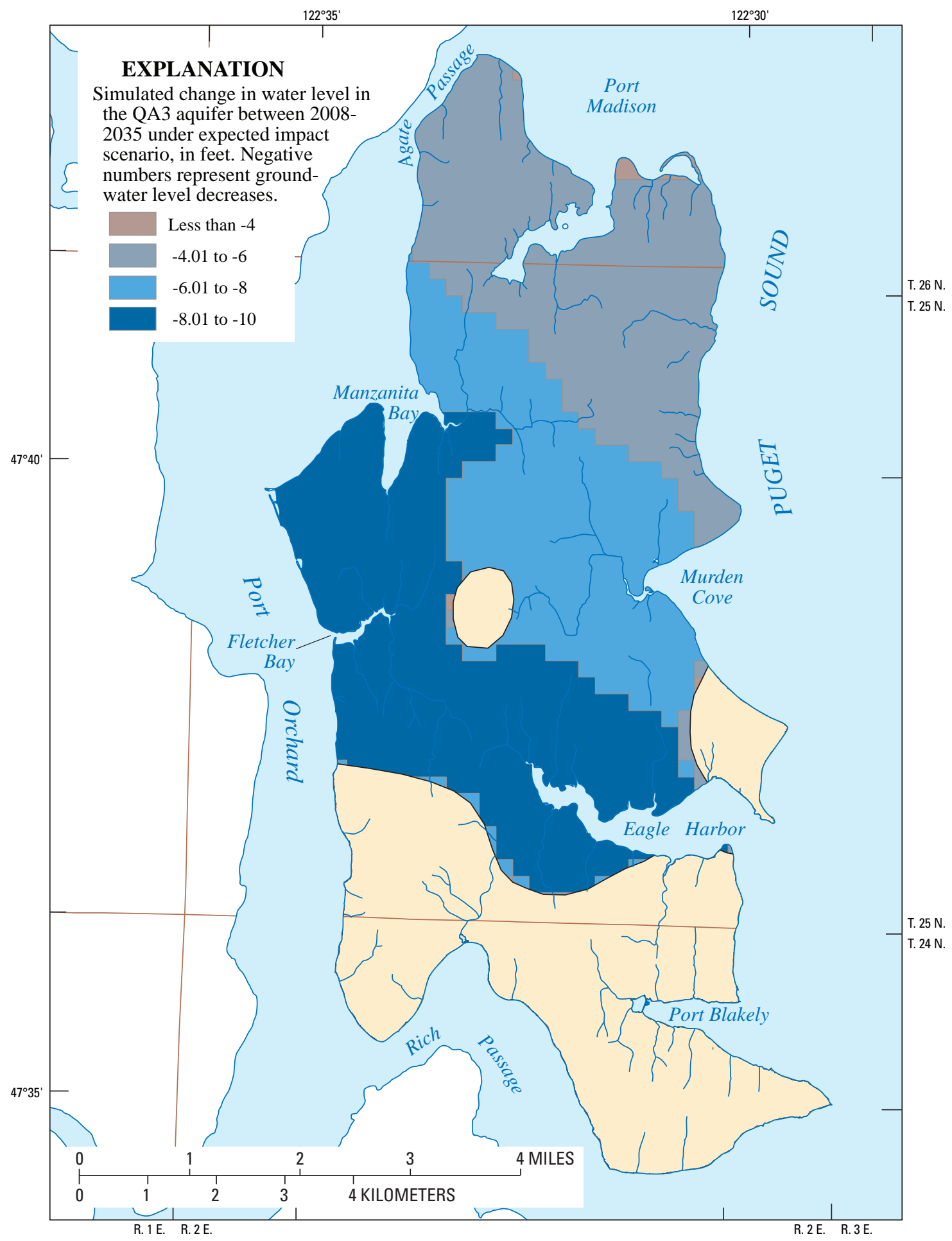

C. Deep aquifer (OA3)

Figure 37.-Continued. 


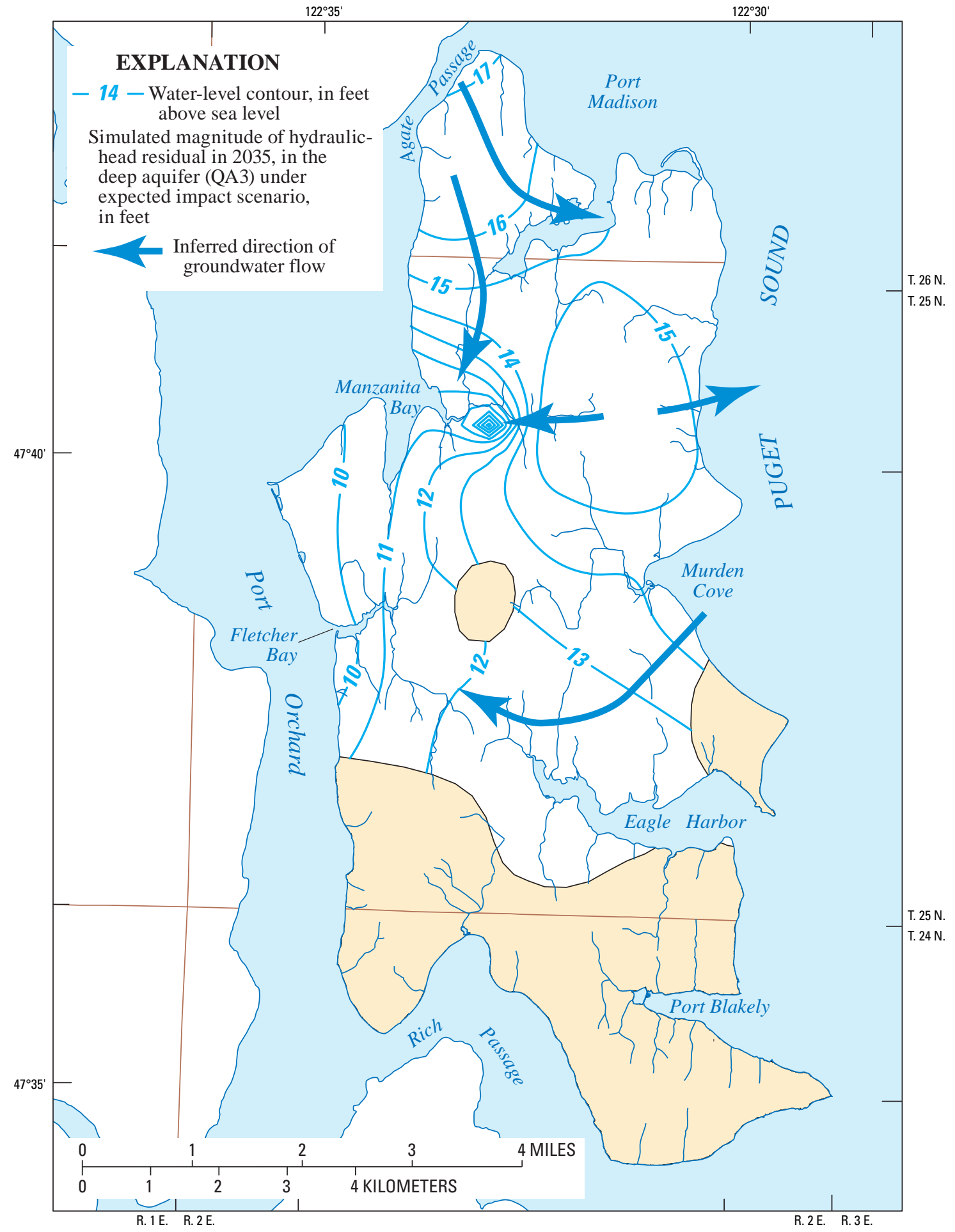

Figure 38. Simulated water level and direction of groundwater flow in 2035 under the expected impact scenario for the deep aquifer (0A3), Bainbridge Island, Washington. 


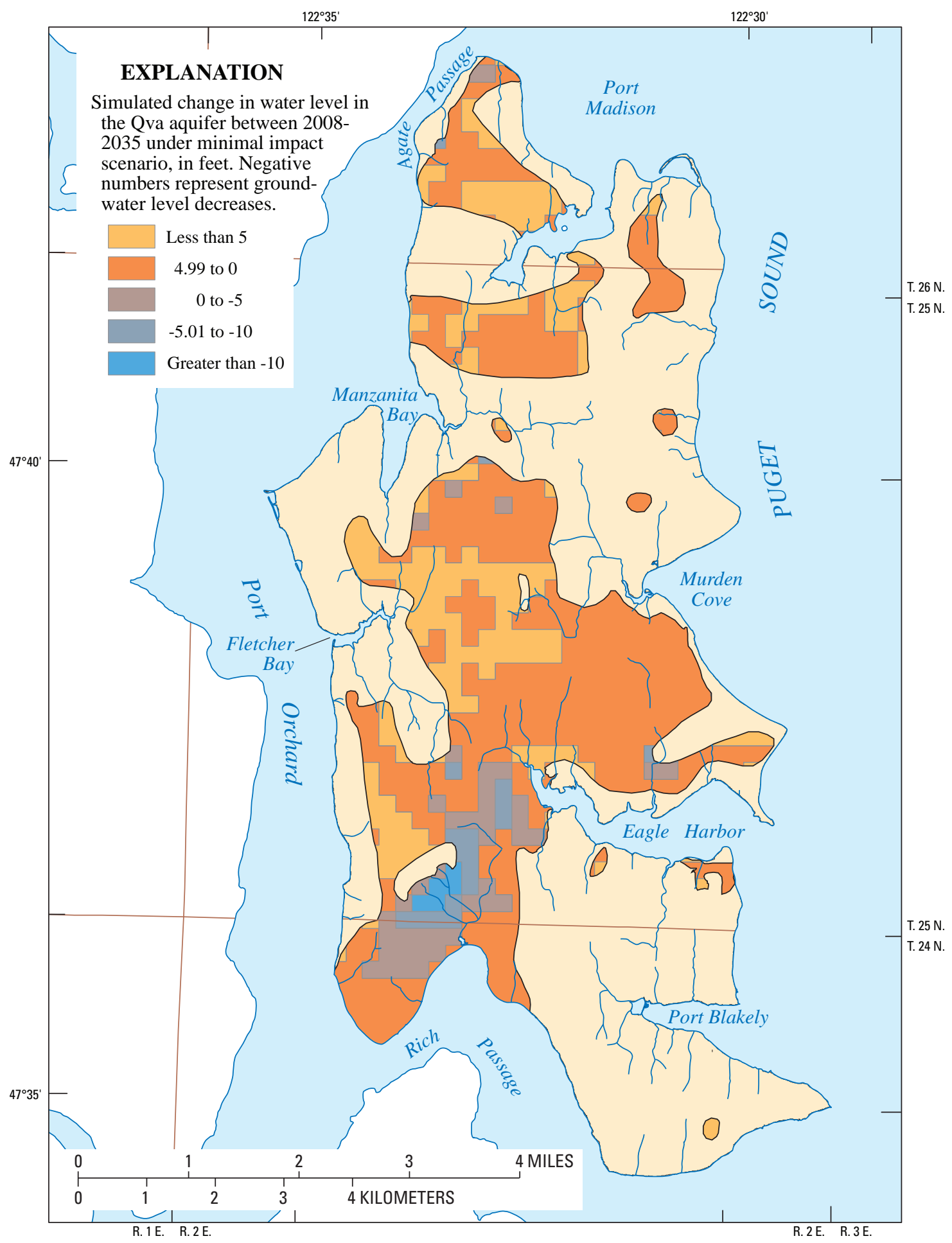

A. Vashon advance aquifer (Ova)

Figure 39. Simulated change in water level between 2008 and 2035 under the minimal impact scenario for the $(A)$ Vashon advance aquifer (Ova), $(B)$ sea-level aquifer ( $Q A 1)$, and $(C)$ deep aquifer (QA3), Bainbridge Island, Washington. 


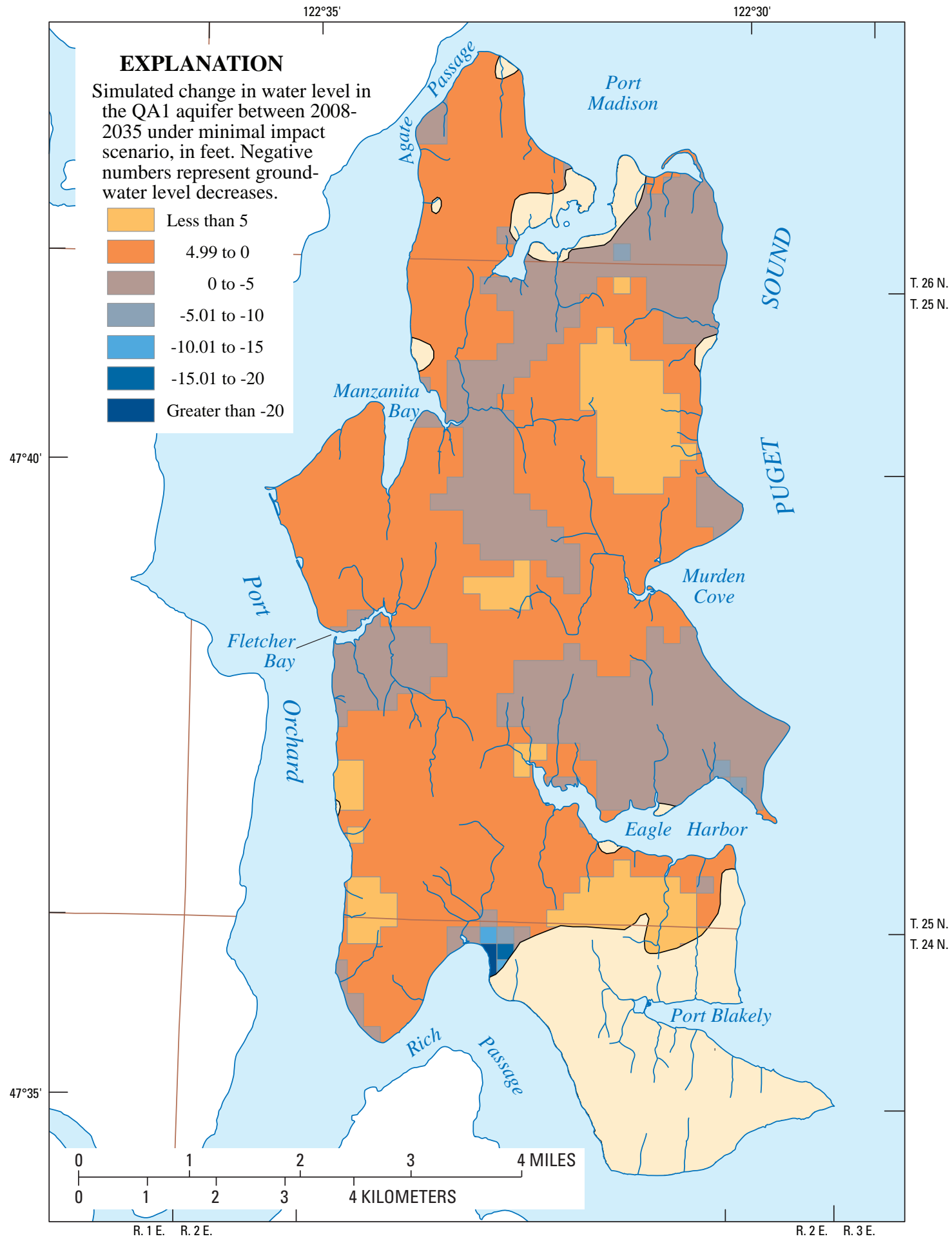

B. Sea-level aquifer (OA1)

Figure 39.-Continued. 


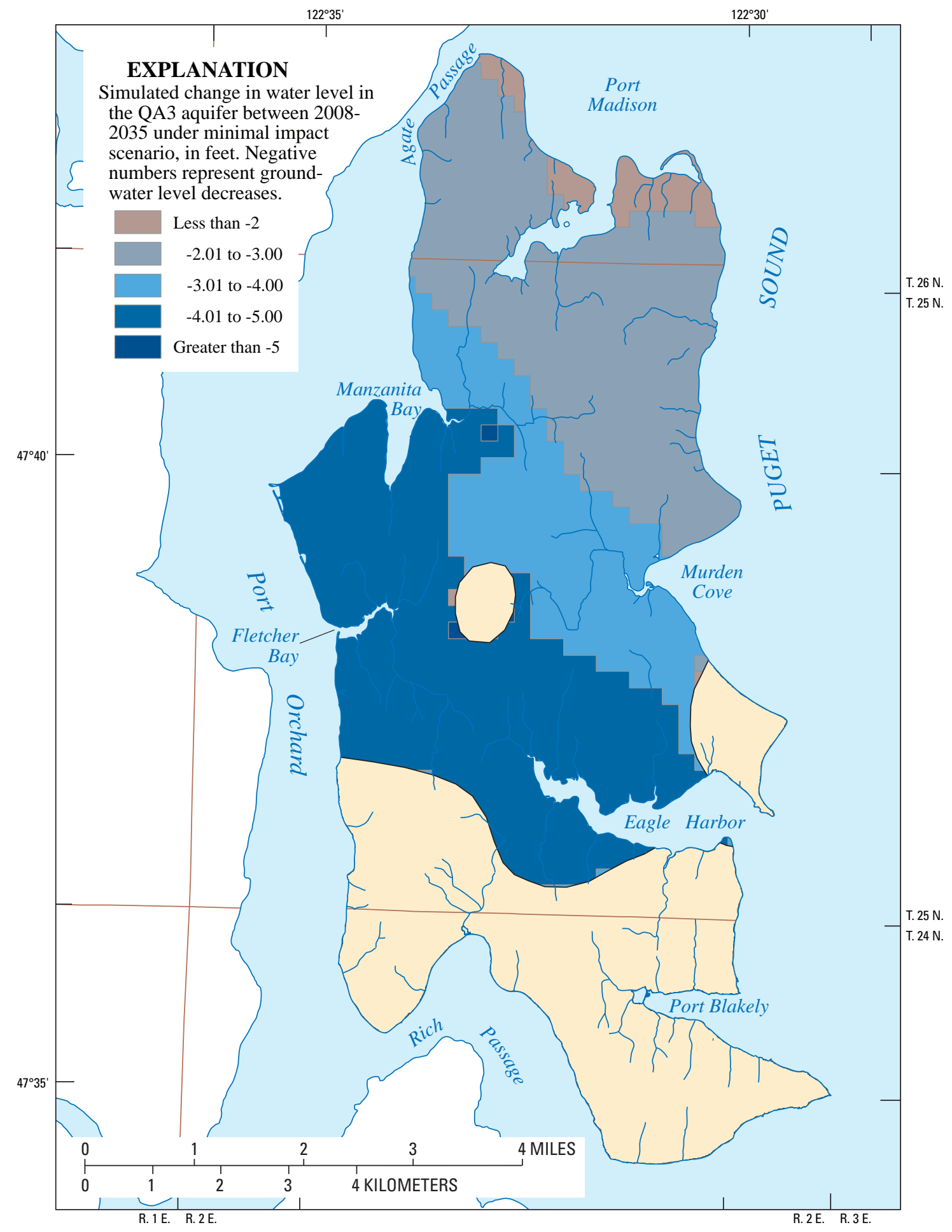

C. Deep aquifer (QA3)

Figure 39.-Continued. 


\section{Maximum Impact Scenario}

The maximum impact scenario represents purposely exaggerated population growth and the most severe reduction in recharge that the Island might experience by 2035 . This scenario simulates how the groundwater system might respond under the most extreme stresses, but does not reflect anticipated conditions.

Under this scenario, the decrease in water levels in the Qva aquifer is slightly more than under the expected impact scenario (fig. 40A). Declines in the water level are projected to be less than $10 \mathrm{ft}$ for most of the aquifer with isolated pockets of declines in water levels that exceed 10-15 ft with some areas having increases as much as $5 \mathrm{ft}$.

In the QA1 aquifer, declines in water levels are typically projected to be less than $10 \mathrm{ft}$ for most of the unit (fig. 40B). A larger percentage of the unit would have declines in water levels between 10 and $20 \mathrm{ft}$ with isolated pockets in excess of $20 \mathrm{ft}$, particularly near Port Madison and Rich Passage.

In the QA3 unit, water-level declines are substantially higher under the maximum impact scenario than under the expected or minimal impact scenarios (fig. 40C). Water-level declines range from a minimum of $10 \mathrm{ft}$ in the northeast corner of the Island to more than $40 \mathrm{ft}$ on the western edge of the Island. As with the expected impact scenario, the large decline in water levels are attributed to substantially increased pumpage on the Island and Kitsap Peninsula to the point where the simulated groundwater-flow direction may reverse entirely so that all flow in this aquifer is from east to west rather than with some of the flow from west to east as is simulated for 2008 (fig. 41). No saltwater intrusion was simulated to occur by 2035 in any aquifer under the maximum impact scenario with the saltwater/freshwater interface remaining offshore. However, given the flow reversal that was simulated to occur in QA3 under these conditions, saltwater intrusion likely would occur in that aquifer unit along the northern and eastern coastlines at a future date under continued exposure to these conditions.

\section{Protection of Recharge Areas Scenario}

Protection of areas that contribute recharge for wells that provide water for the City of Bainbridge Island watersupply system is of interest to the city. The contributing areas were delineated using the post-processing, particle-tracking computer code, MODPATH (Pollock, 1994), to backtrack simulated groundwater-flow paths from the areas of discharge to the points of recharge. Once the contributing areas were delineated, the expected growth scenario was rerun with those model cells within the contributing-recharge areas being protected from future land-use changes.

\section{MODPATH Procedure}

The computer code MODPATH uses a semianalytical, particle-tracking scheme. The method is based on the assumption that each directional-velocity component (calculated from MODFLOW output) varies linearly within each model cell. This assumption allows an analytical expression describing the flow path within each cell to be obtained using the simulated flows through the faces of the cell. The velocity of groundwater is affected by the porosity of the material through which the groundwater is flowing. Specified porosities were 0.2 for till, 0.3 for sand and gravel aquifers, and 0.4 for clay-rich confining units (Fetter, 1994). Given the initial position of a particle, the position of the particle at any future time can be calculated. A series of calculations for successive locations of a particle provide a picture of its path through the cell and into adjacent cells if appropriate. See Pollock (1994) for a detailed discussion of the procedure. MODPATH requires initial locations of the particles to be tracked. Particles were placed closely around each well or well field (if multiple wells were located in close proximity) using a horizontal ring of particles in each model layer penetrated by a screened interval of well or well field. The rings contained 200 particles each and were placed at the altitude of the center of the cell. The simulation was run for 1,000 years using 2008 conditions to locate areas that were expected to contribute the bulk of the recharge in the future.

\section{Simulated Recharge Areas for Protection}

The City of Bainbridge Island has several wells in different aquifers on the Island. The Head of the Bay well field withdraws water from the QA1 aquifer. The MODPATH simulation indicates that water withdrawn from this well field comes from areas to the west and north near the headwaters of an unnamed stream (locally known as Springbrook Creek) which flows into Fletcher Bay and an unnamed stream (locally known as Cooper Creek) which flows into Eagle Harbor (fig. 42). No particles reached the surface within the 1,000-year simulation run time in wells that withdraw water from the QA2 and QA3 aquifers. No contributing areas were delineated for these wells, because these wells are withdrawing ancient water and protecting certain areas of the Island from land-use changes would have no effect on the water levels expected in these wells by 2035. The uncertainties associated with inaccuracies in the flow-system simulation are carried forward to these analyses and new uncertainties are introduced. Refer to the discussion of uncertainty in the 'Model Limitations' section of the report.

\section{Scenario Results}

A comparison of the land-use maps used to determine recharge rates indicated that no changes in land use are expected between 2008 and 2035 for those areas that contribute recharge to the city wells withdrawing water from the QA1 aquifer under the expected impacts scenario. Because the recharge rate did not change in the contributing-recharge areas, the amount of drawdown in the aquifers is identical for this scenario as for the 2035 expected impacts scenario. 


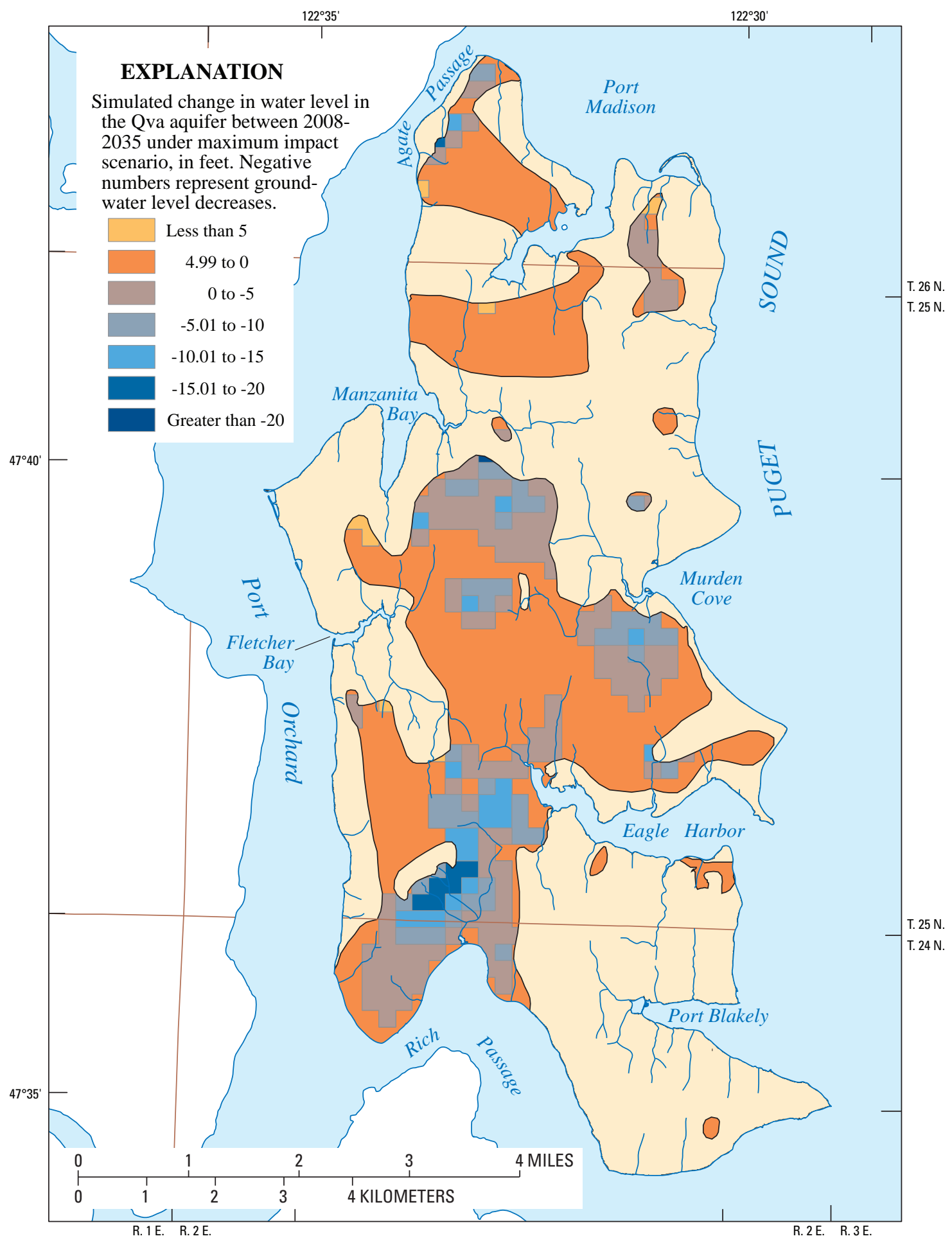

\section{A. Vashon advance aquifer (Qva)}

Figure 40. Simulated change in water level between 2008 and 2035 under the maximum impact scenario for the $(A)$ Vashon advance aquifer (Ova), (B) sea-level aquifer ( $0 A 1)$, and $(C)$ deep aquifer (QA3), Bainbridge Island, Washington. 


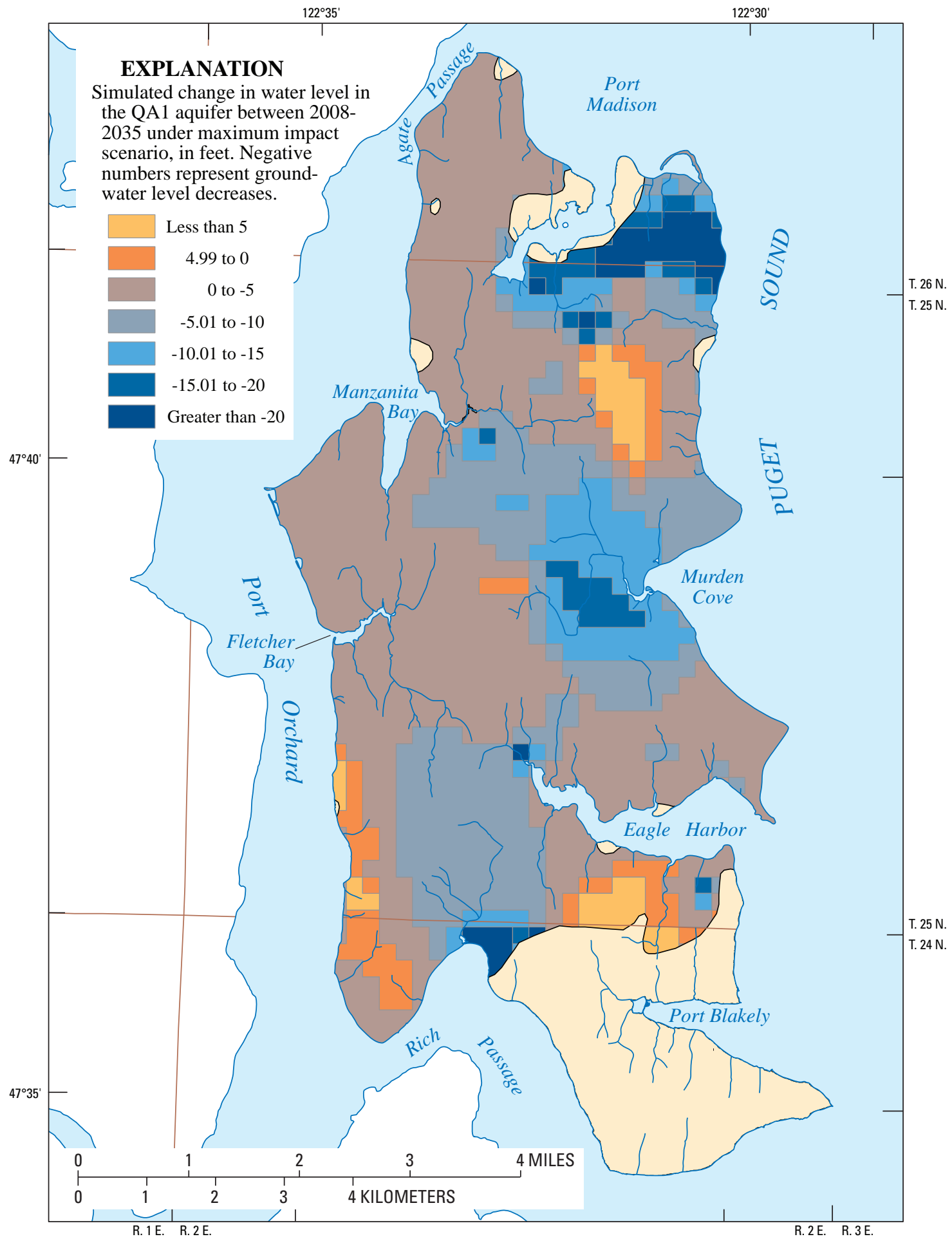

\section{B. Sea-level aquifer (OA1)}

Figure 40.-Continued. 


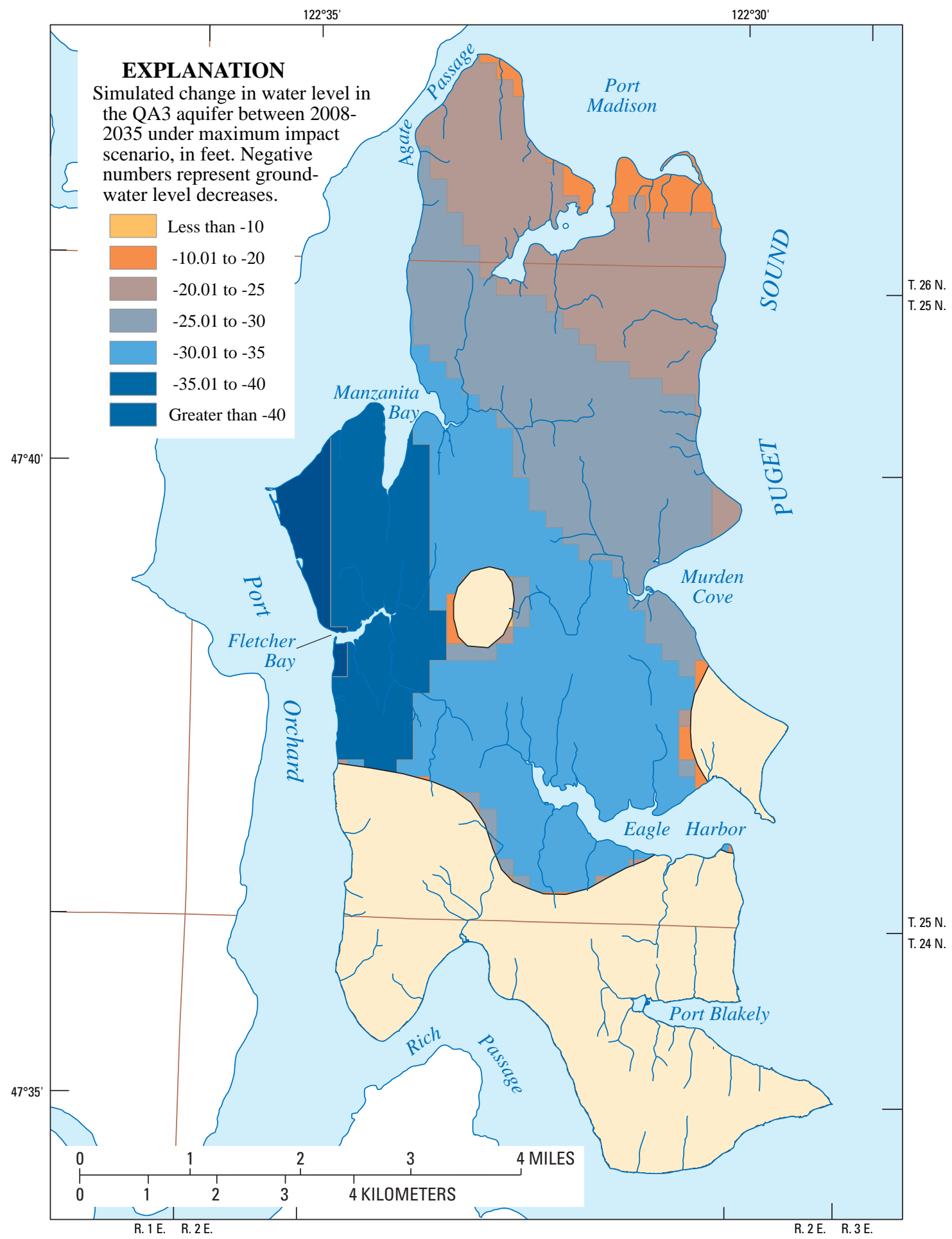

C. Deep aquifer (OA3)

Figure 40.-Continued. 


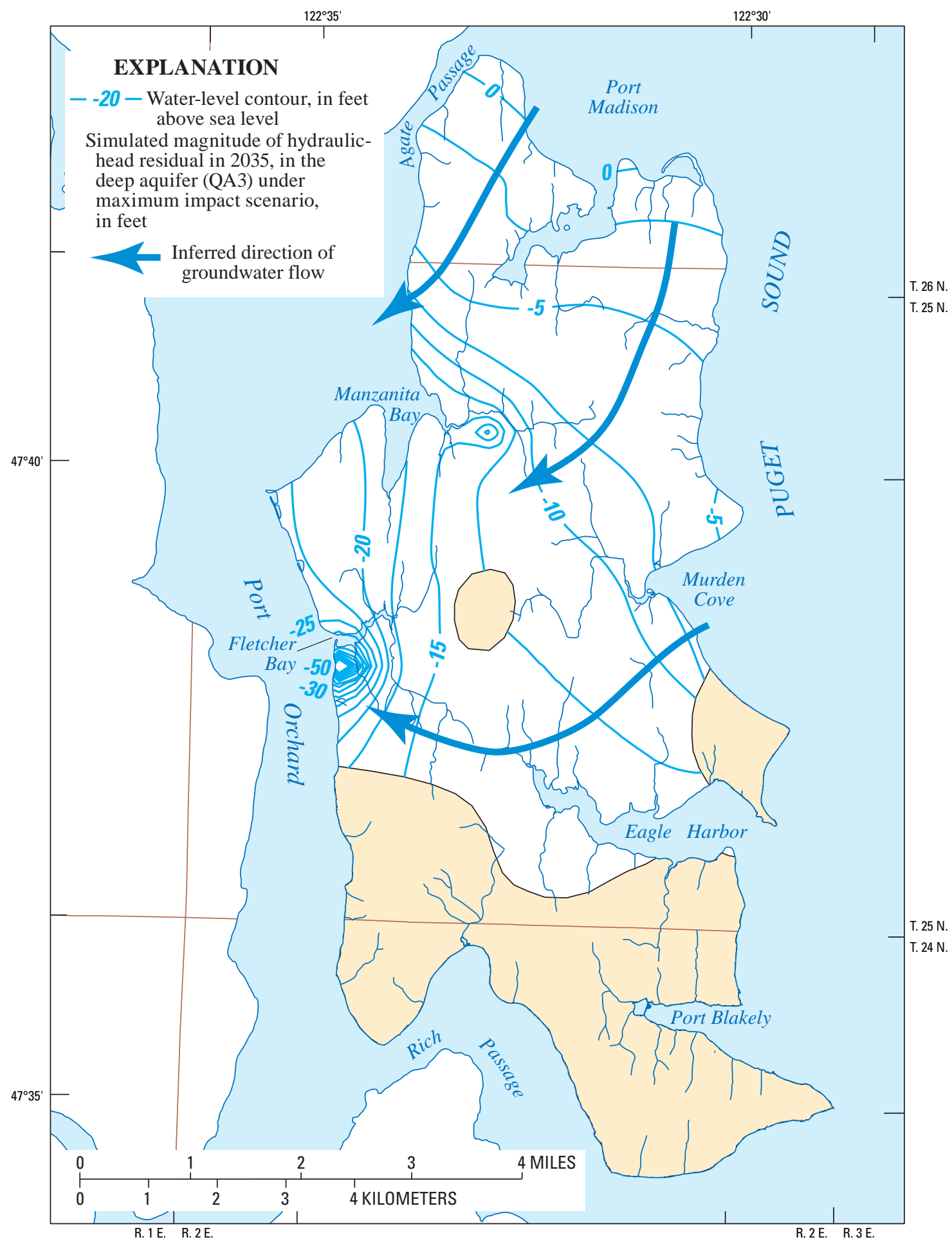

Figure 41. Simulated water level and direction of groundwater flow in 2035 under the maximum impact scenario for the deep aquifer (QA3), Bainbridge Island, Washington. 


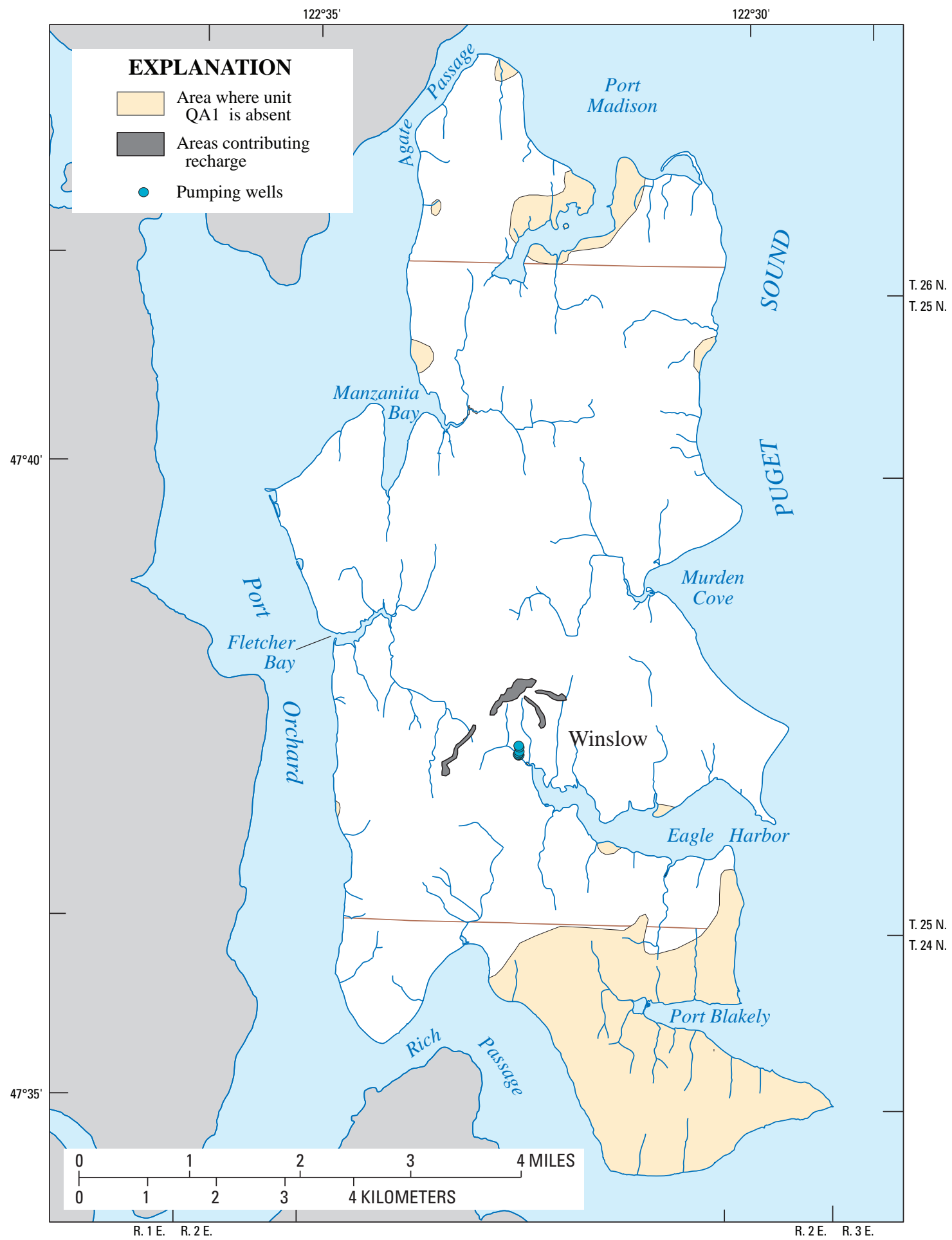

Figure 42. Simulated recharge areas for water pumped at the City of Bainbridge Island Head of the Bay well field, Washington. 


\section{Summary}

Groundwater is the sole source of drinking water for the population of Bainbridge Island. Increased use of groundwater supplies on Bainbridge Island as the population has grown over time has created concern about the quantity of water available and whether saltwater intrusion will occur in coastal wells as groundwater usage increases. Under the Water Resources Element of the comprehensive plan developed by the City of Bainbridge Island, "the protection of water resources is of primary importance to the Island.” A groundwater-flow model was developed to aid water-resources managers in the understanding of the groundwater system of Bainbridge Island and the potential effects of groundwaterdevelopment alternatives on the water resources of Bainbridge Island.

Bainbridge Island is underlain by unconsolidated deposits of glacial and nonglacial origin. The surficial geologic units and the deposits at depth were differentiated into aquifers and confining units on the basis of areal extent and general water-bearing characteristics. Eleven principal hydrogeologic units are recognized in the study area and form the basis of the groundwater-flow model.

A transient variable-density groundwater-flow model of Bainbridge Island and the surrounding area was developed to simulate 2008 groundwater conditions using SEAWAT. Thirtytwo model layers were used to simulate the unconsolidated sediments that overlie the bedrock and one layer was used to simulate the upper part of the bedrock. A no-flow boundary was used along the topographic high of the Kitsap Peninsula for the model boundary on the north, west, and southern boundaries and a general-head boundary was used on the model boundaries that occur below sea level. Constant-head cells were used where the model layers were in contact with Puget Sound. All major streams and lakes were included in the model as drains and general-head boundaries, respectively.

Groundwater recharge from precipitation was estimated for the Island using the Deep Percolation Model. Secondary recharge from septic-system returns was estimated based on the locations of pumping wells and their usage rates. Groundwater pumping from public-supply and domestic wells was included in the model.

The model was calibrated to water levels measured during 2007 and 2008 using PEST to minimize the weighted differences or residuals between simulated and measured hydraulic head. The simulated values generally matched the measured values for all units with the exception of the QC1pi unit, which generally was discontinuous with few wells present.

The calibrated model was used to make some general observations of the groundwater system in 2008. Total flow through the groundwater system was about 31,000 acre-ft/yr.
The primary form of groundwater recharge was from precipitation and septic-system returns. Groundwater flow to Bainbridge Island accounted for about 1,000 acre-ft/yr, or slightly more than 5 percent of the recharge amounts. Groundwater discharge was predominately to streams, lakes, springs, and seepage faces (16,000 acre-ft/yr) and directly to marine waters $(10,000$ acre-ft/yr). Total groundwater withdrawals in 2008 were about 6.5 percent (2,000 acre-ft/yr) of the total flow.

The calibrated model was used to simulate predevelopment conditions, during which no groundwater pumping or secondary recharge occurred and currently developed land was covered by conifer forests. Simulated water levels in the uppermost aquifer generally were slightly higher at the end of 2008 than under predevelopment conditions, likely due to increased recharge from septicsystem returns and decreased evapotranspiration due to reduced forest land cover. Simulated changes in water levels for the extensively used sea-level aquifer (QA1) were variable, although areas with declines between zero and $10 \mathrm{ft}$ were common and generally can be attributed to withdrawals from public-supply drinking wells. Simulated water-level declines in the deep (Fletcher Bay) aquifer between predevelopment and 2008 conditions ranged from about $10 \mathrm{ft}$ in the northeast to about $25 \mathrm{ft}$ on the western edge of the Island. These declines are related to groundwater withdrawals for public-supply purposes.

The calibrated model was used to simulate the possible effects of increased groundwater pumping and changes to recharge due to changes in land-use and climatic conditions between 2008 and 2035 under minimal, expected, and maximum impact conditions. Drawdowns generally were small for most of the Island (less than $10 \mathrm{ft}$ ) for the minimal and expected impact scenarios, and were larger for the maximum impact scenario. No saltwater intrusion was evident in any scenario by the year 2035.

The simulated direction of flow in the QA3 aquifer partially reversed direction in the central western area of the Island from its predevelopment west to east direction to an east to west direction under 2008 conditions. Simulated flow in this aquifer completely reversed to an east to west direction across Bainbridge Island under the maximum impact scenario, indicating a strong potential for future saltwater intrusion along the eastern and northern coastlines under continued exposure to maximum stressors.

The model was used to simulate any potential benefit to the city's wells by the protection and conservation of identified recharge areas. No development slated in any of the future scenarios occurred in the recharge areas identified by MODPATH via particle tracking as the source of the bulk of recharge to the city's wells. Therefore, the amount of drawdown in the aquifers was the same in the recharge area conservation scenario as in the expected impact scenario. 


\section{Acknowledgments}

The authors acknowledge the extensive help provided to the project by Jalyn Cummings, Cami Apfelbeck, Steve Morse, and others on the City of Bainbridge Island staff for collecting monthly water-level data and surveying well elevations, measuring streamflows, compiling wateruse information, and developing necessary data for the simulations. Numerous private well owners allowed access to their property for water-level measurements in their wells. Charles Krumheuer of the City of Bainbridge Island Water Utility and Martin Sebren of the Kitsap Public Utility District (PUD) provided water-level and water-use information for city and PUD wells. Many water purveyors on the Kitsap Peninsula including North Perry Water District, Silverdale Water District, West Sound Utility District, and the cities of Poulsbo, Bremerton, and Port Orchard provided information regarding water use.

\section{References Cited}

Bauer, H.H., and Mastin, M.C., 1997, Recharge from precipitation in three small glacial-till-mantled catchments in the Puget Sound lowland, Washington: U.S. Geological Survey Water-Resources Investigations Report 96-4219, $119 \mathrm{p}$.

Bauer, H.H., and Vaccaro, J.J., 1987, Documentation of a deep percolation model for estimating ground-water recharge: U.S. Geological Survey Open-File Report 86-536, 180 p.

Bear, Jacob, 1979, Hydraulics of groundwater: New York, McGraw-Hill, 569 p.

Bidlake, W.R., and Payne, K.L., 2001, Estimating recharge to ground water from precipitation at Naval Submarine Base Bangor and vicinity, Kitsap County, Washington: U.S. Geological Survey Water-Resources Investigations Report 2001-4110, 33 p.

Bredehoeft, J.D., Papadopulos, S.S., and Cooper, H.H., Jr., 1982, Groundwater-The water-budget myth, in Geophysics Study Committee, eds., Scientific basis of water-resource management: National Academy Press, p. 51-57.

City of Bainbridge Island, 2004, Comprehensive plan, Bainbridge Island, Wash: City of Bainbridge Island website, accessed January 10, 2011, at http://www.ci.bainbridge-isl. wa.us/comprehensive_plan.aspx.
City of Bainbridge Island, 2009, Ground water numerical model, initial scenario selection report, September 30, 2009: City of Bainbridge Island, Wash., 20 p., accessed January 10, 2011, at http://www.ci.bainbridge-isl.wa.us/ documents/pw/gw/ground water numerical model initial scenario rpt1.pdf.

Climate Impacts Group, 2010, Climate science in the public interest: University of Washington website, accessed January 2010, at http://cses.washington.edu/cig/.

Deeter, J.D., 1979, Quaternary geology and stratigraphy of Kitsap County, Washington: Bellingham, Wash., Western Washington University, M.S. Thesis, 175 p.

de Marsily, Ghislain, Lavedan, G., Boucher, M., and Fasanino, G., 1984, Interpretation of interference tests in a well field using geostatistical techniques to fit the permeability distribution in a reservoir model, in Verly, George, and others, eds., Geostatistics for natural resources characterization, Part 2: D. Reidel Publishing Company, p. 831-849.

Dion, N.P., Olsen, T.D., and Payne, K.L., 1988, Preliminary evaluation of the ground-water resources of Bainbridge Island, Kitsap County, Washington: U.S. Geological Survey Water-Resources Investigations Report 87-4237, 82 p.

Doherty, John, 2003, Ground water model calibration using pilot points and regularization: Ground Water, v. 41, no. 2, p. $170-177$.

Doherty, John, 2005, PEST, model independent parameter estimation user manual (5th ed.): Brisbane, Queensland, Australia, Watermark Numerical Computing, 336 p.

Drost. B.W., 2005, Quality-assurance plan for ground-water activities, U.S. Geological Survey, Washington Water Science Center: U.S. Geological Survey Open-File Report 2005-1126, 27 p.

Ferris, J.G., Knowles, D.B., Brown, R.H., and Stallman, R.W., 1962, Theory of aquifer tests: U.S. Geological Survey Water-Supply Paper 1536-E, 174 p.

Fetter, C.W., 1994, Applied hydrogeology, Third edition: Prentice Hall, 691 p.

Finlayson D.P., 2005, Combined bathymetry and topography of the Puget Lowland, Washington State: University of Washington website, accessed January 10, 2011, at http:// www.ocean.washington.edu/data/pugetsound/.

Freeze, R.A., and Cherry, J.A., 1979, Groundwater: Englewood Cliffs, N.J., Prentice-Hall, 604 p. 
Fulmer, C.V., 1975, Stratigraphy and paleontology of the type Blakeley and Blakely Harbor formations, in Weaver, D.W., Hornaday, G.R., and Tipton, A., eds., Paleogene symposium and selected technical papers; conference on future energy horizons of the Pacific Coast, American Association of Petroleum Geologists, Pacific Section, p. 210-271.

Garling, M.E., Molenaar, Dee, and others, 1965, Water resources and geology of the Kitsap Peninsula and certain adjacent islands: Olympia, Wash., Washington Division Water Resources, Water Supply Bulletin 18, 309 p. (Also available at http://www.ecy.wa.gov/programs/eap/wsb/pdfs/ WSB 18 Book.pdf.)

Guo, Weixing, and Langevin, C.D., 2002, User's Guide to SEAWAT: A computer program for simulation of three-dimensional variable-density ground-water flow: U.S. Geological Survey Techniques of Water-Resources Investigations, book 6, chap. A7, 77 p.

Hansen, A.J., and Bolke, E.L., 1980, Ground-water availability on the Kitsap Peninsula, Washington: U.S. Geological Survey Water-Resources Investigations Open-File Report 80-1186, 65 p.

Harbaugh, A.W., Banta, E.R., Hill, M.C., and McDonald, M.G., 2000, MODFLOW-2000, the U.S. Geological Survey Modular Ground-Water Model-User guide to modularization concepts and the ground-water flow process: U.S. Geological Survey Open-File Report 00-92, 121 p.

Haugerud, Ralph, 2005, Preliminary geologic map of Bainbridge Island, Washington: U.S. Geological Survey Open-File Report 2005-1387, 1 pl.

Heath, R.C., 1993, Basic ground-water hydrology (7th printing): U.S. Geological Survey Water-Supply Paper 2220, 84 p.

Jones, M.A., 1999, Geologic framework for the Puget Sound aquifer system, Washington and British Columbia: U.S. Geological Survey Professional Paper 1424-C, 31 p.

Kahle, S.C., 1998, Hydrogeology of Naval Submarine Base Bangor and vicinity, Kitsap County, Washington: U.S. Geological Survey Water-Resources Investigations Report 97-4060, 107 p.

Kato and Warren, Inc., and Robinson and Noble, Inc., 2000, City of Bainbridge Island, level II assessment, an element of the water resource study: State of Washington, variously paginated, accessed January 10, 2011, at http://www.kpud. org/water/reference/docs/bainbridgeisland/Bainbridge $\% 20$ Island\%20Level\%20II\%20Assessment.pdf.

Kitsap County Ground Water Advisory Committee, Economic and Engineering Services, Inc., Hart
Crowser Inc., Pacific Groundwater Group, and Robinson and Noble, Inc., 1991, Kitsap County ground water management plan, Grant no. 1, Background data collection and management issues: Olympia, Wash., Economic and Engineering Services, Inc., 2 v.

Kuniansky, E.L., Gomez-Gomez, Fernando, and TorresGonzalez, Sigfredo, 2004, Effects of aquifer development and changes in irrigation practices on ground-water availability in the Santa Isabel area, Puerto Rico: U.S. Geological Survey Water-Resources Investigations Report 03-4303, 65 p. (Also available at http://pubs.usgs.gov/wri/ wri034303/.)

Langevin, C.D., Shoemaker, W.B., and Guo, Weixing, 2003, MODFLOW-2000, the U.S. Geological Survey modular ground-water model-Documentation of the SEAWAT-2000 Version with the variable-density flow process (VDF) and the integrated MT3DMS transport process (IMT): U.S. Geological Survey Open-File Report 03-426, 43 p.

Langevin, C.D., Thorne, D.T., Jr., Dausman, A.M., Sukop, M.C., and Guo, Weixing, 2007, SEAWAT version 4-A computer program for simulation of multi-species solute and heat transport: U.S. Geological Survey Techniques and Methods, book 6, chap. A22, 39 p. (Also available at http:// pubs.usgs.gov/tm/tm6a22/.)

LaVenue, A.M., and Pickens, J.F., 1992, Application of a coupled adjoint sensitivity and kriging approach to calibrate a groundwater flow model: Water Resources Research, v. 28, no. 6, p. 1543-1569.

McDonald, M.G. and Harbaugh, A.W., 1988, A modular threedimensional finite-difference ground-water flow model: U.S. Geological Survey Techniques of Water-Resources Investigations, Book 6, Chapter Al, 586 p.

Orr, L.A., Bauer, H.H., and Wayenberg, J.A., 2002, Estimates of ground-water recharge from precipitation to glacialdeposit and bedrock aquifers on Lopez, San Juan, Orcas, and Shaw Islands, San Juan County, Washington: U.S. Geological Survey Water-Resources Investigations Report 02-4114, 114 p. (Also available at http://pubs.usgs.gov/wri/ wri024114/.)

Petkewich, M.D., and Campbell, B.G., 2007, Hydrogeology and simulation of ground-water flow near Mount Pleasant, South Carolina_-Predevelopment, 2004, and predicted scenarios for 2030: U.S. Geological Survey Scientific Investigations Report 2007-5126, 79 p.

Pollock, D.W., 1994, User's Guide for MODPATH/ MODPATH-PLOT, version 3-A particle tracking postprocessing package for MODFLOW, the U.S. Geological Survey finite-difference ground-water flow model: U.S. Geological Survey Open-File Report 94-464, variously paginated. 
Puget Sound LiDAR Consortium, 2000, PSLC 2000-Bare Earth LiDAR DEM: Puget Sound LiDAR Consortium website accessed September 20, 2007, at http:// pugetsoundlidar.ess.washington.edu.

Puget Sound Regional Council, 2006, Population, households, and employment forecast, version 2006: Puget Sound Regional Council website accessed May 17, 2010, at http:// www.psrc.org/data/forecasts/saf/.

Rantz, S.E., and others, 1982, Measurement and computation of streamflow, volume 1-Measurement of stage and discharge: U.S. Geological Survey Water-Supply Paper 2175, 284 p. (Also available at http://pubs.usgs.gov/wsp/ wsp2175/.)

Sapik, D.B., Bortleson, G.C., Drost, B.W., Jones, M.A., and Prych, E.A., 1988, Ground-water resources and simulation of flow in aquifers containing freshwater and seawater, Island County, Washington: U.S. Geological Survey WaterResources Investigations Report 87-4182, 67 p.

Sceva, J.E., 1957, Geology and ground-water resources of Kitsap County, Washington: U.S. Geological Survey Water Supply Paper 1413, 178 p.

Sloto, R.A., and Crouse, M.Y., 1996, HYSEP_-A computer program for streamflow hydrograph separation and analysis: U.S. Geological Survey Water-Resources Investigations Report 96-4040, 46 p.

Sumioka, S.S., and Bauer, H.H., 2003, Estimating groundwater recharge from precipitation on Whidbey and Camano Islands, Island County, Washington: U.S. Geological Survey Water-Resources Investigations Report 03-4101, version 1.20, August 2004, 49 p. (Also available at http://pubs.usgs. gov/wri/wri034101/.)

Theis, C.V., 1940, The source of water derived from wells: Civil Engineering, v. 10, no. 5, p. 277-280.

Thomas, B.E., Wilkinson, J.M., and Embrey, S.S., 1997, The ground-water system and ground-water quality in western Snohomish County, Washington: U.S. Geological Survey Water-Resources Investigations Report 96-4312, 218 p.
Thomas, B.E., Goodman, L.A., and Olsen, T.D., 1999, Hydrogeologic assessment of the Sequim-Dungeness area, Clallam County, Washington: U.S. Geological Survey Water-Resources Investigations Report 99-4048, 165 p.

Todd, D.K., 1980, Groundwater hydrology: New York, John Wiley and Sons, 535 p.

Troutman, B.M., 1985, Errors and parameter estimation in precipitation-runoff modeling 2-Case study: Water Resources Research, v. 21, no. 8, p. 1214-1222.

U.S. Department of Agriculture, 2004, Soil Survey Geographic (SSURGO) Database for Kitsap County, Washington: U.S. Department of Agriculture, Natural Resources Conservation Service website, accessed August 2009 at http://soils.usda. gov/survey/geography/ssurgo/.

U.S. Department of the Interior, 2008, Multi-resolution land characteristics onsortium (MRLC), area_1_landcover. zip: U.S. Department of the Interior website, accessed January 16, 2009, at http://www.mrlc.gov/multizone download.php?zone=1.

Vaccaro, J.J., Hansen, A.J., Jr., and Jones, M.A., 1998, Hydrogeologic framework of the Puget Sound aquifer system, Washington and British Columbia: U.S. Geological Survey Professional Paper 1424-D, 77 p.

Weaver, C.E., 1916, The Tertiary formations of western Washington: Washington State Geological Survey, v. 13, 319 p.

Zheng, Chunmiao, and Wang, P.P., 1999, MT3DMS-A modular three-dimensional multispecies transport model for simulation of advection, dispersion and chemical reactions of contaminants in ground-water systems; documentation and user's guide: U.S. Army Corps of Engineers Contract Report SERDP-99-1. 


\section{Glossary}

aquifer Rock or sediment that is saturated and sufficiently permeable to transmit usable quantities of water to wells or springs.

aquifer, confined An aquifer in which there are no confining beds between the zone of saturation and the land surface. There will be a water table in an unconfined aquifer.

base flow The part of stream discharge derived from groundwater seeping into the stream.

confining bed A body of rock or sediment of low hydraulic conductivity that is adjacent to one or more aquifers.

discharge The volume of water flowing in a stream or through an aquifer past a specific point in a given period of time.

hydraulic conductivity A coefficient of proportionality describing the rate at which water can move through a permeable medium such as an aquifer or confining bed. numerical flow model A model of groundwater flow in which the aquifer system is described by numerical equations, with specified values for boundary conditions, which are solved on a computer.

porosity The ratio of the volume of void spaces in a rock or sediment to the total volume of the rock or sediment.

specific yield The ratio of the volume of water sediment will yield by gravity drainage to the volume of the sediment.

specific storage The amount of water released from or taken into storage per unit volume of a sediment per unit change in head.

storativity or storage coefficient The volume of water an aquifer releases from or takes into storage per unit surface area of the aquifer per unit change in head. It is equal to the product of specific storage and aquifer thickness for a confined aquifer. In an unconfined aquifer, the storativity is equal to the specific yield. 
Publishing support provided by the U.S. Geological Survey

Publishing Network, Tacoma Publishing Service Center

For more information concerning the research in this report, contact the Director, Washington Water Science Center

U.S. Geological Survey

934 Broadway, Suite 300

Tacoma, Washington 98402

http://wa.water.usgs.gov 

造

꽁

을

움

용

종

흘

옹

을

吾

홍.

㖺

글

음



.

홈

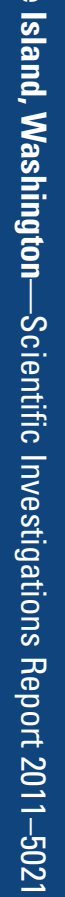

